\title{
Conceptualizing Concepcion: The Continuing Viability of Arbitration Regulations
}

\author{
Arpan A. Sura and Robert A. DeRise*
}

\begin{abstract}
Section 2 of the Federal Arbitration Act (FAA) provides that arbitration agreements "shall be valid, irrevocable, and enforceable, save upon such grounds as exist at law or in equity for the revocation of any contract." In AT\&T Mobility LLC v. Concepcion, a sharply divided Supreme Court held that the FAA preempted a California unconscionability rule that effectively guaranteed plaintiffs the right to class action arbitrations. A controversial decision, Concepcion has left courts and litigants uncertain about whether longstanding state and federal regulations on the arbitration process remain viable. To take but a few examples, may the drafter of an adhesive contract have limitless discretion to select the arbitrators unilaterally, or eliminate all of a plaintiff's rights to discovery? State and federal courts have traditionally not permitted such behavior. But to date there has been no systematic analysis of the impact of the Concepcion Court's expansive reasoning on such regulations.
\end{abstract}

This Article fills that void. We argue that Concepcion has entrenched, and in many ways rewritten, the fundamental principles of arbitration jurisprudence. What made Concepcion a bellwether was not its narrow holding on class actions, but rather its unprecedented analysis of when and how the FAA trumps other laws. In earlier opinions, the Court had suggested that the FAA would trump rules that were not "generally applicable" but instead were applied to discriminate against arbitra-

\footnotetext{
* Arpan Sura is Litigation Counsel at Sprint Corporation; Robert DeRise is an Associate at Arnold \& Porter LLP. We wrote and submitted this Article for publication prior to starting at our current jobs. The views expressed in this Article are solely our own, and do not necessarily reflect the views of our current or past employers or our clients. We thank Professor Kelli Alces, Professor Hiro Aragaki, Professor Myriam Giles, David Holman, Professor David O. Horton, Will Louden, Christian Miller, Kirstin O'Connor, Ruchit Shah, David Tyler, and Tom Jacob for their perceptive thoughts, comments and suggestions. We are also very grateful to the editors of the Kansas Law Review for their significant efforts, as a result of which this Article is much improved. Most importantly, we thank our wives, Jessica Sura and Brittany DeRise, for their unwavering encouragement and patience throughout this multi-year endeavor. All errors and shortcomings are our own. This Article is dedicated to Atlas. (c) 2013.
} 
tion. But in Concepcion, the Court devised a new test that held that the California rule was preempted because it conflicted with the "fundamental attributes of arbitration"-informality, efficiency, reduced costs, and speed.

We argue that the Court's newly-minted preemption analysis, based on abstractions about arbitration's "fundamental attributes," threatens to jeopardize a bevy of facially neutral contract laws as they are applied to arbitration agreements. In formalizing what arbitration is and why it is important, Concepcion has upended decades of statutory and common law that may interfere with arbitration's "fundamental attributes." The Supreme Court's recent decision in American Express v. Italian Colors Restaurant has only confirmed that many restrictions on arbitration, whether based in state or federal law, may now be susceptible to preemption challenges. This Article describes how the Court arrived upon this precipice, shows how going overtaking Concepcion's reasoning to its logical conclusion-disrupts a longstanding body of law, and discusses the future of arbitration regulations following the post-Concepcion cliff.

\section{INTRODUCTION}

Americans routinely sign standard form contracts that include arbitration clauses. ${ }^{1}$ The drafters, repeat institutional players like large businesses and employers, face significant exposure to litigation and prefer arbitration for a multitude of reasons, including informality and efficien$\mathrm{cy}^{2}$ But a natural question emerges from a drafter's unilateral control

1. A 2008 study, for example, concluded that seventy-five percent of consumer contracts that the authors studied, including those of Fortune 100 telecommunications, credit, and financial services companies, contained mandatory arbitration clauses. Theodore Eisenberg et al., Arbitration's Summer Soldiers: An Empirical Study of Arbitration Clauses in Consumer and Nonconsumer Contracts, 41 U. MiCH. J.L. REFORM 871, 882-83 (2008). By contrast, a study just ten years earlier showed that only 17.4 percent of consumer rights disputes were resolved by arbitration. DAVID P. Lipsky \& Ronald L. SEeber, THE APPROPRiate Resolution of CoRPorate Disputes: A RePORT ON THE GROWING USE OF ADR BY U.S. CORPORATIONS 11 (1998), available at http://digitalcommons.ilr.cornell.edu/cgi/viewcontent.cgi?article=1003\&context=icrpubs.

2. See, e.g., LIPSKY \& SEEBER, supra note 1, at 17 (finding speed and cost-savings were the top two reasons Fortune 100 companies chose arbitration and mediation); Will Pryor, Alternative Dispute Resolution, 61 SMU L. REV. 519, 522 (2008) (writing that, in the 1980s, "[p]roduct manufacturers, homebuilders, banks, insurers, employers, landlords, and in short, anyone with a concern that litigation was just too expensive and too inefficient, began to turn to arbitration as a means of controlling litigation costs and limiting exposure"); Michael Satz, Mandatory Binding Arbitration: Our Legal History Demands Balanced Reform, 44 IDAHO L. REV. 19, 34 (2007) (stating that "the 
over a contract's terms: just how one-sided can these arbitration agreements be? What limits - if any - can state and federal law impose on the arbitration process?

Consider the case of Annette Phillips, a bartender at a Hooters restaurant in Myrtle Beach, South Carolina. Claiming that she was the victim of sexual harassment, Phillips sued Hooters under the federal labor laws. ${ }^{3}$ However, Phillips had unwittingly signed an arbitration agreement with her employer that was unanimously panned as an affront to due process. ${ }^{4}$

Hooters had drafted an arbitration agreement that gave itself virtually unconstrained power over every facet of the arbitration. For instance, Hooters enjoyed limitless discretion over the pool of potential arbitrators-only those pre-approved by Hooters could hear Phillips's claim, and Hooters could even limit the pool to those with financial or family ties to the company. ${ }^{5}$ The Society of Professionals in Dispute Resolution said that "[i]t would be hard to imagine a more unfair method of selecting a panel of arbitrators." 6 Nor did the arbitration agreement contain any hint of reciprocity. ${ }^{7}$ Hooters alone had the power to move for summary dismissal or to vacate an arbitration award. Phillips had no such rights. ${ }^{8}$ By contrast, Phillips was required to provide exacting notice of her legal claims, factual allegations, and witnesses, while Hooters had no such obligations. And, as if those terms were not egregious enough, Hooters could modify the foregoing rules at any time-without prior notice. ${ }^{9}$ Fortunately for Phillips, a unanimous Fourth Circuit panel struck down the arbitration agreement, noting that it was "utterly lacking in the rudiments of even-handedness." 10

Although courts - like the Fourth Circuit in Hooters - have refused to enforce certain arbitration agreements, their authority to do so is limited by federal law. Notably, Section 2 of the Federal Arbitration Act (FAA) provides that arbitration agreements "shall be valid, irrevocable, and enforceable, save upon such grounds as exist at law or in equity for

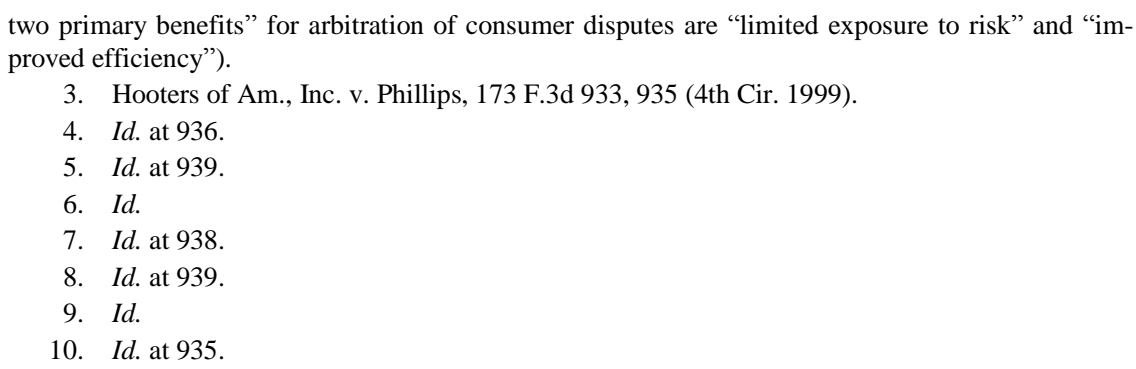


the revocation of any contract." "This is the "primary substantive provision" of the FAA. ${ }^{12}$

The FAA preempts conflicting state laws, whether passed by a legislature or given effect by a state court. ${ }^{13}$ This is a principle upon which all can agree. For some time, the Supreme Court did not have an established analytical framework to govern potential conflicts between state laws and the FAA. The Court eventually settled on "obstacle preemption" as its mode of analysis, asking at the broadest level whether a challenged state law " "interferes with the methods by which the federal statute was designed to reach [its] goal.","14

In past FAA preemption decisions, the Court suggested that a state law would be preempted by the FAA if it (1) prohibited arbitration outright, ${ }^{15}$ (2) targeted arbitration agreements for suspect treatment, ${ }^{16}$ or (3) interfered with the FAA's purposes. ${ }^{17}$ But the Court's opinions offered divergent explications of those purposes. The Court has written that "[t]he FAA reflects the fundamental principle that arbitration is a matter of contract." 18 Elsewhere, the Court explained that the FAA reflected "a liberal federal policy favoring arbitration agreements." 19 On other occasions, the Court indicated that Congress intended for Section 2 to "reverse the longstanding judicial hostility to arbitration agreements that had existed at English common law and had been adopted by American courts, and to place arbitration agreements upon the same footing as other contracts." 20 Finally, the Court recently mentioned, but never thoroughly articulated, the theory that the FAA was intended to promote a quick and efficient resolution of private disputes. ${ }^{21}$

\footnotetext{
11. 9 U.S.C. $\S 2$ (2006).

12. Moses H. Cone Mem'1 Hosp. v. Mercury Constr. Corp., 460 U.S. 1, 24 (1983).

13. See infra Part I.A.1.a.

14. Gade v. Nat'l Solid Wastes Mgmt. Ass'n, 505 U.S. 88, 103 (1992) (quoting Int'l Paper Co. v. Ouellette, 479 U.S. 481, 494 (1987)) (noting that generally courts preempt state laws that interfere with the purposes and goals of federal laws).

15. See infra Part I.A.1.a.

16. See Stephen J. Ware, Arbitration and Unconscionability After Doctor's Associates, Inc. v. Casarotto, 31 WAKE Forest L. ReV. 1001, 1012 (Winter 1996) (citing Doctor's Assocs., Inc. v. Casarotto, 517 U.S. 681, 687 (1996)) ("Any law that singles out arbitration agreements by making them less enforceable than other contracts is preempted by the FAA."); see infra Part I.A.1.b.

17. See, e.g., Preston v. Ferrer, 552 U.S. 346, 357-58 (2008); see infra Part I.A.1.c.

18. Rent-A-Center, W., Inc. v. Jackson, 130 S. Ct. 2772, 2776 (2010).

19. Moses H. Cone Mem'l Hosp. v. Mercury Constr. Corp., 460 U.S. 1, 24 (1983).

20. Gilmer v. Interstate/Johnson Lane Corp., 500 U.S. 20, 24 (1991).

21. See Preston, 552 U.S. at 353 (noting that "Congress[ional] intent [was] 'to move the parties to an arbitrable dispute out of court and into arbitration as quickly and easily as possible" and that "[a] prime objective of an agreement to arbitrate is to achieve 'streamlined proceedings and expedi-
} 
Built into this multi-pronged analysis was the flexibility to allow lower courts to invalidate a number of statutory and common law regulations on arbitration that improperly curtailed arbitration, while applying generally applicable laws to protect draftees from arbitration agreements that violate longstanding public policies. Thus, courts calibrated preemption doctrine to try to balance between a federal pro-arbitration policy with the policy of nondiscriminatory state laws intended to ensure procedural fairness.

But that precarious balance may be at an end. In AT\&T Mobility $L L C v$. Concepcion, ${ }^{22}$ a sharply divided Supreme Court held that the FAA preempted a California common law rule that effectively guaranteed the right to class action arbitration (the Discover Bank rule). ${ }^{23}$ In Discover Bank, the California Supreme Court held that certain arbitration agreements waiving class action arbitrations were unconscionable under state law, ${ }^{24}$ after which the California courts frequently invalidated waivers of class action arbitrations. ${ }^{25}$ The Concepcion majority held that the FAA preempted the Discover Bank rule because it stood as an obstacle to the pro-arbitration purposes of the FAA. ${ }^{26}$ A deeply controversial opinion, ${ }^{27}$ Concepcion has rekindled familiar debates on the merits of class

tious results",).

22. 131 S. Ct. 1740 (2011).

23. See Discover Bank v. Superior Court, 113 P.3d 1100, 1110 (Cal. 2005).

24. See id. (invalidating waivers of class action arbitration that provided the party with superior bargaining power an exemption "ffrom responsibility for [its] own fraud, or willful injury to the person or property of another"').

25. See, e.g., Cohen v. DIRECTV, Inc., 142 Cal. App. 4th 1442, 1446 (2006) (declaring an arbitration agreement unconscionable "under principles announced in Discover Bank").

26. Concepcion, $131 \mathrm{~S}$. Ct. at 1753.

27. For criticisms of Concepcion, see Megan Barnett, Comment, There is Still Hope for the Little Guy: Unconscionability is Still a Defense Against Arbitration Clauses Despite AT\&T Mobility v. Concepcion, 33 WHITTIER L. REV. 651 (2012) (generally pointing out how plaintiffs can still use unconscionability to get out of a contract's arbitration terms); David Horton, Unconscionability Wars, 106 Nw. U. L. REV. 387, 390 (2012) (arguing, among other things, that the "anti-court theory," as espoused in Concepcion, "is impossible to square with the FAA"). For a thoughtful analysis of the impact of Concepcion and lower courts' interpretations of that decision to class proceedings, see Jean Sternlight, Tsunami: AT\&T Mobility LLC v. Concepcion Impedes Access to Justice, 90 OR. L. REV. 703, 727 (2012) (arguing that Concepcion "has caused a tsunami wave that is threatening to eliminate many consumers' and employees' abilities to enforce their substantive rights by participating in class actions"). For other discussions of Concepcion, see generally David Horton, Federal Arbitration Act Preemption: Purposivism and State Public Policy, 101 GEO. L.J. 1217 (2013) (discussing the impact of Concepcion on FAA preemption analysis) [hereinafter Horton, Federal Arbitration Act Preemption]; Hiro Aragaki, AT\&T Mobility LLC v. Concepcion and the Antidiscrimination Theory of Federal Arbitration Act Preemption, 4 Y.B. ARB. \& Mediation 39 (2013) (discussing the potential implications of the majority's reasoning in Concepcion); Myriam Gilles \& Gary Friedman, After Class: Litigation in the Wake of AT\&T Mobility v. Concepcion, 79 U. CHI. L. REV. 623 (2012) (discussing Concepcion's impact on the tradition of private involvement in the en- 
actions and the desirability of consumer arbitration. ${ }^{28}$

Courts are fractured about how expansively to read Concepcion. ${ }^{29}$ And as courts struggle to determine an elusive limit to its reasoning, to date there has been no systematic analysis of the decision's proximate impact on the myriad of longstanding state and federal regulations that affect the arbitration process. This Article fills that void. We argue that Concepcion has entrenched - and in many ways rewritten - the fundamental principles of arbitration jurisprudence. Concepcion has had and will continue to have a revolutionary effect on the continuing viability of state and federal arbitration regulations.

What made Concepcion a bellwether was not its narrow holding regarding the viability of class action arbitrations, but rather its unprecedented analysis of when and how the FAA trumps other laws. Concepcion devised a new test under which the FAA preempted the California rule because it conflicted with the "fundamental attributes of arbitration": informality, efficiency, reduced costs, and speed. ${ }^{30}$ We argue that the Supreme Court's newly-minted preemption analysis, based on abstractions about arbitration's essential purposes, threatens to jeopardize a bevy of facially neutral contract laws as they are applied to arbitration agreements. And although courts initially tried to discern a bright-line limiting principle to Concepcion's reasoning, just this term the Supreme Court provided a resounding affirmation of Concepcion's expansive reach in American Express Co. v. Italian Colors Restaurant. ${ }^{31}$ In formalizing what arbitration is and why it is important, Concepcion has upended decades of statutory and common law.

This Article shows how, and it does so in three parts. Part I discusses how the FAA previously coexisted with state and federal regulations and describes how Concepcion marks a significant break from precedent. This part discusses Concepcion's broad and narrow holdings, a distinction to which courts often have not been sensitive. Part II analyzes state regulations on the arbitration process (whether imposed by statute or common law), many of which are suddenly vulnerable in light of Con-

forcement of public laws).

28. See, e.g., Robin Sidel, No Day in Court for Bank Clients, Wall St. J., Aug. 2, 2011, http://online.wsj.com/article/SB10001424053111904292504576482603037174400.html (discussing the debate over the use of mandatory arbitration clauses in consumer deposit account agreements in the wake of Concepcion).

29. See infra notes 125-282 and accompanying text (discussing various interpretations of Concepcion).

30. Concepcion, 131 S. Ct. at 1748.

31. 133 S. Ct. 2304 (2013). 
cepcion. Open questions include whether the FAA preempts:

- Rules regulating procedure

- Rules regulating certain interlocutory appeals

- Rules requiring a baseline entitlement to discovery

- Rules prohibiting confidential arbitration proceedings

- Rules regulating the division of arbitration costs

- Rules prohibiting arbitration in far-flung jurisdictions

- Any decision based on common law unconscionability principles

We discuss the likely impact of Concepcion on these state rules, which are already proving to be the next battleground of FAA preemption jurisprudence. It will be critical for courts and litigants to be aware of Concepcion's dramatic effect in this area.

Part III turns to federal regulations. Although not technically within the sphere of Concepcion's preemption holding, federal laws implicating arbitration also have been drawn into the firefight because they may conflict with the FAA's "fundamental attributes" just as readily as state laws do. The quickly evolving nature of this field is apparent. In American Express, the Court considered whether the FAA - and Concepcion in particular-permits courts invoking the "federal substantive law of arbitrability" ${ }^{\prime 2}$ to invalidate arbitration agreements on the ground that they do not permit class action arbitration of a federal law claim. ${ }^{33}$ Relying in large part on Concepcion, the Court enforced the class action waiver even though the cost of individual arbitration of a federal antitrust claim would far exceed any potential recovery. ${ }^{34}$ We discuss the implications of Concepcion and American Express on the federal common law in this and other contexts.

In sum, this Article tries to make sense of the potentially boundless reach of Concepcion. It is not intended to serve as a policy-based criticism or a suggestion that the decision be overruled. ${ }^{35}$ Rather, this Article is intended to give courts and commentators much-needed guidance on the future of traditional regulations on the arbitration process. We con-

32. In re Am. Express Merchs.' Litig., 554 F.3d 300, 312 (2d Cir. 2009), cert. granted, judgment vacated sub nom., Am. Express Co. v. Italian Colors Rest., 130 S. Ct. 2401 (2010), rev'd, 133 S. Ct. 2304 (2013).

33. See Am. Express Co., 133 S. Ct. at 2310.

34. See id. at 2311-12.

35. For such criticisms, see supra note 27. 
clude that state and federal public policies that attempt to curb the excesses of arbitration agreements, even those applied in the Hooters case, are suddenly vulnerable. And the Court's recent decision in American Express only underscores their vulnerability. The remainder of this Article discusses how that happened and what it means.

\section{CONCEPCION AND ITS PREDECESSORS}

\section{A. FAA Conflicts Before Concepcion}

The FAA has an uneasy relationship with numerous state and federal laws, which frequently leads to potential or actual conflicts. It provides that parties may choose to arbitrate their disputes, and claims arising under state and federal law generally may be resolved by arbitration. This means that parties can, by contract, shape an alternative process to resolve disputes which is often vastly different from most court systems, and which exists largely outside their purview. In many, if not most instances, however, state legislatures and Congress pass laws without considering the possibility that they will be at issue in arbitration as well as in court. For example, laws establishing the process for bringing certain claims or remedies are a particularly fertile ground for preemption issues. ${ }^{36}$ Because there are critical distinctions for analyzing conflicts between state and federal law, as opposed to conflicts solely among federal statutes, this section briefly addresses the development of the Court's FAA jurisprudence in both of these areas.

By way of background, Section 2 of the FAA is comprised of two clauses. ${ }^{37}$ The first, which has been called the "command clause," declares that a contract "to settle by arbitration a controversy thereafter arising out of such contract ... shall be valid, irrevocable, and enforceable" under federal law. ${ }^{38}$ The second is the "savings clause," which provides a carve-out from the command clause's general rule. The savings clause says that an arbitration agreement is not "valid, irrevocable, [or]

36. See, e.g., Preston v. Ferrer, 552 U.S. 346 (holding a state law purporting to vest primary jurisdiction over a certain type of claim in a state agency notwithstanding parties' agreement to arbitrate is preempted by FAA); Mastrobuono v. Shearson Lehman Hutton, Inc., 514 U.S. 52, 63 (1995) (rejecting the argument that arbitrators were precluded from awarding punitive damages under New York arbitration law, even though parties had agreed to apply New York law in a choice of law clause).

37. 9 U.S.C. $\$ 2(2006)$.

38. Richard A. Nagareda, The Litigation-Arbitration Dichotomy Meets the Class Action, 86 NOTRE DAME L. REV. 1069, 1090 (2011). 
enforceable," when "grounds [] exist at law or in equity for the revocation of any contract." 39

Although Section 2 does not contain language expressly preempting state or federal law to the contrary, the Supreme Court has long held the provision to have preemptive effect. Long before Concepcion, the Court had confronted the issue of whether the FAA trumped various applications of state or federal law. Although the Court frequently invokes the FAA's text (particularly the savings clause) in its preemption analysis, many believe that the Court's precedent is not textualist, but instead purposivist, in nature. ${ }^{40}$ Indeed, until recently, this lack of clarity in the Court's analysis left many commentators and courts divided over the proper approach to decide whether the FAA supersedes state and federal rules. ${ }^{41}$ This part of the Article discusses that precedent-from which Concepcion represented a significant departure.

\section{FAA v. State Law}

FAA preemption doctrine before Concepcion was not a model of clarity. However, three general rules or standards could be gleaned from precedent. First, and most obviously, the FAA preempts state law that prohibits arbitration outright. Second, the FAA preempts state law that reflects hostility towards arbitration by singling it out for unequal treatment. Finally, and the least settled of the three, the FAA preempts state law that conflicts with the FAA's purposes.

The preemption analysis was rather clear-cut in the so-called "first generation" cases in which states attempted to prohibit arbitration outright. ${ }^{42}$ However, the "second generation" of arbitration regulations was subtler, frequently attempting to undermine arbitration through a thousand cuts. These laws restricted parties' recourse to arbitration, imposed restrictions on arbitration procedure, or otherwise imposed burdens on

\footnotetext{
39. 9 U.S.C. $\S 2$.

40. See, e.g., Horton, Federal Arbitration Act Preemption, supra note 27, at 1245-55.

41. See Christopher R. Drahozal, Federal Arbitration Act Preemption, 79 IND. L.J. 393, 407 n.115 (2004).

42. See id. at 393-94 (citing “'[f]irst generation' cases of FAA preemption involve state laws that invalidate parties" agreements to arbitrate" and noting that "state legislatures have begun adopting laws that modify the parties' arbitration agreement rather than invalidating it, regulating the arbitration process rather than the parties' obligation to arbitrate"); see also Hiro N. Aragaki, Equal Opportunity for Arbitration, 58 UCLA L. REV. 1189, 1200 (2011) (employing Professor Drahozal's classification for substantive laws that invalidate arbitration agreements and "result[] in the parties litigating, rather than arbitrating").
} 
the arbitration process. ${ }^{43}$ The "second generation" arbitration regulations provide the most grist for the mill for lower courts dealing with FAA preemption.

Regulations that expressly singled out arbitration for disfavored treatment could be easy to spot; however, other regulations appeared on their face to apply to all contracts, but in effect, imposed restrictions disproportionately burdening arbitration. Until recently, the Supreme Court often dodged these questions by, for example, interpreting the arbitration agreement so as to find state law inapplicable, thereby avoiding a conflict. ${ }^{44}$ While these cloaked preemption decisions (which we call "quasipreemption" cases) ${ }^{45}$ provide some degree of insight into FAA preemption analysis, no stable rule had emerged regarding the viability of second generation regulations. Nor did the quasi-preemption cases portend the Court's analysis in Concepcion. ${ }^{46}$

\section{a. Prohibits Arbitration Outright}

The first case in which the Supreme Court held that the FAA preempted state law was Southland Corp. v. Keating. ${ }^{47}$ The California Franchise Investment $\mathrm{Law}^{48}$ at issue in this case invalidated any contract term that tried to "bind any person acquiring a franchise to waive compliance with any provision of this law," ${ }^{, 49}$ which the California Supreme Court interpreted as meaning that "judicial consideration of claims brought under that statute" was required. ${ }^{50}$ The California Supreme

43. Aragaki, supra note 42, at 1200-01 (noting that second generation "does not regulate the promise to arbitrate per se but rather only procedural matters").

44. See, e.g., Volt Info. Scis., Inc. v. Bd. of Trs. of Leland Stanford Junior Univ., 489 U.S. 468, 477-78 (1989). We do not mean to suggest that state statutes attempting to keep certain classes of claims in court are a thing of the past. Recently, the Supreme Court issued a terse per curiam opinion, post-Concepcion, which summarily vacated and remanded a West Virginia decision that held on public policy and unconscionability grounds that all pre-dispute arbitration agreements with nursing homes for personal injury or wrongful death suits were unenforceable. Marmet Health Care Ctr., Inc. v. Brown, 132 S. Ct. 1201, 1204 (2012).

45. See, e.g., Volt Info. Scis., 489 U.S. at 477-78 (ordering judicial enforcement of the express terms of the contract and avoiding addressing the conflict between the FAA and a state law allowing courts to stay arbitrations); Mastrobuono v. Shearson Lehman Hutton, Inc., 514 U.S. 52, 63 (1995) (avoiding ruling on the conflict of law by finding that the parties did not intend for the state law to govern).

46. See infra Part I.A.1.c.

47. 465 U.S. 1 (1984); see also Drahozal, supra note 41, at 399.

48. 465 U.S. at 3-5.

49. CAL. CORP. CODE $\S 31512$ (West 1970).

50. Southland, 465 U.S. at 5 (emphasis added). 
Court concluded that an arbitration agreement in a franchise contract was voided by the California statute, and further, that the statute was not preempted by the FAA. ${ }^{51}$

The Supreme Court reversed the California court, holding-with minimal discussion - that the FAA preempted the Franchise Investment Law. ${ }^{52}$ According to the Court, in Section 2, Congress had "mandated the enforcement of arbitration agreements." 53 The Court also reasoned that Section 2 was a declaration of a "national policy favoring arbitration," which prohibited the states from requiring judicial resolution of claims when the parties agreed to arbitration. ${ }^{54}$ Although the Court did not clarify which preemption test governed under the FAA, i.e., express preemption, implied field preemption, etc., the Southland decision clearly turned on the fact that the Franchise Investment Law prohibited arbitration outright. ${ }^{55}$

Three years later, in Perry v. Thomas, the Court considered whether the FAA preempted a provision in the California Labor Code permitting a party to bring an action in court to collect wages "without regard to the

51. $\quad I d$

52. See id. at 16. The principal issue in Southland was whether the FAA applied in state court. See id. at 8-9. The majority held that by enacting the FAA, Congress created "a substantive rule applicable in state as well as federal courts." Id. at 16. This conclusion was subject to significant criticism by the dissent. See id. at 36 (O’Connor, J., dissenting). See, e.g., Edward Brunet, Toward Changing Models of Securities Arbitration, 62 BROOK. L. REV. 1459, 1469 n.33 (1996) ("The Southland decision is remarkable for its preemption holding that blatantly ignores legislative intent."); Paul D. Carrington \& Paul H. Haagen, Contract and Jurisdiction, 1996 SUP. CT. REV. 331, 380 ("[T]he opinion of the Court was an extraordinarily disingenuous manipulation of the history of the 1925 Act."). Turning to the Franchise Investment Law, the Court stated that "Congress intended to foreclose state legislative attempts to undercut the enforceability of arbitration agreements." Southland, 465 U.S. at 16. With this sparse analysis, the Court concluded that the Franchise Investment Law, as interpreted by the California courts to require judicial consideration of claims brought under the statute, "directly conflicts with $\S 2$ of the Federal Arbitration Act and violates the Supremacy Clause." Id. at 10.

53. Southland, 465 U.S. at 10.

54. Id.

55. Scholars appear to be divided over what preemption theory the Court applied in Southland. Compare, e.g., 1 LAURENCE H. TRIBE, AMERiCAN CONSTitutional LaW § 6-29, at 1179-80 (3d ed. 2000) (describing Southland as an impossibility preemption case), with Caleb Nelson, Preemption, 86 VA. L. REV. 225, 228 n.15 (2000) (“[The Supreme Court] made clear that even if one sovereign's law purports to give people a right to engage in conduct that the other sovereign's law purports to prohibit, the 'physical impossibility' test is not satisfied; a person could comply with both state and federal law simply by refraining from the conduct."); see also Drahozal, supra note 41, at $407 \mathrm{n} .115$ ("Academic commentators are divided, however, on whether FAA preemption is a form of impossibility preemption or whether it is a form of obstacle preemption."). Forecasting Concepcion three decades later, the defendant in Southland argued that the FAA precludes class arbitration, an issue undecided by the Court. See Southland, 465 U.S. at 17. 
existence of any private agreement to arbitrate." drew from its reasoning in Southland ${ }^{57}$ to conclude that the California law, which likewise required a judicial forum to resolve wage disputes, was "in unmistakable conflict" with the clear federal policy underlying the FAA. ${ }^{58}$ While again, the Court did not articulate the preemption theory on which it relied, the Court's decision suggested that, at the very least, a state law could not nullify the enforcement of arbitration agreements.

The Court in Perry refused to address whether the contract was adhesive and unconscionable. ${ }^{59}$ However, significantly, the Court noted that a general contract defense, "whether of legislative or judicial origin, is applicable if that law arose to govern issues concerning the validity, revocability, and enforceability of contracts generally."60 But the Court also explained that such a defense may not "rely on the uniqueness of an agreement to arbitrate as a basis for a state law holding that enforcement would be unconscionable, for this would enable the court to effect what we hold today the state legislature cannot." ${ }^{61}$ Therein lay the reasoning for an emerging second prong of the Court's preemption analysis.

\section{b. Places Arbitration on Unequal Footing}

The Supreme Court also has invalidated state laws that target arbitration for unequal treatment, apparently even if they do not necessarily impair parties' ability to form a contract or inhibit the efficiency gains of the arbitration process. The primary example of this analysis is found in Doctor's Associates, Inc. v. Casarotto, a case addressing a Montana statute that required conspicuous notice of an arbitration provision in a contract. $^{62}$ The Montana Supreme Court concluded that the notice requirement did not "undermine the goals and policies of the FAA,"63 reasoning that the law did not impair the parties' freedom to contract, and accord-

\footnotetext{
56. 482 U.S. 483,484 (1987).

57. 470 U.S. 213 (1985).

58. Perry, 482 U.S. at 491-92 (quoting Byrd, 470 U.S. at 221); see also Volt Info. Scis. Inc. v. Bd. of Trs. of the Leland Stanford Junior Univ., 489 U.S. 468, 478 (1989) ("[W]e have held that the FAA pre-empts state laws which require a judicial forum for the resolution of claims which the contracting parties agreed to resolve by arbitration." (internal quotation marks and citation omitted)).

59. Perry, 482 U.S. at 492 n.9.

60. Id. (emphasis omitted).

61. Id.

62. Mont. Code AnN. § 27-5-114(4) (1995).

63. See Doctor's Assocs., 517 U.S. at 685.
} 
ingly refused to enforce an arbitration agreement that did not provide such conspicuous notice. ${ }^{64}$

Although the Supreme Court reversed the Montana decision and invalidated the state law, it is unclear whether the Court viewed the Montana law as interfering with the text of the FAA or with its purposes. At one point, the Court stated that the Montana statute "directly conflicts" with the FAA because the statute applied a condition (the notice provision) to arbitration agreements that did not apply to contracts generally. ${ }^{65}$ Yet the Court also stated that the "goals and policies" of the FAA and the Court's precedents were "antithetical" to the Montana statute. ${ }^{66}$ Invoking the savings clause, the Court also explained that the Montana statute was "inconsonant" with the FAA because it invalidated arbitration agreements on a ground that did not "exist at law or in equity for the revocation of any contract." 67

The Doctor's Associates preemption analysis was notable because it rested solely on Montana's disparate treatment of arbitration. ${ }^{68}$ The Court did not consider whether Montana's notice provision inhibited parties' ability to enter into arbitration agreements, nor did the Court consider whether the law made arbitration slower, costlier, or less efficient. Indeed, the practical effect of the Montana statute was apparently irrelevant to the preemption analysis. Thus, the Court appears to have struck down the notice provision simply because the law per se treated arbitration agreements differently than other contracts. ${ }^{69}$

\section{c. Interferes with the FAA's Core Purpose}

The third line of cases strays farther from the FAA's text, instead asking whether the state law interferes with the FAA's goals and purposes. Cases employing this method of analysis share two interesting fea-

64. See id. at 684-85 ('Section 27-5-114(4), in the Montana court's judgment. . . did not preclude arbitration agreements altogether.").

65. Id. at 687 .

66. Id. at 688; see also id. at 683 (concluding that the Montana statute "solely" targeted arbitration contracts).

67. Id. at 688 (quoting 9 U.S.C. $\$ 2$ (2006)).

68. See, e.g., Colin P. Marks, The Irony of AT\&T v. Concepcion, 87 IND. L.J. SuPP. 31, 34 (2012) (writing that the Doctor's Associates decision "made [it] clear" that "the FAA prevents state legislatures and the judiciary from creating special rules limiting the effect of, or striking down, arbitration clauses with rules that are only applicable to arbitration clauses").

69. See Doctor's Assocs., 517 U.S. at 683 ("We hold that Montana's first-page notice requirement, which governs not 'any contract,' but specifically and solely contracts 'subject to arbitration,' conflicts with the FAA and is therefore displaced by the federal measure."). 
tures. First, this analysis requires a definition of the goals and purposes of the FAA, but the Court's decisions have not been consistent in this regard. Second, until recently, these cases did not undertake a full preemption analysis. Rather, the Court effectively avoided the difficult preemption questions by construing the arbitration agreements so as to avoid a conflict with state law. This is why we call these "quasi-preemption" cases.

The Court's first such case was Volt Information Sciences, Inc. v. Board of Trustees of Leland Stanford Junior University. ${ }^{70}$ This was the first case in which the Court discussed FAA obstacle preemption, and it was the first case to address the validity of state unconscionability law as applied to arbitration agreements. In Volt, the Court addressed an arbitration agreement with a choice-of-law clause under which any dispute was governed "by the law of the place where the Project is located," namely, California. ${ }^{71}$ The Court considered whether the California Arbitration Act, which allowed a court to stay arbitration pending resolution of related litigation, was preempted by the FAA, even though the parties ostensibly had chosen California law to govern. ${ }^{72}$

The Court in Volt determined for the first time that potential conflicts between state laws and the FAA would be resolved under the obstacle preemption framework. According to the Court, the "FAA contains no express pre-emptive provision, nor does it reflect a congressional intent to occupy the entire field of arbitration." 73 After clarifying that express and field preemption theories did not apply in the FAA context, ${ }^{74}$ the Court wrote that "state law may nonetheless be pre-empted to the extent that it actually conflicts with [the FAA] - that is, to the extent that it 'stands as an obstacle to the accomplishment and execution of the full purposes and objectives of Congress.",75 Thus, the FAA would displace the California law stay provision if it "undermine[d] the goals and poli-

\footnotetext{
70. 489 U.S. 468 (1989).

71. Id. at 470 (citation omitted).

72. Volt, 489 U.S. at 470-71; CAL. CIV. Proc. CODE $\S 1281.2$ (c) (West 2013).

73. Id. at 477 (citing Bernhardt v. Polygraphic Co. of Am., 350 U.S. 198 (1956)).

74. See, e.g., Jodi Wilson, How the Supreme Court Thwarted the Purpose of the Federal Arbitration Act, 63 CASE W. RES. L. REV. 91, 120 n.145 (2012) (noting that "the FAA has no express preemptive provision" and that "state law will only be preempted by the FAA under a conflict preemption analysis" (citing Volt, 489 U.S. at 477)); Richard C. Reuben, FAA Law, Without the Activism: What if the Bellwether Cases Were Decided by a Truly Conservative Court?, 60 U. KAN. L. REV. 883, 907-08 (2012) (noting that the FAA does not address express preemption and that the field theory of preemption is not a compelling justification).

75. Volt, 489 U.S. at 477 (quoting Hines v. Davidowitz, 312 U.S. 52, 67 (1941)).
} 
cies of the FAA.",76

The Court then held that the FAA's "primary purpose" was to promote the freedom of contract, because arbitration "is a matter of consent, not coercion, and parties are generally free to structure their arbitration agreements as they see fit." 77 The Court thereby subordinated the potential efficiency gains motivating arbitration generally and the FAA specifically: "While Congress was no doubt aware that the Act would encourage the expeditious resolution of disputes," the Court explained, "its passage "was motivated, first and foremost, by a congressional desire to enforce agreements into which parties had entered.",78 Moreover, this was not the first time that the Court elevated the other purposes of the FAA above efficiency. ${ }^{79}$

Having determined that the FAA's "primary purpose" was to honor the parties' agreement, the Court essentially ended its analysis, holding that the FAA required judicial enforcement of the express terms of the contract. ${ }^{80}$ It was immaterial to the Court's analysis that the contract would be enforced under California's state law regime, whose stay provision might inhibit the efficient resolution of disputes. The Court had deemed that its main task was to give effect to the parties' agreement, the meaning of which was an issue of state law not before the Court. Thus, California's relatively inefficient system did not conflict with the FAA. ${ }^{81}$

\footnotetext{
76. Id. at $477-78$.

77. Id. at 479 .

78. Id. at 478 (quoting Dean Witter Reynolds, Inc. v. Byrd, 470 U.S. 213, 220 (1985)).
}

79. In Dean Witter Reynolds, Inc., the Court held that the FAA "requires district courts to compel arbitration of pendent arbitrable claims when one of the parties files a motion to compel, even where the result would be the possibly inefficient maintenance of separate proceedings in different forums." 470 U.S. at 217. In support of this proposition, the Court stated:

We therefore are not persuaded by the argument that the conflict between two goals of the Arbitration Act - enforcement of private agreements and encouragement of efficient and speedy dispute resolution - must be resolved in favor of the latter in order to realize the intent of the drafters. The preeminent concern of Congress in passing the Act was to enforce private agreements into which parties had entered, and that concern requires that we rigorously enforce agreements to arbitrate, even if the result is "piecemeal" litigation, at least absent a countervailing policy manifested in another federal statute. By compelling arbitration of state-law claims, a district court successfully protects the contractual rights of the parties and their rights under the Arbitration Act.

Id. at 221 (citation omitted).

80. Volt, 489 U.S. at 478 (citing Prima Paint Corp. v. Flood \& Conklin Mfg. Co., 388 U.S. 395, 403 n.12 (1967)).

81. See id. at 479 ("Where, as here, the parties have agreed to abide by state rules of arbitration, enforcing those rules according to the terms of the agreement is fully consistent with the goals of the FAA, even if the result is that arbitration is stayed where the Act would otherwise permit it to go forward."). 
Although Volt represented the most definitive guidance on FAA preemption at the time and obstacle preemption analysis remains on firm footing today, ${ }^{82}$ the Court's decisions soon thereafter departed from other aspects of Volt's reasoning. ${ }^{83}$ Whereas Volt gave primacy to the plain language of the parties' agreement, the Court's later decisions employed other analytic presumptions, leading to results arguably inconsistent with the language of the contract.

In Mastrobuono v. Shearson Lehman Hutton, Inc., the Court determined that the parties did not really intend state arbitration law to govern. ${ }^{84}$ The contract included conflicting provisions: providing that "any controversy" would be governed by securities arbitration rules, but also that the "entire agreement" would be governed "by the laws of the State of New York." ${ }^{85}$ The arbitrator had awarded punitive damages against a securities brokerage, even though New York law precluded an award of punitive damages. ${ }^{86}$ Accordingly, the brokerage firm argued that, because the parties had ostensibly chosen New York law to govern the terms of their dispute, the award was invalid. ${ }^{87}$ While one might think that Volt would have impelled the Court to apply the provisions of New York law because the parties had chosen that law to govern the terms of their agreement, the Court in Mastrobuono distinguished Volt and applied substantive federal law, a rare result that favored the draftee. ${ }^{88}$

The Court's key move in Mastrobuono was to elevate the "federal policy favoring arbitration" into a presumption well beyond what the Court said in Volt. ${ }^{89}$ Although Volt said the FAA embodied a federal policy favoring arbitration, ${ }^{90}$ that was only true if the parties had agreed

82. See, e.g., Hiro N. Aragaki, Arbitration's Suspect Status, 159 U. PA. L. REv. 1233, 1241 \& n.37 (2011) (noting that obstacle preemption is "the way in which the Court finds FAA section 2 to 'preempt' state law").

83. Moreover, following Volt, the Court later invalidated a number of state laws as preempted by the FAA, but often did not state the theory under which they were preempted. For example, in Allied-Bruce Terminix Companies, Inc. v. Dobson, 513 U.S. 265 (1995), the Court-after deciding the main issue, that the FAA's scope extended to the full jurisdictional limits of the Commerce Clause - held that Alabama's statute, which rendered predispute arbitration agreements unenforceable, was preempted by the FAA. See id. at 281; see also Citizens Bank v. Alafabco, Inc., 539 U.S. 52,58 (2003).

84. 514 U.S. 52, 63 (1995).

85. Id. at $54-55,58-59$.

86. Id. at 53 .

87. Id. at $54-55$.

88. Id. at 58 .

89. Id. at 62.

90. Volt Info. Scis., Inc. v. Bd. of Trs. of Leland Stanford Junior Univ., 489 U.S. 468, 475 (1989). 
to arbitration in the first place. ${ }^{91}$ Properly read, Volt gave primacy to contract, not arbitration. ${ }^{92}$ But Mastrobuono flipped the premise and the conclusion, reasoning that "ambiguities as to the scope of the arbitration clause itself resolved in favor of arbitration." Applying the policy of interpreting ambiguities against the drafter, ${ }^{93}$ the Court held that the parties must have chosen federal law to govern. ${ }^{94}$ The reasoning appears circular: on one hand, the Court relied on the federal policy favoring arbitration to determine the meaning of the parties' agreement; on the other, the Court strictly enforced the agreement's meaning because the federal policy favoring arbitration required it. The Court, notably, did not decide whether a state law restricting or expanding the scope of punitive damages would have been preempted under the FAA.

The Court decided another quasi-preemption case in the context of class action arbitration. In Green Tree Financial Corp. v. Bazzle, the Court again confronted the validity of state laws that banned class action waivers, and again did not decide whether such laws were preempted. ${ }^{95}$ In Bazzle, contracts between a commercial lender and its customers were silent as to whether class action arbitrations were permissible. ${ }^{96}$ While the South Carolina Supreme Court had interpreted this silence to permit class actions, ${ }^{97}$ the Supreme Court reversed on the grounds that the arbitrator - not South Carolina courts - was the proper authority to decide whether such actions were permissible in the first instance. ${ }^{98}$

What makes Bazzle notable is its dissent. Three Justices would have found that the FAA preempted the South Carolina judicial rule permitting class arbitration based on a different construction of the agreement. ${ }^{99}$ In their view, the contract was not silent: because it referred to the consumer in the singular tense, a class action involving multiple

91. Id. at 478 (citing Southland Corp. v. Keating, 465 U.S. 1, 9-10 (1984)).

92. See id. at 476 ("There is no federal policy favoring arbitration under a certain set of procedural rules; the federal policy is simply to ensure the enforceability, according to their terms, of private agreements to arbitrate.").

93. Mastrobuono, 514 U.S. at 62.

94. Id. at 59-60; see also Nat'1 Union Fire Ins. Co. of Pittsburgh, Pa. v. Belco Petroleum Corp., 88 F.3d 129, 134 (2d Cir. 1996) (applying federal law to a contract with a similarly ambiguous arbitration clause).

95. 539 U.S. 444,452 (2003).

96. Id. at 450 .

97. Id. at 447 .

98. Id. at $451-54$.

99. Id. at 455-60 (Rehnquist, C.J., dissenting). Rehnquist's dissent was joined by Justices O'Connor and Kennedy and states that the "holding of the Supreme Court of South Carolina contravenes the terms of the contracts and is therefore pre-empted by the FAA." Id. at 455. 
plaintiffs would have exceeded the contract's plain language. ${ }^{100}$ Accordingly, to the extent that a class action expressly conflicted with the contract language, the dissent would have held that the South Carolina rule was preempted by the FAA. ${ }^{101}$ The dissent's grounds for preemption invoked Volt's reasoning about the primacy of contract enforcement. ${ }^{102}$ As it turned out, this was radically different than the justifications ultimately proffered by the Concepcion majority.

Finally, in the last quasi-preemption decision before Concepcion, the Court in Preston v. Ferrer held that when contracting parties agree to arbitrate all questions arising under a contract, the FAA preempts state laws that vest primary jurisdiction in another forum. ${ }^{103}$ The contract at issue in Ferrer was between a talent agent and a television star and it contained an arbitration provision requiring that all issues arising under the contract be arbitrated. ${ }^{104}$ California's Talent Agency Act, however, vested original jurisdiction in an administrative agency. ${ }^{105}$

The Court rejected the argument that state laws could require the exhaustion of remedies before arbitration. ${ }^{106}$ The Court offered several different reasons why the California exhaustion was inapplicable. Previewing Concepcion, the Court noted that exhaustion would frustrate the purposes of the FAA by "hinder[ing] speedy resolution of the controversy," ${ }^{, 107}$ but did not give the efficiency rationale a full-throated articulation. And indeed, the Court indicated elsewhere that California's exhaustion requirement failed under the first two prongs of FAA preemption analysis because it vested "exclusive jurisdiction to decide an issue" in a state agency "that the parties agreed to arbitrate" (prong 1), and it "impose[d] prerequisites to enforcement of an arbitration agreement that are not applicable to contracts generally" (prong 2). ${ }^{108}$

The Court distinguished Ferrer from Volt, noting that the parties did not clearly choose California law since the contract also incorporated the rules of the American Arbitration Association (AAA). ${ }^{109}$ Because Cali-

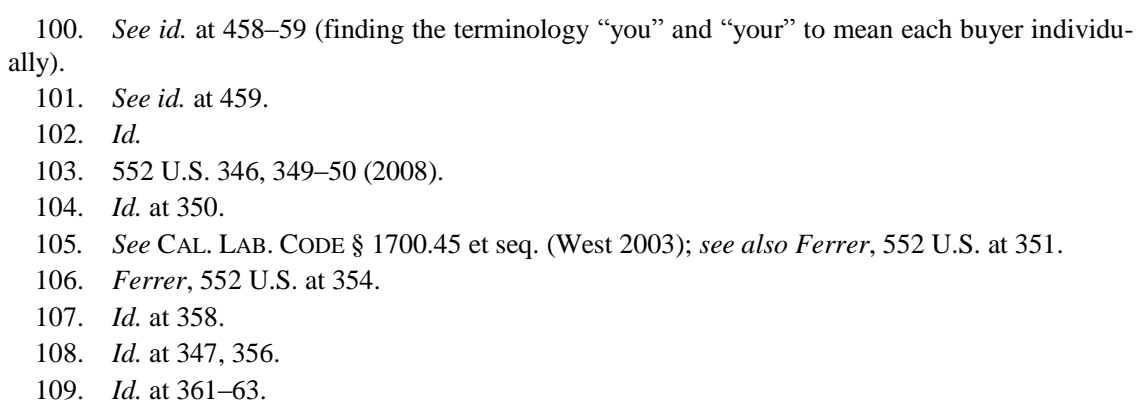


fornia's exhaustion requirement could effectively foreclose arbitration by issue and claim preclusion, the Court concluded that the parties did not select California law to require initial adjudication in the administrative agency. ${ }^{110}$ The language in Ferrer thus suggests that the Court relied on an obstacle preemption analysis at least in part to displace the California law, but the Court elided the precise question as to the FAA's purposes.

\section{FAA v. Federal Law}

There is also a body of pre-Concepcion federal common law that operates as a check on the FAA's pro-arbitration policy, known as the "vindication of statutory rights" principle. As the Supreme Court noted years earlier, Section 2 of the FAA creates "a body of federal substantive law of arbitrability, applicable to any arbitration agreement within the coverage of the Act." 111 In Mitsubishi Motors Corp. v. Soler ChryslerPlymouth, Inc., the Court held that arbitration of a federal cause of action was permissible only "so long as the prospective litigant effectively may vindicate its statutory cause of action in the arbitral forum."112 Thus, if an arbitration clause operated "as a prospective waiver of a party's right to pursue statutory remedies for antitrust violations," the Court "would have little hesitation in condemning the agreement as against public policy." 113

Over a decade later, in Green Tree Financial Corp. v. Randolph, the Court addressed the recurring, well-litigated, and yet unstable issue of cost-shifting in arbitration contracts and when an arbitration agreement can be invalidated on the grounds that arbitration would be prohibitively expensive. ${ }^{114}$ In Randolph, the parties agreed to arbitrate all claims under their contract, including claims involving statutory rights. ${ }^{115}$ However, the consumer argued that the arbitration clause was unenforceable because, by failing to mention arbitration costs and fees, it potentially subjected her to steep costs and thus prevented her from vindicating her rights under the federal Truth in Lending Act. ${ }^{116}$

The Court declined to invalidate the arbitration agreement solely be-

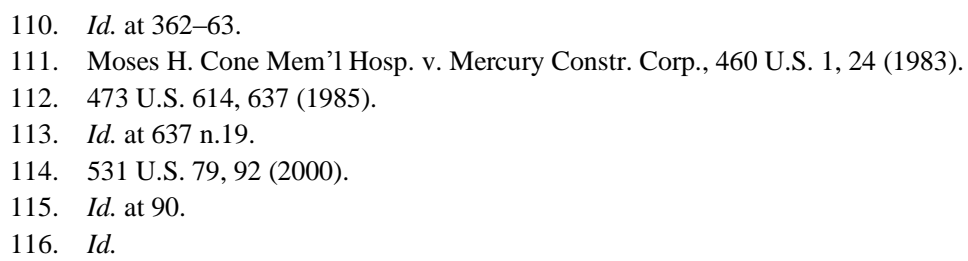


cause it was silent about costs, reasoning that doing so would subvert the federal policy favoring arbitration. ${ }^{117}$ A party trying to invalidate an arbitration agreement because of allegedly prohibitive arbitration costs had the burden of proof, the Court explained. ${ }^{118}$ In Randolph, the plaintiff did not meet that burden because she only provided speculation about her costs. Accordingly, the Court punted on the question of how much evidence would suffice to invalidate an arbitration agreement on the basis of prohibitive costs. ${ }^{119}$ Although the Court did not decide whether the FAA preempted state laws prohibiting cost shifting, many courts have adopted Randolph's reasoning in their state unconscionability analysis, the implications of which we discuss below.

\section{B. Concepcion's Narrow and Broad Holdings}

We now turn to Concepcion. Properly construed, Concepcion held that the FAA preempts a state law rule if the rule (1) prohibits outright the arbitration of a particular type of claim; ${ }^{120}(2)$ violates the FAA's anti-discrimination principle, i.e., targets arbitration for different treatment than other contracts; ${ }^{121}$ or (3) "interferes with fundamental attributes of arbitration," 122 by undermining the procedural informality that is arbitration's "principal advantage," 123 or by rendering arbitration "slower" or "more costly."124 The first two prongs of the test were clearly settled before the decision. ${ }^{125}$ The third prong, however, represents Concepcion's innovation: a standard only hinted at in the past, but now employed unreservedly despite its lack of obvious boundaries. As we discuss below, Concepcion's analysis changes slightly in the context of federal rules af-

\footnotetext{
117. Id. at 91 .

118. Id. at $91-92$

119. Id. at 92 ("How detailed the showing of prohibitive expense must be before the party seeking arbitration must come forward with contrary evidence is a matter we need not discuss; for in this case neither during discovery nor when the case was presented on the merits was there any timely showing at all on the point.").

120. AT\&T Mobility LLC v. Concepcion, 131 S. Ct. 1740, 1747 (2011) ("When state law prohibits outright the arbitration of a particular type of claim, the analysis is straightforward: The conflicting rule is displaced by the FAA.").

121. Id. ("But the inquiry becomes more complex when a doctrine normally thought to be generally applicable, such as duress or, as relevant here, unconscionability, is alleged to have been applied in a fashion that disfavors arbitration.").

122. Id. at 1748.

123. Id. at 1751 .

124. Id.

125. See supra Part I.A.1-2.
} 
fecting a party's right to arbitration. ${ }^{126}$

\section{A Critical Examination of Concepcion's Three-Part Test}

The facts underlying Concepcion are straightforward. ${ }^{127}$ Vincent and Liza Concepcion purchased cellular phone service from AT\&T Mobility, LLC (AT\&T). ${ }^{128}$ AT\&T promised a free phone with the deal. The Concepcions got their phones, but were charged about $\$ 30.00$ in sales tax. ${ }^{129}$ On this basis, the Concepcions argued that their phones were not free and filed a putative class action in federal district court raising false advertising and fraud claims. ${ }^{130}$ In response, AT\&T moved to compel arbitration under the terms of their service contract. The arbitration agreement contained therein barred class actions; ${ }^{131}$ however, the contract was also "pro-consumer" in various respects. For example, it guaranteed the Concepcions at least $\$ 7,500$ and twice their attorney's fees if they obtained an arbitration award greater than AT\&T's last settlement offer. ${ }^{132}$

California's Discover Bank rule provided that class action waivers rendered arbitration agreements unconscionable when (a) they were included in a consumer contract of adhesion; (b) the disputes involved only small amounts of damages; and (c) the drafter's conduct involved a scheme to cheat consumers. ${ }^{133}$ The district court denied AT\&T's motion to compel arbitration under Discover Bank, ${ }^{134}$ and the Ninth Circuit affirmed, holding that the FAA did not preempt the Discover Bank rule because it was simply "a refinement" of the generally applicable contract defense of unconscionability. ${ }^{135}$ The Supreme Court granted certiorari on the issue whether Section 2 of the FAA prohibited states "from condi-

\footnotetext{
126. See infra Part III.

127. The relative importance of certain facts to the Court's analysis of the case, however, is very much disputed in the courts and commentary alike.

128. Concepcion, 131 S. Ct. at 1744.

129. Id

130. Id.

131. The arbitration agreement provided for arbitration of all disputes between the parties, and included a class action waiver requiring that all claims be brought in the parties' "individual capacit[ies], and not as a plaintiff or class member in any purported class or representative proceeding." Id. at $1744-45$.

132. The agreement also provided, among other things, that in the event of arbitration, AT\&T "must pay all costs for non-frivolous claims," and that AT\&T was prevented from seeking reimbursement of its attorney's fees. Id. at 1744.

133. Id. at 1746 (citing Discover Bank v. Superior Court, 113 P.3d 1100, 1110 (Cal. 2005)).

134. Id. at 1745 .

135. Id.
} 
tioning the enforceability of certain arbitration agreements on the availability of classwide arbitration procedures." $" 136$

The Court first considered the type of analysis that was applicable to determine whether the FAA preempted the Discover Bank rule. The Court noted that it was not confronted with the "straightforward" analysis when a state law "prohibits outright the arbitration of a particular type of claim," in which case the state law "is displaced by the FAA."137 Rather, the Court addressed whether the FAA preempted the Discover Bank rule. This inquiry depended on whether "a doctrine normally thought to be generally applicable, such as duress or, as relevant here, unconscionability, is alleged to have been applied in a fashion that disfavors arbitration." 138 The Court reaffirmed the viability of generally applicable contract defenses in state law, unless a court relied on the uniqueness of an arbitration agreement as the basis for denying enforcement of the agreement. ${ }^{139}$ Section 2 of the FAA, the Court explained, preserves generally applicable contract defenses, but not state law rules that pose an obstacle to the objectives of the FAA. ${ }^{140}$

Here, it is worth pausing to discuss a major jurisprudential departure in Concepcion - the Court's pronouncement of the FAA's objectives. Importantly, the Court explained that the FAA's "overarching purpose" was "to ensure the enforcement of arbitration agreements according to their terms so as to facilitate streamlined proceedings." 141 This statement was a marked break from the past because the Court effectively suggested that the FAA's ultimate goal was not only to promote the "enforcement of arbitration agreements according to their terms," as the Court had written earlier in Volt. ${ }^{142}$ Concepcion is the first case in which the efficiency objectives of arbitration appear to trump the goal of enforcing agreements in the same manner as other contracts.

But the Court went further, and made a number of assumptions about

\footnotetext{
136. Id. at 1744 .

137. Id. at 1747 .

138. Id

139. Id. (noting that "a court may not 'rely on the uniqueness of an agreement to arbitrate as a basis for a state-law holding that enforcement would be unconscionable, for this would enable the court to effect what ... the state legislature cannot"' (citing Perry v. Thomas, 482 U.S. 483, 492 (1987)).

140. Id. at 1748 .

141. Id. (emphasis added).

142. Id. at 1748; see also Volt Info. Scis., Inc. v. Bd. of Trs. of Leland Stanford Junior Univ., 489 U.S. 468, 474 (1989).
} 
the "fundamental attributes of arbitration." 143 Arbitration, the Court reasoned, was intended to enable parties to design their own method of dispute resolution, which included establishing efficient proceedings tailored to a particular type of dispute, guaranteeing that the decision maker is a specialist in the relevant field, and ensuring that the proceedings are characterized by confidentiality, informality, increased speed, and lower costs. ${ }^{144}$ Thus, efficiency, speed, lower costs, and substantive expertise stood alongside the freedom to contract as arbitration's touchstones.

There is considerable tension in the majority's reasoning. As the Court acknowledged, arbitration is fundamentally a content-neutral procedure, and the parties to an arbitration agreement could agree to whatever procedure suits their purposes best. Yet, the Court also concluded that arbitration has the essential features of informality, speed, and costefficacy. Prodded by Justice Breyer's dissent, the majority recognized that these two policies could collide if parties opted for a slow, formal, or expensive process, by for example agreeing to class procedures or judicially-monitored discovery. ${ }^{145}$ However, the Court pronounced that these procedures would not really constitute arbitration: "[W] hat the parties in the aforementioned examples would have agreed to is not arbitration as envisioned by the FAA, lacks its benefits, and therefore may not be required by state law."146 Therefore, the Court's general notion of the "fundamental attributes of arbitration" was integral to the Court's holding, and as such, state regulations of arbitration could not compel a deviation from that ideal. ${ }^{147}$

Interestingly, the Court's general assumptions about arbitration appear to be suspect at best. Arbitration is not always preferred for its speed, cost, and informality. ${ }^{148}$ And it is hardly obvious that arbitration is usually cheaper, quicker, or more cost-effective than litigation. Arbitration, like litigation, is not a monolith, and can vary greatly depending on the nature of the dispute. Some forms of arbitration can take years or

\footnotetext{
143. Concepcion, 131 S. Ct. at 1748.

144. Id. at 1749; see also id. at 1751 (stating that "the switch from bilateral to class arbitration sacrifices the principal advantage of arbitration - its informality - and makes the process slower, more costly, and more likely to general procedural morass than final judgment").

145. See id. at 1753 ("States cannot require a procedure that is inconsistent with the FAA, even if it is desirable for unrelated reasons.").

146. Id. at 1753 .

147. Id. at 1748 .

148. For instance, some commentators have suggested that confidentiality also ranks among the reasons that institutions and companies choose to resolve their disputes. See generally Richard C. Reuben, Confidentiality in Arbitration: Beyond the Myth, 54 U. KAN. L. REv. 1255, 1255 (2006).
} 
even decades to reach a resolution. ${ }^{149}$ And although arbitration is often more informal than litigation, it is less predictable and the expenses of discovery for a large-scale arbitration are frequently comparable. ${ }^{150}$

Equally suspect was the Court's reliance on the AAA's institutional rules as evidence of the "fundamental attributes of arbitration," particularly regarding the length of arbitrations. ${ }^{151}$ There are a number of competing domestic and international institutional rules that parties may select off-the-shelf to govern a dispute. ${ }^{152}$ Moreover, contracting parties are free to craft ad hoc rules. By relying on the AAA's rules to the exclusion of any of the other sets of institutional rules, the Court arguably took an unnecessarily restrictive view of the nature of arbitration.

Moreover, the Court's assumptions about arbitration are rooted in a historicist line of reasoning, one which casts aside any development in the meaning of arbitration in the course of the past 80 years. ${ }^{153}$ In other words, the Court looked to the drafting history of the FAA in the 1920s to determine what arbitration means today. As the Court noted in Concepcion: "We find it unlikely that in passing the FAA Congress meant to leave the disposition of these procedural requirements to an arbitrator." 154 Undoubtedly, class arbitration "was not even envisioned by Congress

149. See, e.g., Charles D. Coleman, Is Mandatory Employment Arbitration Living Up to Its Expectations? A View from the Employer's Perspective, 25 ABA J. LAB. \& EMP. L. 227, 236-37 (2010) (noting that arbitrations involving pro se claimants are likely to result in higher costs and take longer while recent decisions, like Bell Atlantic Corp. v. Twombly, 550 U.S. 554 (2007), and Ashcroft v. Iqbal, 556 U.S. 662 (2009), have afforded time and cost advantages to litigation).

150. See, e.g., Lawrence W. Newman, Agreements to Arbitrate and the Predictability of Procedures, 113 PENN ST. L. REV. 1323 (2009) ("Businesses that frequently use arbitration have been increasingly critical of the fact that it has become more similar to litigation-particularly US-style litigation in United States courts - in large part because of increased procedural activity, including discovery. As arbitration becomes more formal and more complex, it becomes more expensive.").

151. Concepcion, 131 S. Ct. at 1751 (citing Brief of American Arbitration Ass'n as Amicus Curiae in Support of Neither Party at 22-25, Stolt-Nielsen S.A. v. Animalfeeds Int'l Corp., 559 U.S. 662 (2010) (No. 08-1198), 2009 WL 2896309, at *22-25.

152. A recent study found that a sample of employment contracts that included arbitration clauses designating 17 different types of arbitration rules. Erin O'Hara O'Connor et al., Customizing Employment Arbitration, 98 IowA L. REV. 133, 163-64 (2012). While about 70 percent of these arbitration agreements specified the AAA, six different types of AAA rules were selected. Id. at 164 . For other types of disputes, different sets of arbitration rules and procedures may be utilized. For domestic commercial disputes, parties can choose from the Commercial Arbitration Rules of the AAA, available at http://www.adr.org/commercial, the JAMS Comprehensive Arbitration Rules and Procedure, available at http://www.jamsadr.com/rules-comprehensive-arbitration/, or the National Arbitration Forum Code of Procedure, available at http://www.adrforum.com/, among others.

153. See Concepcion, $131 \mathrm{~S}$. Ct. at 1751; see also Marks, supra note 68, at 42 (noting that the Court looked to the intent of the FAA's drafters to support the proposition that that FAA only encourages bilateral arbitration).

154. Concepcion, 131 S. Ct. at 1751. 
when it passed the FAA in $1925,{ }^{, 155}$ which was an era in which even commercial arbitration was in its infancy. ${ }^{156}$ However, arbitrationoriginally intended to be a flexible way to resolve disputes - is a rapidly evolving procedure, and run-of-the-mill consumer or employment arbitration today bears little resemblance to the procedures that may have been envisioned by the FAA's drafters (to the extent they contemplated a paradigmatic arbitration procedure). Indeed, the Court recognized this when it agreed with the California Supreme Court that "class arbitration is a "relatively recent development.",157

After describing the objectives of arbitration, the Court held that the Discover Bank rule impermissibly interfered with them. ${ }^{158}$ The practical effect of the Discover Bank rule, according to the Court, was to allow any party to a consumer contract to demand class-wide arbitration ex post. ${ }^{159}$ Relying on its recent Stolt-Nielsen decision, ${ }^{160}$ the Court concluded that class-wide arbitration was fundamentally different from bilateral arbitration-class actions require procedural formality and a slower, costlier process. ${ }^{161}$ Accordingly, the Court in Concepcion held that the Discover Bank rule "stands as an obstacle" to the purposes and objectives of Congress as set forth in the FAA, and was therefore preempted. $^{162}$

Justice Breyer, writing for the four dissenting Justices in Concepcion, disagreed that the Discover Bank rule posed an obstacle to the ac-

155. Id

156. See Andrew P. Lamis, The New Age of Artificial Legal Reasoning as Reflected in the Judicial Treatment of the Magnuson-Moss Act and the Federal Arbitration Act, 15 LOY. CONSUMER L. REV. 173, 195 n.77 (2003) (discussing early methods of commercial arbitration).

157. Concepcion, $131 \mathrm{~S}$. Ct. at 1751 (internal citation omitted).

158. Id. at 1750 .

159. Id.

160. See Stolt-Nielsen S.A. v. AnimalFeeds Int'l Corp., 559 U.S. 662, 686-87 \& n.10 (2010) (holding, among other things, that an arbitrator exceeded his powers by compelling class arbitration when the parties had not agreed to this procedure in their arbitration agreement).

161. Concepcion, 131 S. Ct. at 1750-51 (citing Stolt-Nielsen, 559 U.S. at 686).

162. Id. at 1753 (citing Hines v. Davidowitz, 312 U.S. 52, 67 (1941)). Justice Thomas provided the crucial fifth vote with his concurrence in Concepcion, creating a majority alongside Justice Scalia's opinion. Justice Thomas continued to "adhere to [his] views on purposes-and-objectives preemption," meaning that he thought that form of preemption analysis was inherently flawed. See id. at 1754 (Thomas, J., concurring). Rather, in his view, $\S 2$ of the FAA was limited elsewhere by the text of the FAA to account for the principle that "courts cannot refuse to enforce arbitration agreements because of a state public policy against arbitration, even if the policy nominally applies to 'any contract."' Id. However, because Justice Thomas considered that his textual reading of the FAA generally would reach the same conclusion as that of Justice Scalia, he "reluctantly" joined the Court's opinion. Id. 
complishment and execution of the FAA. ${ }^{163}$ First, the dissent noted that the Discover Bank rule did not categorically void every arbitration agreement that included a class action waiver. ${ }^{164}$ Rather, in the dissent's view, the Discover Bank rule only voided "some" class action waivers in the arbitration context as unconscionable, which therefore was just a specific application of the more general doctrine of unconscionability. ${ }^{165}$

The dissent next took issue with the notion, apparently adopted by the majority, that the FAA's primary objective was to ensure efficiency and the other procedural advantages that often may accompany arbitration. ${ }^{166}$ According to the dissent, the "primary" and "basic" objective of the FAA was to "secure the "enforcement' of agreements to arbitrate,",167 and to "assur[e] that courts treat arbitration agreements 'like all other contracts," respectively. ${ }^{168}$ The dissent found lacking any support in the text of the FAA and its legislative history for the proposition that individual - rather than class - arbitration is a "fundamental attribut[e]" of arbitration, ${ }^{169}$ or that the Discover Bank rule would serve to discourage the use of arbitration. ${ }^{170}$

Accordingly, the dissent wrote that the relative advantages and disadvantages of class proceedings addressed at length by the majority were not implicated because the Discover Bank rule placed arbitration contracts on equal footing as other contracts. ${ }^{171}$ Because the Discover Bank rule applies equally to litigation and arbitration and thus did not single out arbitration for disfavored treatment, the dissent wrote that it was un-

163. Id. at 1756-57 (Breyer, J., dissenting).

164. Id. at 1757 (Breyer, J., dissenting).

165. See id. at 1757 (Breyer, J., dissenting) (explaining "[t]he Discover Bank rule does not create a 'blanket policy in California against class action waivers' . . . Instead, it represents the 'application of a more general [unconscionability] principle"') (internal citation omitted)).

166. Id. at 1758 (Breyer, J., dissenting) (observing that Congress's primary goal with the FAA was actually to ensure the enforcement of arbitration agreements); see also id. at 1748 (majority opinion) (writing that "[t]he overarching purpose of the FAA ... is to ensure the enforcement of arbitration agreements according to their terms so as to facilitate streamlined proceedings"); $i d$. at 1749 (stating that "[t]he point of affording parties discretion in designing arbitration processes is to allow for efficient, streamlined procedures tailored to the type of dispute"); id. at 1751 (holding that "informality" is the "principal advantage of arbitration").

167. Id. at 1758 (Breyer, J., dissenting) (citing Dean Witter Reynolds Inc. v. Byrd, 470 U.S. 213, $221(1985))$.

168. Id. at 1761 (Breyer, J., dissenting) (quoting Buckeye Check Cashing, Inc. v. Cardegna, 546 U.S. 440, 447 (2006)).

169. Id. at 1759 (Breyer, J., dissenting) ("Where does the majority get its contrary idea-that individual, rather than class, arbitration is a 'fundamental attribut[e]' of arbitration.... [I]t is unlikely to be able to trace its present view to the history of the arbitration statute itself.").

170. Id. at 1760 (Breyer, J., dissenting).

171. Id. at 1762 (Breyer, J., dissenting). 
precedented for the Court to strike down the California law as inconsistent with the FAA. ${ }^{172}$ Rather, the dissent stated, general contract defenses such as duress and unconscionability were defenses to enforcement of an arbitration agreement under the FAA, and "arbitration law normally leaves such matters to the States." "I73 the absence of "meaningful precedent" supporting the majority's decision, the dissent would have upheld the Discover Bank rule to "honor federalist principles." 174

\section{American Express}

In its recent American Express decision, the Supreme Court applied the principles of Concepcion to compel arbitration of federal antitrust claims, even though the plaintiffs had alleged that a class action waiver and other contract terms foreclosed any meaningful ability to vindicate their rights in arbitration. Below we give an overview of the American Express case before we turn to discuss competing perspectives of the analytical rule established by Concepcion.

At issue in American Express was a standard-form contract between American Express and certain merchants that accepted American Express charge cards. ${ }^{175}$ The contract contained a mandatory arbitration clause that prohibited all class action claims. ${ }^{176}$ The merchants filed suit under the Sherman Act, alleging that American Express used its market power to force merchants to accept payment by charge cards and to impose fees that are about 30 percent higher than the fees of competing credit cards. ${ }^{177}$ The merchants presented undisputed testimony from an economist that "it would not be worthwhile for an individual plaintiff . . . to pursue individual arbitration or litigation where the out-of-pocket costs, just for the expert economic study and services, would be at least several hundred thousand dollars, and might exceed \$1 million."178

The Second Circuit struck down the arbitration clause because it created a scenario where it would be "financially impossible for the plaintiffs to seek to vindicate their federal statutory rights" if a judicial class

\footnotetext{
172. Id. at 1758-59, 1761 (Breyer, J., dissenting).

173. Id. at 1760 (Breyer, J., dissenting).

174. Id. at 1762 (Breyer, J., dissenting).

175. Am. Express Co. v. Italian Colors Rest., 133 S. Ct. 2304 (2013).

176. Id. at 2308 .

177. Id.

178. In re Am. Express Merchs. Litig., 667 F.3d 204, 218 (2d Cir. 2012), rev'd sub nom. Am. Express Co. v. Italian Colors Rest., 133 S. Ct. 2304 (2013).
} 
action was unavailable. ${ }^{179}$ In so ruling, the Second Circuit distinguished Concepcion and Stolt-Nielsen, taking pains to emphasize that it was not holding "that class action waivers in arbitration agreements are per se unenforceable, or even that they are per se unenforceable in the context of antitrust actions." ${ }^{180}$ Rather, the Second Circuit explained that the class action waiver was "considered on its own merits, [and] based on its own record." $" 181$

The Supreme Court reversed the Second Circuit by a vote of 5-3. ${ }^{182}$ Writing for the majority, Justice Scalia rejected the merchants' argument that the arbitration agreements were unenforceable under Mitsubishi and Randolph, despite the merchants' claim that they were prevented from effectively vindicating their rights under federal antitrust laws. The majority characterized the "effective vindication" principle as a "judgemade exception to the FAA" that "originated as dictum." 183 Rather than flatly rejecting this principle of federal common law, the majority held that the plaintiffs had not shown that the American Express arbitration agreement operated as a prospective waiver of their right to pursue federal antitrust claims. ${ }^{184}$

According to the majority, the class action waiver and related contract terms merely limited who could arbitrate a claim, which did not rise to the level of a waiver of the merchants' right to pursue their federal statutory remedies. ${ }^{185}$ As the Court explained, "the fact that it is not worth the expense involved in proving a statutory remedy does not constitute the elimination of the right to pursue that remedy."186

The American Express majority unreservedly applied Concepcion's preemption-based reasoning to facts that presented a potential conflict between federal antitrust law and the FAA. The majority not only dismissed the notion that Concepcion was "a case involving pre-emption and not the effective-vindication exception," but even went so far as to write that Concepcion "all but resolves this case." jority explained that Concepcion had "invalidated a law" requiring class

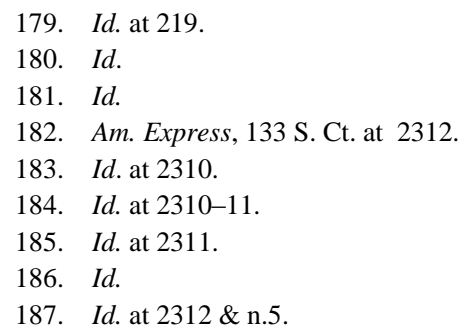


arbitration - notably omitting the fact that it was a state law-"because that law "interfere[d] with fundamental attributes of arbitration," namely, informality, efficiency, reduced costs, and speed. ${ }^{188}$

Significantly, the American Express majority stated that the Court in Concepcion had "specifically rejected the argument that class arbitration was necessary to prosecute claims "that might otherwise slip through the legal system." "189 And, extrapolating from this principle, the majority held that "the FAA's command to enforce arbitration agreements trumps any interest in ensuring the prosecution of low-value claims," which is an interest " unrelated' to the FAA." 190 The majority wrote that the effective vindication of rights analysis as employed by the Second Circuit required litigation about the merits claim-by-claim, the cost of the undertaking, as well as the potential recovery; and the evidence was required to prevail on the merits. ${ }^{191}$ According to the majority, such a "preliminary litigating hurdle" would sacrifice the "speedy resolution that arbitration ... was meant to secure," as the class arbitration requirement had done in Concepcion, and was therefore not permitted under the FAA. ${ }^{192}$

Justice Kagan wrote a vehement dissent in which Justices Ginsburg and Breyer joined. In a "nutshell," the dissent wrote, the American Express arbitration clause "imposes a variety of procedural bars that would make pursuit of the antitrust claim a fool's errand," meaning that if it were enforced, American Express effectively "insulated itself from antitrust liability." "193 The dissent determined that the effective vindication doctrine barred enforcement of an arbitration agreement when doing so would "confer immunity from potentially meritorious federal claims." 194 The dissent stated that an arbitration agreement "may not thwart federal law, irrespective of exactly how it does so," and highlighted the overriding importance of the effective vindication principle, which "reconciles the [FAA] with all the rest of federal law." "195

The dissent explained that there were "endless" opportunities for an arbitration agreement to effectively insulate a company from liability,

\footnotetext{
188. See id. at 2312 (alteration in original) (quoting AT\&T Mobility LLC v. Concepcion, $131 \mathrm{~S}$. Ct. 1740,1748 (2011)).

189. Id. (quoting Concepcion, 131 S. Ct. at 1753).

190. Id. at 2312 n.5.

191. Id. at 2312 .

192. Id.

193. Id. at 2313 (Kagan, J., dissenting).

194. Id.

195. Id
} 
besides a plainly unenforceable exculpatory provision, such as: "Merchants may bring no Sherman Act claims." each of the following would have an "identical effect": (1) "outlandish" filing fees; (2) absurd statutes of limitations, e.g., one day; (3) an agreement preventing introduction of certain kinds of evidence necessary to prove certain claims, e.g., economic testimony for an antitrust claim; (4) the appointment of an obviously biased arbitrator, e.g., the American Express CEO (or his designee); or (5) limitations on the arbitrator's authority to grant meaningful relief. ${ }^{197}$ That the effective vindication principle bars enforcement of such terms in an arbitration clause, the dissent wrote, was well supported by precedent. Moreover, the dissent found that application of this principle furthered the FAA's purposes (as well as other federal statutes) by "ensuring that arbitration remains a real, not faux, method of dispute resolution.",198

The dissent would have judged the American Express arbitration agreement in view of its related contract provisions, such as the confidentiality clause, the bar on joinder or consolidation of parties, and the prohibition on cost shifting to American Express, even if the merchants were ultimately successful on their claims. ${ }^{199}$ Because an appropriate expert report would indisputably cost at least several hundred thousand dollars, and an individual plaintiff would shoulder all such costs, the dissent concluded that the American Express contract read in its entirety rendered arbitration "prohibitively expensive," thus preventing effective vindication of the merchants' rights. ${ }^{200}$

\section{Alternative Interpretations of Concepcion}

We read Concepcion as establishing a three-prong disjunctive test: the FAA preempts a state law rule if that rule (1) prohibits outright the arbitration of a particular type of claim; (2) violates the FAA's antidiscrimination principle by singling arbitration for disparate treatment; or (3) interferes with arbitration's fundamental attributes of efficiency, reduced costs, speed, and informality. ${ }^{201}$ Some courts and commentators

\footnotetext{
196. Id. at 2313-14.

197. Id. at 2314.

198. Id. at 2315.

199. See id. at 2316 (stating that when the agreement was viewed as a whole, it served as a prospective waiver of liability for Sherman Act claims).

200. Id. at 2316-17 (citations omitted).

201. See infra Part III (discussing Concepcion's impact vis-à-vis federal rules and regulations).
} 
have interpreted Concepcion differently and we believe that these interpretations often fail to appreciate the full import of Concepcion. Such constrained interpretations of Concepcion are even less persuasive following American Express. We address these alternative interpretations, which are by no measure mutually exclusive or completely inconsistent with our reading of this landmark decision.

\section{a. Concepcion as Limited to Federal Courts}

One of the narrowest interpretations of Concepcion is that its reasoning is limited to actions brought in federal court. ${ }^{202}$ It is based on the fact that Justice Thomas's concurrence was necessary to create a majority, and it relies on the position taken by Justice Thomas in Allied-Bruce Terminix and other cases that the FAA simply "does not apply in state courts." 203 Adherents of this argument would say that Justice Scalia or Justice Thomas had no occasion to mention this severe limitation on Concepcion because the dispute arose in federal court, and thus Justice Thomas would have agreed that the FAA's procedural rules applied in any event. $^{204}$

The position that the FAA does not apply in state courts has never attracted more than a minority of the Supreme Court. Significantly, this possible interpretation is undermined because Justice Thomas concurred in full in Justice Scalia's opinion, and did not indicate that he would have reached a different result if Concepcion arose in state court. ${ }^{205}$ As far as we are aware, no court has adopted this position. ${ }^{206}$ In any event, this in-

202. Several commentators have speculated whether Concepcion could be so limited. See, e.g., Michael A. Wolff, Is There Life After Concepcion? State Courts, State Law, and the Mandate of Arbitration, 56 ST. LouIS U. L.J. 1269, 1276-78 (2012) (noting the possibility that Justice Thomas's fifth vote for the majority was intended to limit the majority's holding to cases arising in federal court); Sarah Rudolph Cole, On Babies and Bathwater: The Arbitration Fairness Act and the Supreme Court's Recent Arbitration Jurisprudence, 48 Hous. L. REv. 457, 489 n.148 (2011) (noting the importance of the fact that Concepcion originated in federal court).

203. Allied-Bruce Terminix Companies, Inc. v. Dobson, 513 U.S. 265, 285-86 (1995) (Thomas, J., dissenting); see also id. at 291 (arguing that "the FAA treats arbitration simply as one means of resolving disputes that lie within the jurisdiction of the federal courts")

204. See id. at 291 ("[T]he reason that $\S 2$ does not give rise to federal-question jurisdiction is that it was enacted as a purely procedural provision. For the same reason, it applies only in the federal courts." (emphasis omitted)). Similarly, there would have been no occasion for the Justices to mention this potential distinction in American Express, which also came up through the federal courts.

205. See generally AT\&T Mobility LLC v. Concepcion, 131 S. Ct. 1740, 1753-56 (2011) (Thomas, J., dissenting).

206. See, e.g., McKenzie Check Advance of Fla., LLC v. Betts, 112 So. 3d 1176, 1184-85 (Fla. 2013) (rejecting the argument that "Concepcion does not apply to actions brought in state court" 
terpretation fails to account for the fact that in his concurrence, Justice Thomas expressed the importance of "giv[ing] lower courts guidance from a majority of the Court," thus implicitly endorsing the broad reasoning of the opinion regarding the fundamental attributes of arbitration. ${ }^{207}$

\section{b. Concepcion as Hinging on the Pro-Consumer Aspects of the Arbitration Agreement}

Another restrictive interpretation of Concepcion limits the decision in large part to its facts. Under this interpretation, the outcome was uniquely the product of an arbitration agreement containing so many proconsumer terms that the Court had characterized it as "essentially guarantee[ing]" consumers the ability to press meritorious claims that would make them whole. ${ }^{208}$ The penultimate paragraph of Concepcion provides some evidence for this interpretation:

The dissent claims that class proceedings are necessary to prosecute smalldollar claims that might otherwise slip through the legal system. But States cannot require a procedure that is inconsistent with the FAA, even if it is desirable for unrelated reasons. Moreover, the claim here was most unlikely to go unresolved. As noted earlier, the arbitration agreement provides that AT \& T will pay claimants a minimum of $\$ 7,500$ and twice their attorney's fees if they obtain an arbitration award greater than AT \& T's last settlement offer. The District Court found this scheme sufficient to provide incentive for the individual prosecution of meritorious claims that are not immediately settled, and the Ninth Circuit admitted that aggrieved customers who filed claims would be "essentially guarantee[d]" to be made whole. Indeed, the District Court concluded that the Concepcions were better off under their arbitration agreement with AT \& T than they would have been as participants in a class action, which "could take months, if not years, and which may merely yield an opportunity to

based on Justice Thomas's longstanding position on the FAA, because "Concepcion does not make the distinction ... nor does Justice Thomas in his concurrence"); Feeney v. Dell Inc., No. MICV 2003-01158, 2011 WL 5127806, at *7 n.10 (Mass. Super. Ct. Oct. 4, 2011) (rejecting argument that Concepcion does not apply "because this case arose in the state courts and Justice Thomas, who joined the Concepcion majority, votes against application of the FAA to state court proceedings"), rev'd on different grounds, 993 N.E.2d 329 (Mass. 2013); see also Schnuerle v. Insight Commc'ns Co., L.P., 376 S.W.3d 561, 570 (Ky. 2012) (rejecting argument that Justice Thomas's separate opinion was not a "full concurrence").

207. Concepcion, 131 S. Ct. at 1754 (Thomas, J., concurring). And, in any event, Justice Thomas concluded that the Discover Bank rule did not operate to bar arbitration of the parties' dispute based on a "textual interpretation" of the FAA, and notably, he stated that this test "will often lead to the same outcome" as Justice Scalia's obstacle preemption analysis. Id. at 1753-54.

208. Id. at 1753 (majority opinion). 
submit a claim for recovery of a small percentage of a few dollars.,209

Under this interpretation, the Court found that the generally "proconsumer" nature of the Concepcion arbitration agreement was material to its resolution of the case. The Court rejected the proposition that class proceedings were necessary to prosecute small-dollar claims, and arguably did so because the "scheme [was] sufficient to provide incentive for the individual prosecution of meritorious claims that were not immediately settled," and because aggrieved customers were "essentially guarantee[d]" to be made whole. ${ }^{210}$ Therefore, by limiting the holding to the narrow, fact-bound interpretation of Concepcion, if the arbitration agreement's terms were less consumer-friendly, Concepcion would not require arbitration when an otherwise-applicable, facially neutral state law would have foreclosed arbitration.

Some commentators have noted the possibility that "[c]ourts could limit Concepcion to its unusual facts - emphasizing that the arbitration clause used by [AT\&T] was extremely pro-consumer, ${ }^{, 211}$ and indeed, a few courts have attempted to limit Concepcion in this manner. ${ }^{212}$ In Feeney v. Dell, Inc., the Supreme Judicial Court of Massachusetts offered perhaps the most vigorous articulation of this position. ${ }^{213}$ There, the court concluded that Concepcion does not indorse the enforcement of an arbitration clause that includes a class action waiver when "a plaintiff can demonstrate that he or she effectively cannot pursue a claim against

209. Id. at 1753 (quoting Laster v. AT \& T Mobility LLC, 584 F.3d 849, 856 n.9 (9th Cir. 2009); Laster v. T-Mobile USA, Inc., No. 05cv1167 DMS (AJB), 2008 WL 5216255, at *12 (S.D. Cal. Aug. 11, 2008)).

210. Concepcion, 131 S. Ct. at 1753.

211. See, e.g., Sternlight, supra note 27 , at 708 (noting the argument, but finding that most courts have not so limited their reading of Concepcion and instead are broadly applying the decision "as a 'get out of class actions free' card").

212. See, e.g., Feeney v. Dell Inc., 989 N.E.2d 439, 461 (Mass. 2013) (separating the Concepcion fact scenario from other arbitration agreements by noting that where an "arbitration agreement does not feature the safeguards found in the Concepcion agreement, a court may still invalidate a class waiver"); Brewer v. Mo. Title Loans, 364 S.W.3d 486, 493-94 (Mo. 2012) (en banc) (distinguishing Brewer from Concepcion on the basis that expert testimony in Brewer supported a finding that there was "no practical, viable means of individualized dispute resolution").

213. The Supreme Judicial Court of Massachusetts's decision in Feeney was issued eight days before the Supreme Court's decision in American Express was released. The Massachusetts court subsequently reversed course on reconsideration, writing, among other things, that the Supreme Court in American Express "made clear that its discussion in Concepcion of the likelihood that those plaintiffs' claims could be resolved in individual arbitration did not contribute to its holding in that case and, in doing so, thwarted our reliance ... on that discussion." Feeney v. Dell Inc., 993 N.E.2d 329, 331 (Mass. 2013). 
the defendant in individual arbitration." 214 The Massachusetts court supported this position, writing that "Concepcion goes to great length to demonstrate the overall fairness of that agreement and the Court's belief that a consumer could successfully pursue a remedy under the regime it established."215 Likewise, the Supreme Court of Missouri in Brewer v. Missouri Title Loans distinguished the arbitration agreement at issue from the agreement in Concepcion. ${ }^{216}$ In that case, the court characterized the agreement at issue as "extremely one-sided" and a "substantial obstacle ... to the resolution of any consumer disputes against the title company," as contrasted with the arbitration agreement in Concepcion, about which the Missouri court approvingly noted that "AT\&T shouldered the costs of arbitration." 217

A fact-bound interpretation of Concepcion emphasizing the proconsumer nature of the dispute resolution process is not persuasive. The Court's language in Concepcion about the pro-consumer nature of the arbitration agreement admittedly appears to have been included in response to the dissent's suggestion that "class proceedings are necessary to prosecute small-dollar claims that might otherwise slip through the legal system." 218 However, in the very next sentence, the Court deemed these concerns legally irrelevant, stating that the FAA preempted conflicting state laws, and that "[s]tates cannot require a procedure that is inconsistent with the FAA, even if it is desirable for unrelated reasons." ${ }^{219}$ Considering the context and structure of the opinion, this language merely suggests that the Court believed the dissent's concerns that consumers would not have a remedy against AT\&T were not factually supported in this case, but, in any event, legally irrelevant. Moreover, it is difficult to tell how the Court's preemption analysis would have fared better under a more one-sided contract. Therefore, even before American Express, most courts disagreed with a fact-based interpretation of Concepcion resting on the pro-consumer elements of the arbitration agreement, concluding instead that these facts were not material to the Court's reasoning. ${ }^{220}$

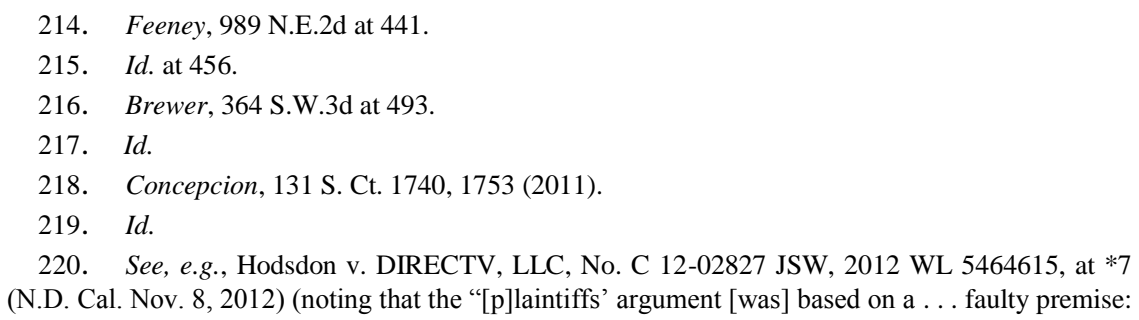


If the pro-consumer aspects of the arbitration agreement or the fact that the aggrieved customers were "essentially guaranteed to be made whole" 221 in bilateral arbitration were material to the Court's analysis in Concepcion, one likely would have expected a different result in American Express. By contrast, in American Express, even though the cost of individual arbitration exceeded any potential recovery, the majority rejected the merchants' effective vindication argument largely on the basis that Concepcion "established ... that the FAA's command to enforce arbitration agreements trumps any interest in ensuring the prosecution of low-value claims."222 In other words, in American Express, a merchant bringing a federal antitrust claim was essentially guaranteed not to be made whole because the costs of bilateral arbitration exceeded the potential recovery. Thus, Concepcion cannot be understood to hinge on the pro-consumer aspects of the arbitration agreement in that case, either based solely on a reading of Concepcion or interpreted in light of American Express.

c. Concepcion as Hinging on the Discriminatory Nature or Application of the Discover Bank Rule

Another restrictive reading of Concepcion emphasizes that the decision was merely an extension of the anti-discrimination principle, i.e., that arbitration agreements may not be singled out for disfavored treatment. Under this view, there are several reasons why the Discover Bank rule might have been discriminatory.

First, the Discover Bank rule was arguably discriminatory in its judicial application. One might try to characterize the rule as one that almost

that the Concepcion ruling was dependent on the consumer-friendly aspects of the provision at issue in that case" and that "courts have generally rejected [that] very claim"); McKenzie Check Advance of Fla., LLC, 112 So.3d 1176, 1187-88 (Fla. 2013) (stating that Concepcion precludes class action waivers from being invalidated simply because small-value claims would prevent consumers from obtaining counsel); Schnuerle v. Insight Commc'ns Co., L.P., 376 S.W.3d 561, $572-73$ (Ky. 2012) (stating that "[a] careful reading of Concepcion discloses that the unusually consumer-friendly terms of the AT \& T agreement were not particularly relevant to the Supreme Court's holding," and that "[t]hat factor simply was not central to the Supreme Court's holding"); NAACP of Camden Cnty. E. v. Foulke Mgmt. Corp., 24 A.3d 777, 799 (N.J. Super. Ct. App. Div. 2011) (finding that the attempts to distinguish Concepcion, including the argument that Concepcion's arbitration provisions in dispute were less consumer-friendly, unpersuasive).

221. Concepcion, $131 \mathrm{~S}$. Ct. at 1753 (internal grammatical marks omitted).

222. Am. Express Co. v. Italian Colors Rest., 133 S. Ct. 2304, 2312 n.5 (2013). By contrast, the dissent argued that the effective-vindication rule was not at issue in - and thus not implicated by-Concepcion, given the fact that the arbitration agreement in that case had a "host of features ensuring that 'aggrieved customers who filed claims would be essentially guaranteed to be made whole." Id. at 2320 (Kagan, J., dissenting) (quoting Concepcion, 131 S. Ct. at 1753). 
categorically invalidated certain arbitration agreements. According to this interpretation, the Court in Concepcion would have reached a different conclusion if the challenged state law had less of a disparate impact on the enforcement of arbitration agreements. In other words, so long as state law restrictions on arbitration determine the enforceability of the agreement based on the specific facts of the case, those restrictions can be distinguished from Concepcion.

This interpretation arguably follows from the Supreme Court's description of the Discover Bank rule as one that "condition[ed] the enforceability of certain arbitration agreements on the availability of classwide arbitration procedures." ${ }^{223}$ Moreover, the Court stated that the rule "classif[ies] most collective-arbitration waivers in consumer contracts as unconscionable." 224 And, significantly, the Court found noteworthy, although "not definitive," certain statistical evidence that "California's courts have been more likely to hold contracts to arbitrate unconscionable than other contracts." 225

After Concepcion, there is some support for the proposition that the nearly categorical application of the Discover Bank rule was a material consideration in the Court's analysis. ${ }^{226}$ A few courts have seized on the Court's description of Discover Bank to argue that the FAA did not preempt other challenged state laws that do not categorically discriminate against arbitration, but rather examined the specific facts underlying any given dispute.

The Supreme Court of Missouri in Brewer v. Missouri Title Loans, for example, emphasized that the "practical effect" of the Discover Bank rule had been to "create[] an essentially categorical requirement of class arbitration.",227 Thus, the court determined, the Discover Bank rule rendered class arbitration waivers unconscionable "even if traditional factors of unconscionability are absent,"228 and even where, as in Concepcion, bilateral arbitration could be more advantageous to consumers than pro-

\footnotetext{
223. Concepcion, 131 S. Ct. at 1744 (emphasis added).

224. Id. at 1746 (emphasis added).

225. Id. at 1747 .

226. See, e.g., Marks, supra note 68, at, 43-44 (stating that if Concepcion was merely an extension of the well-settled principle that state laws "may not single out arbitration provisions for different treatment," "an unconscionability ruling forbidding class-action waivers on an ad hoc basis could survive Concepcion"); Rhonda Wasserman, Legal Process in a Box, or What Class Action Waivers Teach Us About Law-Making, 44 LOY. U. CHI. L.J. 391, 439 (2012) (stating that some lower courts have "read[] Concepcion [sic] narrowly to preclude only categorical rules that ban class action waivers").

227. Brewer v. Missouri Title Loans, 364 S.W.3d 486, 489 (Mo. 2012) (en banc).

228. Id.
} 
ceeding as part of a class. ${ }^{229}$ The logic underlying this narrow interpretation of Concepcion is in its most basic form the following: while Concepcion held that a rule that categorically invalidates arbitration clauses is preempted by the FAA, our analysis is appropriately grounded on the facts of the case. There is no mystery to the appeal of this narrow interpretation. Some courts are reluctant to find that all restrictions on class arbitration waivers are automatically preempted by the FAA after Concepcion. $^{230}$

Conversely, most courts have taken the opposite approach and held that Concepcion categorically strikes down all state law restrictions on class arbitration waivers as preempted by the FAA. As one leading commentator on the FAA put it, "[a]s interpreted by most courts, [Concepcion] is destroying virtually all possible attacks on arbitral class action waivers." 231 Therefore, while plaintiffs repeatedly have argued after Concepcion that class action waivers can be determined to be unconscionable on a case-by-case basis, generally this argument has not been considered persuasive. ${ }^{232}$

The majority of courts have the better argument. As noted above, the Court's reasoning was not grounded in an anti-discrimination principle, but rather in a conflict between the purposes of the FAA and the effects of the Discover Bank rule. If that rule was invalid merely because it was applied in a discriminatory manner, the Court might have said so and left the opinion at that. But the Court made that point ${ }^{233}$ and went much further. ${ }^{234}$ And any interpretation of Concepcion that renders most of the opinion superfluous dicta-i.e., the Discover Bank rule conflicts with the fundamental attributes of arbitration and purposes of the FAAcannot be correct.

229. See id. at 494 ("Instead, the critical flaw leading to the preemption of the Discover Bank rule was that it required class arbitration even if class arbitration disadvantaged consumers and was unnecessary for the consumer to obtain a remedy.").

230. See, e.g., Anderson v. Maronda Homes, Inc. of Fla., 98 So.3d 127, 131 (Fla. Dist. Ct. App. 2012) (LaRose, J., specially concurring) (opining that "it is not entirely clear" whether Concepcion "establishes a categorical rule against class arbitration").

231. Sternlight, supra note 27 , at 709 .

232. See, e.g., Clemins v. GE Money Bank, No. 11-CV-00210, 2012 WL 5868659, at *5 (E.D. Wis. Nov. 20,2012) (rejecting plaintiffs' argument "that Concepcion only prohibits states from making class-action waivers invalid per se and that a court can still find a class action waiver to be unconscionable on a case-by-case basis").

233. See AT\&T Mobility LLC v. Concepcion, 131 S. Ct. 1740, 1747 (2011) (stating that a generally applicable contract defense cannot "rely on the uniqueness of an agreement to arbitrate as a basis for a state-law holding that enforcement would be unconscionable" (quoting Perry v. Thomas, 482 U.S. 483,493 n.9 (1987))).

234. See id. at 1748-53 (discussing the Discover Bank rule's interference with the "fundamental attributes of arbitration," thereby "creat[ing] a scheme inconsistent with the FAA"). 
Moreover, American Express does not support the argument that Concepcion's reasoning was based on the fact that the California law had been applied by the courts in a manner that discriminated against arbitration. The Second Circuit's analysis in that case indisputably was grounded in the facts of the parties before the court: it was undisputed that the plaintiff's cost of individual arbitration would exceed any potential recovery. ${ }^{235}$ Moreover, nowhere in the American Express majority's analysis did the Court suggest that the federal courts had been applying the "effective vindication" principle in Mitsubishi and Randolph in a manner that discriminated against arbitration agreements. Indeed, in her dissent, Justice Kagan plainly stated that the opposite was true: "[F]or almost three decades, courts have followed our edict that arbitration clauses must usually prevail, declining to enforce them in only rare cases. 236

The second variation of the anti-discrimination theory characterizes the Discover Bank rule as discriminatory by its very nature, irrespective whether the rule had any practical effect on the arbitration process. Under this view, the Discover Bank rule was discriminatory because it assumed arbitration would be an inadequate substitute to litigation without a class action mechanism. ${ }^{237}$ This interpretation derives support from the Court's dicta about the impropriety of imposing judicial procedure, such as the Federal Rules of Evidence, in the arbitration process. ${ }^{238}$ Of course this dicta is open to multiple interpretations, as "Justice Scalia does not elaborate on why the 'horribles' . . would be preempted."239

Properly read, Concepcion is not grounded in this variation of the anti-discrimination principle. First, the Court in Concepcion plainly mentioned judicially monitored discovery and strict evidentiary standards in the same breath during its discussion that the FAA was intended to provide parties the opportunity to design "streamlined proceedings." 240 And

\footnotetext{
235. See Am. Express Co. v. Italian Colors Rest., 133 S. Ct. 2304, 2308 (2013) (stating that arbitration costs could total more than a million dollars while the maximum recovery a plaintiff could hope to receive was $\$ 12,850)$.

236. Id. at 2315-16 (Kagan, J., dissenting) (citing Brief of the United States as Amicus Curiae, at 26-27).

237. See Horton, Federal Arbitration Act Preemption, supra note 27 at 1237-38 (noting that plaintiffs would lack incentive to bring claims with small damages if there was no class action op-

238. See id. at 1272 (stating that "[a]fter all, state rules that mandate "judicially monitored discovery,' [and] 'the Federal Rules of Evidence,' ... are frontal assaults on arbitration" (quoting AT\&T Mobility LLC v. Concepcion, 131 S. Ct. 1740, 1747 (2011))).

239. Id

240. Concepcion, 131 S. Ct. at 1748.
} tion). 
second, the Court's decision in Stolt-Nielsen undermines this discrimination theory. In that case, the Court held that an arbitrator manifestly disregarded his authority under the FAA by imposing class arbitration where the parties were silent on the issue. ${ }^{241}$ Thus, imposing class arbitration was held to be improper for reasons that had nothing to do with concerns about a state (or the courts) discriminating against arbitration. Rather, the Court concluded, "class action arbitration changes the nature of arbitration to such a degree that it cannot be presumed the parties consented to it" 242 because it eviscerates the benefits of arbitration, which include "forgo[ing] the procedural rigor and appellate review of the courts in order to realize the benefits of private dispute resolution: lower costs, greater efficiency and speed, and the ability to choose expert adjudicators to resolve specialized disputes." ${ }^{243}$ Thus, these principles in Stolt-Nielsen, which were cited in Concepcion, ${ }^{244}$ clarify the Court's reasoning: class arbitration interferes with the fundamental attributes of arbitration, irrespective of the FAA's purposes of preventing discrimination against arbitration, and neither the arbitrator nor state law may require class-wide procedures unless the parties authorize them. ${ }^{245}$

\section{d. Concepcion as Limited to Class-Waivers}

Another potential interpretation of Concepcion would limit its preemptive effects to state law rules regulating class action or class arbitration waivers. ${ }^{246}$ Such a narrow interpretation could arguably be based on the fact that the Court explicitly framed the issue in the case as

\footnotetext{
241. Stolt-Nielsen S.A. v. AnimalFeeds Int'l Corp., 559 U.S. 662, 684-85 (2010) (explaining that "a party may not be compelled under the FAA to submit to class arbitration unless there is a contractual basis for concluding that the party agreed to do so," and holding that the arbitrators' contrary conclusion was "fundamentally at war with the foundational FAA principle that arbitration is a matter of consent").

242. Id.

243. Id.

244. Concepcion, 131 S. Ct. at 1751 (quoting Stolt-Nielsen, 559 U.S. 662at 685).

245. Finally, another argument has been advanced that the Discover Bank rule might be said to have discriminated against arbitration by treating different institutions (arbitration and litigation) as if they were the same. See Hiro Aragaki, AT\&T Mobility v. Concepcion and the Antidiscrimination Theory of FAA Preemption, 4 Y.B. ARB. \& MEDIATION 39, 67 (2013) (explaining that Concepcion "helps establish that arbitration and litigation are differently situated, such that treating them exactly the same (as Discover Bank does) amounts to a type of discrimination"). This idea draws on precedent from the gender discrimination context, under which disparate treatment occurs by ignoring relevant biological differences between men and women. While there is much to say about this novel reading, Concepcion itself says very little to support it.

246. Jonathon L. Serafini, Note, The Deception of Concepcion: Saving Unconscionability After AT\&T Mobility LLC. v. Concepcion, 48 GoNZ. L. REv. 187, 212 (2012) (stating that "[t]he narrowest interpretation of Concepcion is that it only applies to cases that involve class action waivers").
} 
whether a state law rule classifying most class arbitration waivers as unconscionable was preempted by the FAA. ${ }^{247}$ Several courts like the Supreme Court of Washington have recently opined that "[w]hether Concepcion reaches beyond class arbitration procedures is subject to debate." ${ }^{248}$

Arguments for limiting Concepcion's reasoning to the class arbitration context are unpersuasive. Most significantly, nothing in the reasoning underlying the Court's decision lends itself to the interpretation that only class arbitration waivers would be affected. Rather, it appears that the Discover Bank rule was but one example of a contract defense thought to be generally applicable, but which disproportionately applied to invalidate arbitration agreements by imposing a requirement incompatible with the FAA's purposes. The Court addressed numerous similar circumstances, albeit in hypotheticals, in which "a doctrine normally thought to be generally applicable, such as duress or ... unconscionability, is alleged to have been applied in a fashion that disfavors arbitration," which could not "sensibly be reconciled" with Section 2 of the FAA. ${ }^{249}$ For example, the Court held that a state law rule invalidating arbitration agreements that do not "provide for judicially monitored discovery," would be a rule that is theoretically applicable to " "any' contract and thus preserved by $\S 2$ of the FAA," but "[i]n practice, of course, the rule would have a disproportionate impact on arbitration agreements." 250

Notably, the majority in American Express did not characterize Concepcion as tethered to class action waivers, writing simply that Concepcion "established" that "the FAA's command to enforce arbitration agreements trumps any interest in ensuring the prosecution of low-value claims," which is an interest " "unrelated' to the FAA.", "251 And even more broadly, the majority rejected the lower court's application of the effective vindication principle because it introduced a "preliminary litigating hurdle [that] would undoubtedly destroy the prospect of speedy resolution" of arbitration. ${ }^{252}$ The Court's admonition against imposing a "judicially created superstructure" that requires assessment of preliminary questions about the merits of claims, evidence required to show such claims, and costs and likely recovery of pursuing such claims in arbitra-

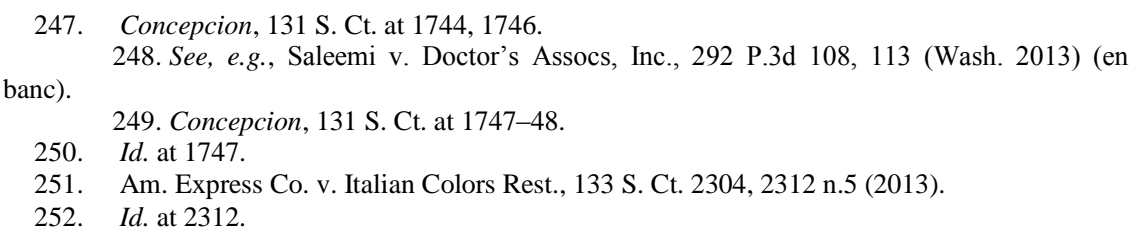


tion, has implications far beyond the class arbitration context. ${ }^{253}$

The dissent also recognized that one could not sensibly limit Concepcion to class action waivers. Justice Kagan, in her dissent in American Express, provided one of the most eloquent rebuttals to those who would limit Concepcion's preemptive effect to the class action waiver context. It could be said that Concepcion and American Express "establish what in some quarters is known as a principle," and "[t]hat principle, by its nature, operates in diverse circumstances - not just the ones that happened to come before the Court."254 In other words, other state and federal restrictions on arbitration can and do "interfere[] with fundamental attributes of arbitration," i.e., informality, efficiency, reduced costs, and speed, as much as a state rule that requires the availability of classwide arbitration. ${ }^{255}$

e. Concepcion as Limited to Rules Undermining Consent as the Basis for Arbitration

Similarly, courts could limit Concepcion's preemptive sweep to rules that implicate the principles of contractual freedom that underlie arbitration. Arbitration derives its legitimacy from the parties' consent, and the FAA's primary purpose, at least according to Volt, is to effectuate the parties' agreement. $^{256}$ Thus, it might be argued, class arbitration undermines the purposes of the FAA by binding absentees, which are not parties to the specific agreement to arbitrate. The Court in Stolt-Nielsen briefly mentioned this point, ${ }^{257}$ which recently was pressed more forcefully in Justice Alito's concurrence in Oxford Health v. Sutter. ${ }^{258}$

In Oxford Health, a unanimous Court held that an arbitrator did not manifestly disregard the parties' agreement by imposing class-wide arbitration because the parties had agreed to let the arbitrator decide the issue. $^{259}$ In their concurring opinion in Oxford Health, Justices Alito and

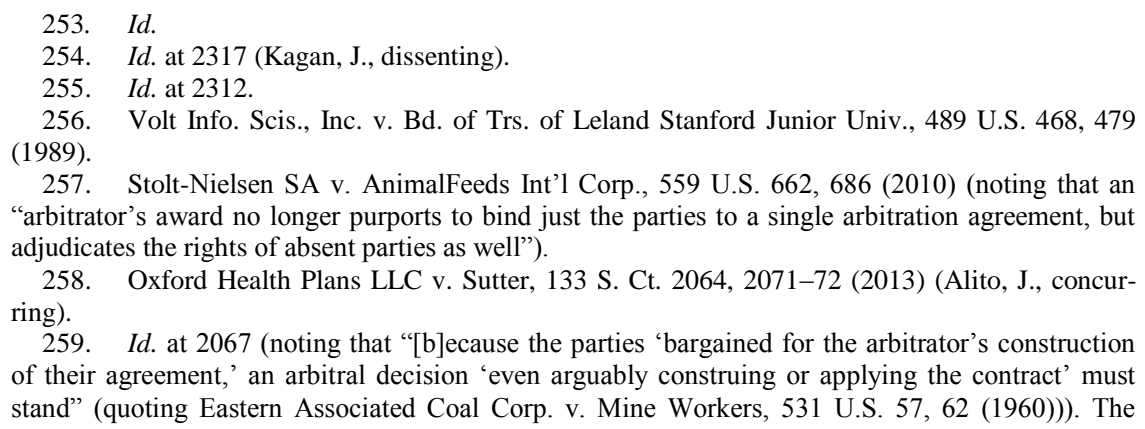

257. Stolt-Nielsen SA v. AnimalFeeds Int'l Corp., 559 U.S. 662, 686 (2010) (noting that an "arbitrator's award no longer purports to bind just the parties to a single arbitration agreement, but adjudicates the rights of absent parties as well").

258. Oxford Health Plans LLC v. Sutter, 133 S. Ct. 2064, 2071-72 (2013) (Alito, J., concurring).

259. Id. at 2067 (noting that "[b]ecause the parties 'bargained for the arbitrator's construction of their agreement,' an arbitral decision 'even arguably construing or applying the contract' must stand" (quoting Eastern Associated Coal Corp. v. Mine Workers, 531 U.S. 57, 62 (1960))). The 
Thomas appeared to view class arbitration as fundamentally incompatible with principles of consent. ${ }^{260}$ In their view, when an arbitrator decides that an agreement requires class-wide procedures, that determination cannot bind absentee parties that have not opted in, and therefore have not submitted to the arbitrator's authority. ${ }^{261}$ Moreover, "[c]lass arbitrations that are vulnerable to collateral attack allow absent class members to unfairly claim the 'benefit from a favorable judgment without subjecting themselves to the binding effect of an unfavorable one.",262 Because these issues are so fundamental to arbitration, the concurrence suggested, the arbitrator might be ill-suited to decide the issue where the parties do not require it. ${ }^{263}$

Thus, Discover Bank rule arguably conflicted with the FAA's purposes by mandating class arbitration, which undermined arbitration's basis in the consent of the parties. However, we are aware of no court limiting Concepcion in this manner; and indeed, Concepcion never fully articulated the concurrence's concerns in Oxford Health. To be sure, the Court mentioned the problems posed by absentee class members. But the tenor of that reference was that absentees were considered problematic because additional procedural formality is required to ensure their rights are adequately protected. ${ }^{264}$ Moreover, the Oxford Health concurrence, which does not even mention Concepcion, cannot explain the Court's dicta about the impropriety of judicial procedures applied to arbitration. $^{265}$ Simply put, even though there is overlap in Concepcion's analysis and the concerns about consent articulated by the concurrence in

Court in Oxford Health narrowly distinguished Stolt-Nielsen on the basis of this single fact: whether the parties consented to submit this issue of contract interpretation to the arbitrator. Id. at 2070.

260. See id. at 2071 (Alito, J., concurring) (observing that "absent members of the plaintiff class never conceded that the contract authorizes the arbitrator to decide whether to conduct class arbitration" and that the arbitrator improperly inferred that the absent parties had implicitly agreed to arbitration).

261. See id. ("[A]n arbitrator's erroneous interpretation of contracts that do not authorize class arbitration cannot bind someone who has not authorized the arbitrator to make that determination.").

262. Id. at 2072 (quoting Am. Pipe \& Constr. Co. v. Utah, 414 U.S. 538, 546-47 (1974)).

263. See id. ("In the absence of concessions [that an arbitrator should determine whether a contract approved class arbitration], this possibility should give courts pause before concluding that the availability of class arbitration is a question the arbitrator should decide.").

264. See AT\&T Mobility LLC v. Concepcion, 131 S. Ct. 1740, 1751 (2011) (discussing procedural concerns presented by class arbitration and noting that absent class members must be adequately represented and given notice and an option to opt out of the class before they can be bound by a class action judgment).

265. See, e.g., id. at 1747 (explaining that a rule refusing to enforce arbitration agreements that failed to permit judicially-monitored discovery "would have a disproportionate impact on arbitration agreements" and thus would be preempted, even though the rule "would presumably apply to contracts purporting to restrict discovery in litigation as well"). 
Oxford Health, there is no reason to believe that Concepcion rests on principles of freedom of contract or party consent.

\section{f. Concepcion as Limited to Unconscionability Rules}

Section 2 of the FAA states that arbitration agreements may be held unenforceable " "upon such grounds as exist at law or in equity for the revocation of any contract, ", ${ }^{266}$ which has been defined by the Supreme Court to include "'generally applicable contract defenses, such as fraud, duress, or unconscionability." 267 But, despite this precedent that was not explicitly overruled in Concepcion, there is now a lively debate whether the seeds of unconscionability's demise as a defense to arbitration are buried within Concepcion's reasoning.

There are ready arguments why unconscionability has survived, at least in some form, as a defense to the enforcement of an arbitration agreement. Significantly in Concepcion, Justice Scalia's plurality, Justice Thomas's concurrence, and Justice Breyer's dissent, all state that the unconscionability defense is a basis for non-enforcement of an arbitration agreement. ${ }^{268}$ Additionally, in a terse per curiam decision issued after Concepcion, the Supreme Court summarily reversed a West Virginia decision on the ground that the state court " prohibits outright the arbitration of a particular type of claim.",269 However, the Court permitted the West Virginia court to consider on remand whether, absent the state's general public policy against pre-dispute arbitration agreements for claims of personal injury or wrongful death against nursing homes, the arbitration clauses at issue were "unenforceable under state common law principles that are not specific to arbitration and pre-empted by the FAA."270 The other basis for the state court's conclusion was uncon-

\footnotetext{
266. Id. at 1746 (quoting 9 U.S.C. $\$ 2$ (2006)).

267. Id. (emphasis added) (quoting Doctor's Assocs. v. Casarotto, 517 U.S. 681, 687 (1996)).

268. Id. (Scalia, J.) (plurality opinion) (stating that $\S 2$ of the FAA "permits agreements to arbitrate to be invalidated by 'generally applicable contract defenses, such as fraud, duress, or unconscionability"); id. at 1755 (Thomas, J., concurring) (stating that "every specific contract defense that the Court has acknowledged is applicable under $\S 2$ relates to contract formation," including "unconscionability"); $i d$. at 1756-58 (Breyer, J., dissenting) (stating that the Discover Bank rule "represents the "application of a more general [unconscionability] principle," which is a ground that "'exist[s] at law or in equity for the revocation of any contract"" (quoting Gentry v. Super. Ct., 165 P.3d 556, 564 (Cal. 2007); 9 U.S.C. § 2 (2006))).

269. Marmet Health Care Ctr., Inc. v. Brown, 132 S. Ct. 1201, 1203-04 (2012) (quoting Concepcion, 131 S. Ct. 1740, 1747 (2011)).

270. Id. at 1204 .
} 
scionability. ${ }^{271}$ Finally, some lower federal courts, like the Ninth Circuit, have concluded that "Concepcion did not overthrow the common law contract defense of unconscionability ... [r]ather, the [U.S. Supreme] Court reaffirmed [it] . . . so long as those doctrines are "not applied in a fashion that disfavors arbitration." "272 Several other federal courts of appeals appear to also be in accord. ${ }^{273}$

However, commentators have cautioned that a broad interpretation of Concepcion may actually "eliminate[] unconscionability as a defense for arbitration agreements completely," 274 or that the decision "cast[s] doubt on the continued application of [FAA] section 2 contract law defenses, specifically unconscionability." 275 And, at least one court appears to have held that public policy and unconscionability are no longer grounds upon which a court may refuse to enforce an arbitration agreement, while "[o]ther contract principles under state law, such as those governing the formation and interpretation of an agreement, may still pertain." 276

An argument that Concepcion threatens to undermine unconscionability as a state law defense to arbitration would likely draw on the Court's statement that while generally applicable contract defenses are preserved in Section 2 of the FAA, "nothing in it suggests an intent to preserve state-law rules that stand as an obstacle to the accomplishment of the FAA's objectives."277 Those objectives were broadly defined in Concepcion, which accordingly would result in the preemption of state law unconscionability rules, like the Discover Bank rule, that had the effect of requiring a process that was less efficient, or more formal, than

271. See Brown v. Genesis Healthcare Corp., 729 S.E.2d 217, 230 (W. Va. 2012) (remanding to the trial court for fact-finding under West Virginia's general unconscionability doctrine).

272. Kilgore v. KeyBank, Nat'l Ass'n, 673 F.3d 947, 963 (9th Cir. 2012) (quoting Concepcion, 131 S. Ct. at 1747).

273. See, e.g., In re Checking Account Overdraft Litig., 685 F.3d 1269, 1279 (11th Cir. 2012) (concluding that "South Carolina's unconscionability doctrine does not 'interfere[] with fundamental attributes of arbitration' as identified by the Supreme Court, and is among the 'generally applicable contract defenses' that apply to arbitration agreements under the savings clause of 9 U.S.C. $§ 2$ " (internal citation omitted) (quoting Concepcion, $131 \mathrm{~S}$. Ct. at 1746-48)); see also Litman v. Cellco P'ship, 655 F.3d 225, 230-32 (3d Cir. 2011) (including unconscionability as a "generally applicable contract defense" post-Concepcion, but holding that New Jersey law that waivers of class arbitration are unconscionable is inconsistent with the FAA and therefore pre-empted).

274. Serafini, supra note 246, at 215.

275. Maureen A. Weston, The Death of Class Arbitration After Concepcion?, 60 U. KAN. L. Rev. 767, 786 (2012); see also Stephen E. Friedman, A Pro-Congress Approach to Arbitration and Unconscionability, 106 Nw. U. L. REV. ColloQuY 53, 53-54 (2011) ("While Concepcion sanctions the continued theoretical applicability of unconscionability to arbitration provisions, it leaves very little room for the actual application of the doctrine.").

276. NAACP of Camden Cnty. E. v. Foulke Mgmt. Corp., 24 A.3d 777, 791-92 (N.J. Super. Ct. App. Div. 2012).

277. AT\&T Mobility LLC v. Concepcion, 131 S. Ct. 1740, 1748 (2011). 
the Court's general notion of arbitration. ${ }^{278}$ At a high level of abstraction, unconscionability rules level the playing field between disputing parties of unequal bargaining power. Thus, there is good reason to believe that, at least as those rules relate to arbitration, they will tend to result in more process, not less. The flipside of that coin is that unconscionability rules tend to sacrifice efficiency and thus fall afoul of Concepcion's logic.

In conjunction with Concepcion, the Court's decision in American Express casts a long shadow over the doctrine of unconscionability as a defense to arbitration agreements. ${ }^{279}$ Undeniably, the Court took a very narrow view of the federal "effective vindication" of rights principle, asking only whether a contested term of arbitration operated to waive, or eliminate, a party's "right to pursue statutory remedies." 280 So, while a contract could not directly prevent a party from bringing a federal cause of action, the take-away from American Express is that the terms of the arbitration agreement could ensure that the costs of proving the claim would exceed any remedy. ${ }^{281}$

States define unconscionability in many ways. All require substantive unconscionability, which looks into the fairness of the terms of the contract. $^{282}$ In a typical formulation, a contract term is held to be substantively unconscionable if it is "so one-sided that it shocks the conscience," 283 or if it would be "grossly unreasonable" to enforce terms that are "unreasonably favorable to the other party." 284 The American Express majority, however, rebuked the Second Circuit for employing an analysis (the federal effective-vindication analysis) before enforcing the arbitration agreement, which required a claim-by-claim, theory-by-theory

278. See id. at 1751 (noting that the FAA avoids "the switch from bilateral to class arbitration[, which] sacrifices the principal advantage of arbitration-its informality - and makes the process slower, more costly, and more likely to generate procedural morass than final judgment").

279. See Am. Express Co. v. Italian Colors Rest., 133 S. Ct., 2304, 2312 (2013).

280. Id. at 2310-11.

281. See id. at 2311 ("[T] he fact that it is not worth the expense involved in proving a statutory remedy does not constitute the elimination of the right to pursue that remedy."). The Court in American Express interprets the term "waiver" literally, so as to mean that a party may not attempt to insert into an arbitration agreement a provision "forbidding the assertion of certain [federal] statutory rights." Id. at 2310.

282. State ex rel. Richmond Am. Homes of W. Va. v. Sanders, 717 S.E.2d 909, 921 (W. Va. 2011). By contrast, procedural unconscionability refers to the unfairness in the bargaining process leading to the formation of the contract, as by for example, limitations on a party's ability to understand contract terms, or a company's providing contract terms on a take-it-or-leave-it basis. See id. at 920 .

283. Pinnacle Museum Tower Assn. v. Pinnacle Mkt. Dev. (US), LLC, 282 P.3d 1217, 1233 (Cal. 2012)

284. King v. Fox, 851 N.E.2d 1184, 1191 (N.Y. 2006). 
review of plaintiff's claims, the evidence necessary to prove such claims, and the costs and likely recompense if the plaintiff was ultimately successful. ${ }^{285}$ State law unconscionability analysis of an arbitration agreement similarly weighs the fairness to the plaintiff for each of the myriad of aspects of the dispute resolution process in which the plaintiff has agreed to participate, all in advance of the plaintiff's participation in that process. ${ }^{286}$ Like the effective vindication of rights analysis, as employed by the Second Circuit, state law unconscionability could be considered a "preliminary litigation hurdle" or a "judicially created superstructure" that would "destroy the prospect of speedy resolution that arbitration in general and bilateral arbitration in particular was meant to secure."287

At the very least then, state unconscionability law is suspect to the extent it relies on effective vindication principles. While it appears that Concepcion and American Express will cause courts to look at unconscionability challenges with a more skeptical eye, one must take the Court at face value that the general defense survives. Thus, if state unconscionability decisions are to survive a challenge of FAA preemption, there must be facts showing unfairness above and beyond what has been required under the effective vindication test. How egregious such facts must be remains an open question.

\section{Concepcion Unplugged}

"Concepcion is broadly written.,"288 It is not limited in its application to federal courts, to its facts, to class action waivers, or even to state unconscionability doctrine. As explained above, such limitations on the scope of Concepcion are artificial, because the Court's analysis in the case makes it clear that these were not material considerations, as confirmed by the weight of subsequent precedent.

Numerous courts have recognized that Concepcion added the fundamental attributes approach as a third prong to the Court's test for invalidating state law restrictions on arbitration. ${ }^{289}$ For example, the Eleventh

\footnotetext{
285. Am. Express, 133 S. Ct. at 2310-12 (2013).

286. Id.

287. Id. at 2312 .

288. Coneff v. AT \& T Corp., 673 F.3d 1155, 1158 (9th Cir. 2012).

289. See, e.g., Walker v. BuildDirect.com Techs., Inc., No. 12-6261, 2013 WL 4106341, at *3 (10th Cir. Aug. 15, 2013). See also In re Checking Account Overdraft Litig., 685 F.3d 1269, 1277 (11th Cir. 2012); Coneff, 673 F.3d at 1158 (explaining that "a state court impermissibly relies on the uniqueness of an agreement to arbitrate" when the court "requir[es] arbitration to maintain procedures fundamentally at odds with its very nature" (internal grammatical marks omitted)).
} 
Circuit upheld South Carolina's unconscionability doctrine when it was applied to refuse enforcement of an arbitration clause. First, the court held that the South Carolina unconscionability doctrine "applies to arbitration and to other agreements according to the same basic criteria, and these criteria do not disproportionately impact arbitration agreements." 290 And second, the court concluded that the unconscionability doctrine "does not interfere with fundamental attributes of arbitration as identified by the Supreme Court," and notably, did not sacrifice "procedural informality that Concepcion recognized as the principal advantage of arbitration."291 Significantly, the Court in American Express characterized the holding in Concepcion in a very broad manner, emphasizing only the fundamental attributes portion of the Court's analysis and thus dispelling any notion that the pro-consumer nature of the arbitration agreement or other facts in Concepcion were material to that decision. ${ }^{292}$

\section{THE CONSEQUENCES OF CONCEPCION: STATE LAW}

Concepcion has emboldened drafters to challenge state statutes, contract defenses, and other common law rules that purportedly interfere with the "fundamental attributes of arbitration." Courts are just now beginning to address the argument - in a dizzying variety of contexts - that the FAA preempts state laws that may render arbitration more formal, costlier, or less efficient. Most courts have read Concepcion as broadly as we have. Thus, few bright lines have emerged to shield state laws from a Concepcion-based challenge, as would have been possible under a narrower interpretation.

\section{A. Consequences for State Law Hostile to Arbitration}

\section{State Law Based on Unconscionability}

In determining the enforceability of an arbitration clause, a court applies ordinary state law principles governing the formation of all contracts $^{293}$ and may refuse to enforce arbitration clauses on the basis of "generally applicable contract defenses, such as fraud, duress, or uncon-

\footnotetext{
290. In re Checking Account Overdraft Litig., 685 F.3d at 1277.

291. Id. at 1279 (internal grammatical marks and citations omitted).

292. Am. Express, 133 S. Ct. at 2311-12.

293. See Davis v. O’Melveny \& Myers, 485 F.3d 1066, 1072 (9th Cir. 2007) (citation omitted) (analyzing California law to determine enforceability based on procedural and substantive unconscionability).
} 
scionability." 294 While litigants are free to challenge arbitration clauses on those and other grounds, we first address the implications of Concepcion to state unconscionability doctrine since litigants increasingly rely on unconscionability as a basis to challenge arbitration clauses. ${ }^{295}$ Many states share certain core unconscionability principles, and therefore, one can draw general conclusions about Concepcion's impact on state unconscionability law despite the nuances of that doctrine among the states.

Under California law, for instance, any contract term including an arbitration clause is unenforceable if it is both procedurally and substantively unconscionable. ${ }^{296}$ This determination requires courts to use "a sliding scale"- " "the more substantively oppressive the contract term, the less evidence of procedural unconscionability is required to come to the conclusion that the term is unenforceable, and vice versa." "297 Both forms of unconscionability are required before a court can "exercise its discretion to refuse to enforce a contract or clause under the doctrine of unconscionability.",298 California unconscionability law, like many other states, places the burden on the party arguing unconscionability as a defense to show its applicability. ${ }^{299}$

The California Supreme Court's historic decision in Armendariz v. Foundation Health ${ }^{300}$ represents perhaps the most far-reaching application of state unconscionability law in the arbitration context. The court in Armendariz crafted a per se rule under which, to be enforceable, an arbitration agreement must (1) include a mutual agreement to arbitrate; ${ }^{301}$ (2) provide for adequate discovery; ${ }^{302}$ (3) not impose costs on the employee that the employee would not normally bear in court; ${ }^{303}$ (4) provide

\footnotetext{
294. AT\&T Mobility LLC v. Concepcion, 131 S. Ct. 1740, 1746 (2011) (quoting Doctor's Assocs., Inc. v Casarotto, 517 U.S. 681, 687 (1996)).

295. See, e.g., Steven J. Burton, The New Judicial Hostility to Arbitration: Federal Preemption, Contract Unconscionability, and Agreements to Arbitrate, 2006 J. DISP. RESOL. 469, 485-86 (stating that "since 2000, many courts have been refusing to enforce arbitration agreements," and that "[t]he usual ground for such refusals is unconscionability"); Susan Randall, Judicial Attitudes Toward Arbitration and the Resurgence of Unconscionability, 52 BUFF. L. REV. 185, 194-95 (2004) (concluding based on an examination of a certain dataset that in 1982-83, only in one case was an arbitration agreement held unconscionable, while in 2002-03, thirty-two arbitration agreements were held unconscionable).

296. See Concepcion, 131 S.Ct. at 1746 (citing Armendariz v. Found. Health Psychcare Servs., Inc., 6 P.3d 669 (2000)).

297. Armendariz, 6 P.3d at 690

298. Id.

299. See Higgins v. Super. Ct., 45 Cal. Rptr. 3d 293 (Cal. Ct. App. 2006) (citation omitted).

300. Armendariz, 6 P.3d 669 (Cal. 2000).

301. Id. at 692 .

302. Id. at 683 .

303. Id. at 687.
} 
for selection of a neutral arbitrator; ${ }^{304}$ and (5) comply with several other similar fairness requirements. ${ }^{305}$

While at least one California court has held that Armendariz remains good law after Concepcion, ${ }^{306}$ that court's analysis was based on the cursory reason that Concepcion did not strike down unconscionability as a generally-applicable contract defense. ${ }^{307}$ In effect, the court unconvincingly side-stepped Concepcion's preemption analysis, which provides that a generally applicable state contract defense such as unconscionability is preempted by the FAA if it targets arbitration for disfavored treatment, or presents an obstacle to the fundamental attributes of arbitration. As in Concepcion, courts must unpack the basis for the state law unconscionability ruling and determine whether that basis (such as requiring adequate discovery) targets arbitration for disfavored treatment or otherwise interferes with the fundamental attributes of arbitration. Therefore, aspects of the per se rule in Armendariz likely do not stand up to Concepcion's underlying reasoning, as discussed more fully below. ${ }^{308}$

\section{State Law Based on Federal Common Law}

In addition to relying on the sources of state law addressed above, some courts also have found arbitration agreements unconscionable under state law, relying, oddly enough, on federal common law principles. State courts have cited Mitsubishi and Randolph for the proposition that a court may refuse to compel arbitration if arbitration costs are so onerous that a litigant effectively would be prevented from pursuing a claim under state law (instead of federal law). ${ }^{309}$ Mitsubishi and Randolph

\footnotetext{
304. Id. at 682 .

305. See, e.g., id. at 683 (concluding that the damages and remedies limitation was "contrary to public policy and unlawful").

306. Samaniego v. Empire Today LLC, 140 Cal. Rptr. 3d 492, 495 (Cal. Ct. App. 2012) (finding the disputed provision to be "unconscionable and unenforceable under Armendariz").

307. Id. at 502 (interpreting Concepcion to "reaffirm[] that the FAA "permits agreements to arbitrate to be invalidated by generally applicable contract defenses, such as ... unconscionability", (citing AT\&T Mobility LLC v. Concepcion, 131 S. Ct. 1740, 1746 (2011))).

308. See Horton, Federal Arbitration Act Preemption, supra note 27, at 1244 (noting that several courts have questioned whether portions of the Armendariz rule are still "good law," because "the Armendariz requirements, though couched in terms of unconscionability, cannot be described as grounds that 'exist at law or in equity for the revocation of any contract"' (quoting James v. Conceptus, Inc., 851 F. Supp. 2d 1020, 1033 (S.D. Tex. 2012))).

309. See, e.g., Gandee v. LDL Freedom Enters., Inc., 293 P.3d 1197, 1200 (Wash. 2013) (citing Randolph in support of the prohibitive-cost defense and concluding that "sufficient evidence was presented to make a prima facie case for a prohibitive-cost defense" because the "costs of arbitrating in California would exceed [the plaintiff's] claim" (citing Green Tree Fin. Corp.-Ala. v. Randolph, 531 U.S. 79 (2000)); see also Armendariz, 6 P.3d at 680 (citing Mitsubishi for the proposition that,
} 
have not been explicitly overruled; however, after Concepcion, state court rulings risk preemption by relying on these two cases to refuse to enforce an arbitration agreement solely in the context of state law claims.

Prior to Concepcion, courts were divided over whether Mitsubishi and Randolph spoke to the validity of arbitration agreements implicating only state law claims. For example, the Eighth Circuit held that "[a] feesplitting arrangement may be unconscionable if information specific to the circumstances indicates that fees are cost-prohibitive and preclude the vindication of statutory rights in an arbitral forum," citing Randolph. $^{310}$ The Eleventh Circuit also purported to employ state unconscionability doctrine but instead relied on the "vindication of statutory rights" rationale. ${ }^{311}$ The First Circuit took a slightly different view, explaining that state unconscionability necessarily includes a vindication of rights inquiry, but noting that state law considers additional factors. ${ }^{312}$ Thus conceived, if an arbitration agreement was unconscionable under state contract law, it necessarily would have violated the vindication of rights inquiry as well. By contrast, the Sixth Circuit held that the vindication of statutory rights doctrine could not inform arbitrability under state law whatsoever, as such doctrinal cross-talk would violate the Erie doctrine. ${ }^{313}$ Therefore, courts have recognized the considerable overlap between state unconscionability law and the vindication of statutory rights doctrine, but no uniform analysis emerged in this context.

Concepcion requires a critical rethinking of precedent that relies on the Mitsubishi and Randolph line of cases to hold that cost prohibitiveness is a defense to arbitration when only state law claims are at issue. ${ }^{314}$ While the issue of prohibitive arbitration costs is addressed in greater de-

by agreeing to arbitrate a California statutory claim, a party has not agreed to forego rights afforded by the statute but only to submit to their resolution in arbitration (citing Mitsubishi Motors Corp. v. Soler Chrysler-Plymouth, Inc., 473 U.S. 614 (1985))).

310. Faber v. Menard, Inc., 367 F.3d 1048, 1053 (8th Cir. 2004); accord Murray v. United Food \& Commercial Workers Int'l Union, 289 F.3d 297, 303 (4th Cir. 2002) (applying unconscionability analysis regarding federal cause of action).

311. Jenkins v. First Am. Cash Advance of Ga., LLC, 400 F.3d 868, 877-79 (11th Cir. 2005).

312. Kristian v. Comcast Corp., 446 F.3d 25, 60 n.22 (1st Cir. 2006) ("We realize that a state unconscionability analysis, based on the particulars of state contract law, may include considerations not present in the vindication of statutory rights analysis applied here, which is not dependent on state law. However, the unconscionability analysis always includes an element that is the essence of the vindication of statutory rights analysis - the frustration of the right to pursue claims granted by statute.").

313. Stutler v. T.K. Constructors Inc., 448 F.3d 343, 345-47 (6th Cir. 2006).

314. See, e.g., In re Poly-America, L.P., 262 S.W.3d 337, 355 (Tex. 2008) (brought under a Texas statute and citing Randolph for the proposition that courts have "condemned the use of feesplitting agreements in employment contracts that have the effect of deterring potential litigants from vindicating their statutory rights in an arbitral forum"). 
tail later, we offer some initial thoughts about why this federal common law authority is no longer permissible in the post-Concepcion era for FAA preemption purposes.

First, Mitsubishi and Randolph addressed circumstances in which the interest in vindicating a federal statutory right conflicted with the federal interest in enforcing arbitration agreements. ${ }^{315}$ In contrast to Concepcion or any case involving only state law claims, Mitsubishi and Randolph did not raise any FAA preemption issues. The federal common law principles in Mitsubishi and Randolph and the obstacle preemption principles in Concepcion derive from different sources: the former seek to clarify federal law, whereas the latter seek to establish the supremacy of federal law. ${ }^{316}$

Moreover, state unconscionability law and federal common law are not coextensive. ${ }^{317}$ State unconscionability law survives Concepcion and American Express, but, as we have noted elsewhere, American Express renders the effective vindication of rights doctrine largely toothless. ${ }^{318}$ Thus, state unconscionability law must require a heightened showing of unfairness above and beyond that which was required under the preAmerican Express vindication of rights doctrine.

Lastly, and most significantly, Concepcion likely upsets courts' reliance on Mitsubishi and Randolph for the proposition that arbitration agreements need not be enforced when state law claims otherwise may not be vindicated. ${ }^{319}$ This is because in Concepcion, the Court (1) rejected the proposition that a state can require a procedure inconsistent with the FAA even if it might be necessary to ensure the vindication of small-

315. See Green Tree Fin. Corp.-Ala. v. Randolph, 531 U.S. 79, 89 (2000); Mitsubishi Motors Corp. v. Soler Chrysler-Plymouth, Inc., 473 U.S. 614, 652 (1985); $c f .14$ Penn Plaza LLC v. Pyett, 556 U.S. 247, 273 (2009).

316. See, e.g., Orman v. Citigroup, Inc., No. 11 Civ. 7086(DAB), 2012 WL 4039850, at *3 (S.D.N.Y. Sept. 12, 2012) ("Indeed, the [federal] vindication of statutory rights doctrine has its origins in principles of statutory interpretation and is derived from an inference that Congress did not intend to preempt rights it had created in other federal statutes when it passed the FAA. Thus there is no principled reason to apply the doctrine to bar arbitration of claims grounded in state laws which were not created by Congress.").

317. E.g., Kristian v. Comcast Corp., 446 F.3d 25, 60 n.22.

318. See supra Part I.B.2.

319. See, e.g., Dean v. Draughons Junior Coll., Inc., 917 F. Supp. 2d 751, 762 (M.D. Tenn. 2013) (because Mitsubishi and Randolph involved "a body of federal substantive law developed by the Court specifically to address situations in which the interest in vindicating federal statutory rights conflicts with the federal interest in enforcing arbitration agreements," reliance on these cases in the context of state law claims was a defense "not applicable to 'any' contract" and thus was preempted by Section 2 of the FAA); Orman, 2012 WL 4039850, at *3 (noting that the court "cannot identify any cases in which a vindication of statutory rights analysis under the FAA has been applied to state statutory claims"). 
dollar state law claims; ${ }^{320}$ and (2) clarified that state courts cannot apply even a generally applicable contract defense if applied in a manner that discriminates against arbitration. ${ }^{321}$ The cost-prohibitiveness defense is not even a generally applicable contract defense because it is framed as a specific defense to arbitration. And in any event, ensuring financially reasonable arbitration costs overlaps substantially with the policy, already rejected by the Court, that ensuring the prosecution of small-dollar state law claims is a basis to deviate from the FAA's purposes. We therefore expect to see the drafter's argument - that Mitsubishi, Randolph, and other federal common law cases do not support state court decisions refusing to enforce arbitration agreements-prevail in Concepcion's wake.

It should be noted, however, that although federal common law may not be coextensive with state law, and federal law lacks binding effect with respect to purely state law issues, it still may serve as persuasive authority. The vindication of rights test strikes on public policy themes similar to those found in state unconscionability law. If the First Circuit is correct, and federal common law is a logical subset of state unconscionability law, then (a) a decision upholding arbitrability on federal common law grounds would be dispositive as to state contract law, and (b) a decision denying arbitrability under federal law would be persuasive, but not dispositive, authority under state law. ${ }^{322}$

Given Concepcion's clear mandate and Randolph's diminishing significance, courts will face the unsavory prospect between finding state law preempted or circumventing Concepcion by relying on the gross unfairness of the arbitration agreement. The Ninth Circuit's recent decision in Chavarria v. Ralph's Grocery Store illustrates the conceptual difficulties in denying a motion to compel arbitration under these circumstances. ${ }^{323}$ In Chavarria, the agreement at issue-compelled as a basis for employment - effectively gave the employer unbridled discretion to select the arbitrator. ${ }^{324}$ Moreover, the agreement eschewed institutional arbitration rules that provided for a neutral arbitrator. ${ }^{325}$ Finally, the policy

\footnotetext{
320. AT\&T Mobility LLC v. Concepcion, 131 S. Ct. 1740, 1753 (2011).

321. Id. at 1748 .

322. See Kristian, 446 F.3d at 60 n.22 ("We realize that a state unconscionability analysis, based on the particulars of state contract law, may include considerations not present in the vindication of statutory rights analysis applied here, which is not dependent on state law. However, the unconscionability analysis always includes an element that is the essence of the vindication of statutory rights analysis - the frustration of the right to pursue claims granted by statute.").

323. Chavarria v. Ralphs Grocery Co., 733 F.3d 916, 919 (9th Cir. 2013).

324. Id. at 920 .

325. Id.
} 
required that the arbitrator apportion arbitration fees equally on the parties up front, before resolving the merits of the claims, irrespective of state law to the contrary. ${ }^{326}$ The Ninth Circuit panel held that the provision was unconscionable and that Concepcion did not preempt that application of state law. ${ }^{327}$ First, the panel reasoned that the agreement imposed prohibitive costs under Randolph. ${ }^{328}$ Second, it found preemption inapplicable because state law did not target arbitration for unfavorable treatment. ${ }^{329}$ The panel's analysis, however, is problematic, first and foremost, because Randolph is no longer persuasive in the context of FAA preemption, as discussed above. Moreover, the panel ignored that a facially neutral state law may still interfere with the FAA's fundamental attributes. Simply put, it is unclear how Concepcion permits a court to deny arbitration even where the provision appears to be unusually harsh.

\section{B. Recurring State Preemption Issues}

\section{State Procedural Law}

Prior to Concepcion, most state courts had rejected various preemption challenges on the ground that the FAA does not preempt state procedural law. ${ }^{330}$ Such courts repeatedly held that the FAA does not "require submission to federal procedural law." 331 In other words, "[e]ach state is free to apply its own procedural requirements so long as those procedures do not defeat the purposes of the act." ${ }^{\text {"32 }}$ These decisions may note, for example, that the FAA does not preempt state procedural law because such law "does not go to the essence of the arbitration

\footnotetext{
326. Id. at 920-21.

327. Id. at 927 .

328. Id. at $925-26$.

329. Id. at 927.

330. See Pierre H. Bergeron, District Courts As Gatekeepers? A New Vision of Appellate Jurisdiction over Orders Compelling Arbitration, 51 EMORY L. J. 1365, 1387-88 (2002) (noting that the majority rule in state courts is that the FAA does preempt a neutral state procedural law); see also Alan Scott Rau, Federal Common Law and Arbitral Power, 8 Nev. L. J. 169, 195 n.86 (2008) (noting that most courts follow the rule that state procedural law is not preempted by the FAA).

331. See, e.g., Bison Bldg. Materials, Ltd. v. Aldridge, No. 06-1084, 2012 WL 3870493, at *3 (Tex. Aug. 17, 2012) ("Although the FAA governs the dispute, federal procedure does not apply in Texas courts, even when Texas courts apply the FAA." (internal quotation marks and citation omitted)); Scharf v. Kogan, 285 S.W.3d 362, 369 (Mo. Ct. App. 2009) (stating that because "the FAA applies, and we must apply federal law ... Missouri procedural law applies, so long as the applicable Missouri procedures do not defeat rights granted by Congress"); So. Cal. Edison Co. v. Peabody Western Coal, 977 P.2d 769, 773 (Ariz. 1999) (stating the FAA does not "require submission to federal procedural law"); see also Felder v. Casey, 487 U.S. 131, 138 (1988) (recognizing that states may establish procedural rules governing litigation in their own courts).

332. So. Cal. Edison Co., 977 P.2d at 773-74.
} 
agreement, nor are parties likely to address it in their arbitration agreement." 333 By contrast, a minority of courts do not dwell on the substance-procedure distinction. Rather, they stress that state rules may contravene the purpose and effect of the FAA no matter their classification as procedural or substantive.

The substance-procedure distinction is not useful in the FAA preemption context. ${ }^{334}$ Denominating a state law as procedural or substantive begs the question. Indeed, as in other contexts, the line between procedure and substance is not clean. ${ }^{335}$ Even if, for example, a state law rule governing appeals from decisions compelling arbitration is considered a procedural matter, it has substantive spillover effects. These spillover effects, for instance, may subject a defendant to a significantly higher risk of liability. Such spillover effects may be heightened where state law differs from relevant federal law on issues including: the burden of proof, the propriety of a derivative instead of direct action, the statute of limitations, punitive damages, abstention pending parallel litigation, and so forth.

After Concepcion, the substance-procedure distinction is even less likely to shield from preemption state laws that impede the purposes of the FAA. For one, the Discover Bank class arbitration rule invalidated in Concepcion was arguably procedural, yet this did not factor into the

333. Drahozal, supra note 41, at 424. See also Michael L. Taviss, Comment, Adventures in Arbitration: The Appealability Amendment to the Federal Arbitration Act, 59 U. CIN. L. REv. 559, 580-82 (1990) (" "I]t is highly unlikely that section 15 can preempt state arbitration appeals statutes. The legislative history stated that the amendment's purpose was 'to improve the appellate process in the Federal courts of appeals with respect to arbitration."); id. at 582 ("The possibility of using state courts to circumvent section 15 does not impair the section's operation. ... Further, access to state appellate courts does not guarantee that the courts will hear the appeal, or that it will succeed. Therefore, the state court alternatives do not threaten section 15 , and may even reinforce its policy goals - increased understanding and acceptance of arbitration.").

334. See, e.g., Nagareda, supra note 39, at 1077 (noting that "[u]nder the FAA counterpart to the Erie doctrine, the question becomes not the formal, categorical one of 'substance' versus 'procedure," but rather a "functional" analysis of the arbitration clause "in real-world, operational terms"); James C. Dunkelberger, Note, Between a Rock and a Hard Place: The Plight of Health Care Arbitration Agreements under Federal Law, 2010 BYU L. REV. 1869, 1895 (stating that the distinction between substance and procedure on the issue whether a state statute is preempted by the FAA "may be wholly academic and redundant").

335. See, e.g., Shady Grove Orthopedic Assocs. v. Allstate Ins. Co., 130 S. Ct. 1431, 1447 (2010) ("Instead of a single hard question of whether a Federal Rule regulates substance or procedure, that approach will present hundreds of hard questions, forcing federal courts to assess the substantive or procedural character of countless state rules that may conflict with a single Federal Rule. And it still does not sidestep the problem it seeks to avoid. At the end of the day, one must come face to face with the decision whether or not the state policy (with which a putatively procedural state rule may be 'bound up') pertains to a 'substantive right or remedy,'... that is, whether it is substance or procedure." (internal footnote and citation omitted)). 
Court's preemption analysis. ${ }^{336}$ Class actions under Federal Rule of Civil Procedure 23 have been viewed as "arguably procedural" under the Erie doctrine, and federal courts accordingly use this rule in diversity actions. $^{337}$

The majority opinion in Concepcion contained significant clues that the Court viewed the Discover Bank rule as a procedural rule. In fact, Justice Scalia framed the threshold issue in this manner: "We consider whether the FAA prohibits States from conditioning the enforceability of certain arbitration agreements on the availability of classwide arbitration procedures. ${ }^{, 338}$ Later, the Court concluded that class arbitration required by the Discover Bank rule was "more likely to generate procedural morass than final judgment." 339 Finally, the Court clearly indicated that the substance-procedure distinction was not material to the FAA preemption analysis by stating that the FAA embodies "a liberal federal policy favoring arbitration agreements, notwithstanding any state substantive or procedural policies to the contrary." 340

The Court earlier had suggested in Volt that state procedural rules that merely determined the efficient order of proceedings, even resulting in delay, did not "undermine the goals and policies of the FAA."341 Although Volt technically was not a preemption case, instead turning on enforcement of the parties' agreement, the Court's dicta gave state courts license to invalidate arbitration agreements that failed to comply with matters of procedure. But procedural rules, like substantive rules, can and do "interfere[] with fundamental attributes of arbitration" as stated in Concepcion, by increasing its formality, or "making it slower or more costly." "342 Cases like Ferrer and Mastrobuono recognized the point even before Concepcion limited Volt by adopting a presumption against construing arbitration agreements to incorporate inefficient state law. ${ }^{343}$ After Concepcion, courts and litigants would be well advised to take a cautious approach to the substance-procedure distinction, considering that Volt's reasoning on this point likely no longer remains viable. In any

\footnotetext{
336. See, e.g., id. at 1437 ("[T]he Court of Appeals held that $\S 901(\mathrm{~b})$ is 'substantive' within the meaning of Erie.").

337. Hanna v. Plumer, 380 U.S. 460, 476-78 (1965) (Harlan, J., concurring)

338. AT\&T Mobility LLC v. Concepcion, 131 S. Ct. 1740, 1744 (2011) (emphasis added)

339. Id. at 1751 (emphasis added).

340. Id. at 1749 (quoting Moses H. Cone Mem'l Hosp. v. Mercury Const. Corp., 460 U.S. 1, 24 (1983)).

341. Volt Info. Scis., Inc. v. Bd. of Trs. of Leland Stanford Junior Univ., 489 U.S. 468, 478 (1989).

342. Concepcion, 131 S. Ct. at $1748,1751$.

343. Id. at 1753
} 
event, rather than relying on the panacea that the FAA does not impact state procedural rules, one should consider whether the fundamental attributes of arbitration are promoted, or undermined by, the state procedural rule. ${ }^{344}$

\section{Appeals from Arbitration Orders}

Many state laws allow interlocutory appeals after a court has compelled arbitration. Many other state laws impose procedural requirements on parties seeking to appeal a court's decision refusing to compel arbitration. Both sets of laws are vulnerable after Concepcion. Indeed, one appeals court stated that the issue of whether such laws were preempted by the FAA was "likely to recur," and that such laws "present[ed] a conflict" with Concepcion. ${ }^{345}$

State arbitration statutes are modeled after the 1956 Uniform Arbitration Act (UAA). The UAA, however, has "not filled the voids left by the FAA in any systematic or consistent fashion." 346 There is no dispute that both the FAA and the UAA permit an appeal from a court order denying a motion to compel arbitration. ${ }^{347}$ That does not mean, however, that the FAA and UAA appeal procedures are identical, and whether conflicting state laws are preempted by the FAA promises to be a legal battleground.

Section 16 of the FAA generally does not permit a party to immediately appeal an order compelling arbitration, unless it is a final order, or unless the district court certifies an interlocutory appeal. ${ }^{348}$ In the state court context, by contrast, Section 19 of the UAA specifies when an appeal may be taken, and orders compelling arbitration simply are not listed as appealable. ${ }^{349}$

\footnotetext{
344. Concepcion may operate to establish a rule that flips the Erie doctrine rule on its head: a state law that is "purely procedural" would not be subject to FAA preemption, but if it is "arguably substantive," FAA preemption would be in play. Because the Erie doctrine was animated out of respect for state law, such a shift would herald an unintended sea change in courts' approach to federalism.

345. Wisconsin Auto Title Loans Inc. v. Jones, No. 2011AP2482, 2013 WL 425449 (Wis. Ct. App. Feb. 5, 2013) (unpublished certification order to the Wisconsin Supreme Court) (citation omit-

346. Stephen L. Hayford \& Alan R. Palmiter, Arbitration Federalism: A State Role in Commercial Arbitration, 54 FLA. L. REV. 175, 179 (2002).

347. See 9 U.S.C. § 16(a)(1)(C) (2006); U.A.A. § 19(a)(1) (1956).

348. See 9 U.S.C. § 16(a)(3), (b)(2) (2006); see also In re Pisgah Contractors, Inc., 117 F.3d 133, 136 (4th Cir. 1997) (holding that the FAA "contemplate[s] the immediate review of a decision favoring arbitration in only two circumstances: (1) when the district court's order represents 'a final decision with respect to an arbitration,' and (2) when 28 U.S.C. § 1292(b) provides the means for an interlocutory appeal" (internal citations omitted)).
} ted).

349. See, e.g., U.A.A. § 19 (1956); N.D. CENT. CODE § 32-29.3-28 (2003). 
With little statutory guidance, UAA jurisdictions are divided on the issue of whether orders compelling arbitration are appealable. Many states allow such appeals, presenting a possible conflict with the FAA. ${ }^{350}$ Others do not, avoiding any potential FAA conflict. ${ }^{351}$

The weight of authority has held that Section 16 of the FAA does not preempt state laws addressing interlocutory appeals. ${ }^{352}$ The majority rule relies on the proposition that the FAA does not preempt state procedural law. A minority of jurisdictions have held otherwise - that the FAA does preempt state law procedure on interlocutory appeals. ${ }^{353}$

The distinction between the availability for appeals of orders denying

350. See, e.g., ARIZ. Rev. Stat. Ann. § 12-2101.01 (2003); CAL. Civ. Proc. Code $§ 1294$ (West 2007); Colo. Rev. Stat. AnN. § 13-22-228 (West 2005); Fla. Stat. AnN. § 682.20 (West 2003); Kan. Stat. AnN. § 5-418 (2001); Ky. Rev. Stat. AnN. § 417.220 (West 2006); Me. Rev. Stat. AnN. tit. 14, § 5945 (2003); Mass. Gen. Laws AnN. ch. 251, § 18 (West 2004); Mo. ANN. STAT. $\$ 435.440$ (West 2010); OHIO REV. CODE ANN. § 2711.02 (West 2006).

351. See, e.g., Tex. Civ. Prac. \& Rem. Code ANn. § 171.098(a)(1) (West 2011).

352. See, e.g., S. Cal. Edison Co. v. Peabody W. Coal Co., 977 P.2d 769, $773-74$ (Ariz. 1999) (noting that "[e]ach state is free to apply its own procedural requirements so long as those procedures do not defeat the purposes of the [FAA]"); Am. Gen. Fin. Servs. v. Vereen, 639 S.E.2d 598, 601 (Ga. Ct. App. 2006) (holding that an order denying a "motion to compel arbitration is not directly appealable under [Georgia] procedural law" and that "procedural law is not preempted by the FAA"); Simmons Co. v. Deutsche Fin. Servs. Corp., 532 S.E.2d 436, 437 (Ga. Ct. App. 2000) (holding that "the FAA does not preempt Georgia procedural law allowing the appeal" of an order compelling arbitration); Saavedra v. Dealmaker Devs., LLC, 8 So.3d 758, 762 (La. Ct. App. 2009) (" $[\mathrm{W}] \mathrm{e}$ find that the FAA does not preclude applying Louisiana procedural law regarding the right to appeal an interlocutory judgment denying arbitration."); Wells v. Chevy Chase Bank, F.S.B., 768 A.2d 620, 629 (Md. Ct. App. 2001) ("[W]e hold that the Maryland procedural rule, recognizing an order compelling arbitration to be a final and appealable judgment, is not preempted by the FAA."); Weston Secs. Corp. v. Aykanian, 703 N.E.2d 1185, 1189 (Mass. App. Ct. 1998) (holding that the "Massachusetts procedural rule depriving [parties] of an immediate appeal from the judge's order compelling [arbitration]" does not "undermine[] the Federal goal of enforcing agreements to arbitrate in State and Federal courts"); McClellan v. Barrath Constr. Co. Inc., 725 S.W.2d 656, 658 (Mo. Ct. App. 1987) (holding that the FAA would not preempt a Missouri law allowing an appeal of an order compelling arbitration, "provided [Missouri Law] do[es] nothing to thwart the substantive rights granted in the federal act"); Scottish Re Life Corp. v. Transamerica Occidental Life Ins. Co., 647 S.E.2d 102, 107 (N.C. Ct. App. 2007) (Geer, J., concurring) ("[T] he FAA does not preempt state law governing appeals relating to arbitrations."); In re D. Wilson Const. Co., 196 S.W.3d 774, 780 (Tex. 1996) (holding that "the FAA does not preempt" the Texas law allowing for interlocutory appeals of orders issued under the FAA).

353. See, e.g., Superpumper, Inc. v. Nerland Oil, Inc., 582 N.W.2d 647, 651 (N.D. 1998) (considering "the procedural requirements of the FAA in deciding whether an order compelling arbitration is appealable under [North Dakota law]"); Berger Farms v. First Interstate Bank of Or., 939 P.2d 64, 69 (Or. Ct. App. 1997) (holding that the FAA preempted the statute at issue because the FAA "expressly provides for immediate appeals from trial court orders denying motions to stay litigation pending arbitration," but "Oregon procedural law prohibits such appeals"), rev'd, 995 P.2d 1159 (Or. 2000), overruled, Bush v. Paragon Prop., Inc., 997 P.2d 882, 887 (Or. Ct. App. 2000) (finding that "[w]hether or not Congress intended to require state courts to provide interlocutory appellate review of orders denying arbitration when state law does not permit them to conduct that review, it is constitutionally prohibited from imposing that requirement"); Dakota Wesleyan Univ. v. HPG Int'l, Inc., 560 N.W.2d 921, 922 (S.D. 1997) ("[W]e turn to the FAA for guidance in determining whether the circuit court's order to compel arbitration is appealable."). 
arbitration, and of those compelling arbitration, is grounded in the "national policy favoring arbitration," and the fact that a "prime objective" of arbitration is to achieve "expeditious results." "354 Therefore, while an immediate appeal of a decision denying a motion to compel arbitration is necessary to ensure the benefits of arbitration are not lost in their assertion, ${ }^{355}$ an appeal of a decision compelling arbitration "creates yet another layer of review, which again delays all other proceedings" and "runs contrary to the principles of efficiency in . . the FAA . . . ."356

After Concepcion, state laws that impose procedural requirements that are inconsistent with the FAA — whether for appeals of orders denying or compelling arbitration-appear suspect. To appeal an order denying arbitration, some states provide only a discretionary appeal, ${ }^{357}$ whereas the FAA provides an appeal of right. ${ }^{358}$ The FAA may preempt the state rule in this situation. Impeding secondary review of a denial of arbitration delays arbitration in many circumstances where the parties' intent is clear, and can defeat the benefits of arbitration entirely.

As discussed above, state procedural law is not automatically immune from preemption, and it is probably irrelevant that the timing of appeals is often considered procedural. Indeed, the Concepcion majority never mentioned, let alone relied on, the substance-procedure distinction. Rather, the Court employed a traditional obstacle preemption analysis. ${ }^{359}$

More importantly, in reasoning why the Discover Bank rule erected an obstacle to the FAA's objectives, the Court in Concepcion heavily relied on the costs of appealing a class certification decision. The Court noted that "[a]rbitration is poorly suited to the higher stakes of class litigation," where "a defendant may appeal a certification decision on an interlocutory basis and, if unsuccessful, may appeal from a final judgment as well." "360 By contrast, the Court stated that " "[i]n bilateral arbitration, parties forgo the procedural rigor and appellate review of the courts in order to realize the benefits of private dispute resolution: lower costs, greater efficiency and speed, and the ability to choose expert adjudicators

354. AT\&T Mobility LLC v. Concepcion, 131 S. Ct. 1740, 1749 (2011) (citations omitted).

355. See Blinco v. Green Tree Servicing, LLC, 366 F.3d 1249, 1251 (11th Cir. 2004) (noting that "Congress acknowledged that one of the principal benefits of arbitration" is "swift access to appellate review").

356. Polina Kushelev, Note, An International Approach to Breaking the Core of the Bankruptcy Code and FAA Conflict, 28 EMORY BANKR. DEV. J. 355, 368 (2012).

357. See, e.g., Saavedra, 8 So.3d at 762.

358. 9 U.S.C. $\$ 16(\mathrm{a})(1)(\mathrm{B})(2006)$.

359. Concepcion, $131 \mathrm{~S}$. Ct. at 1753.

360. Id. at 1752 
to resolve specialized disputes.",361 Accordingly, the Court found that class actions were poorly suited to the arbitration context, in part because of a defendant's ability to appeal at both the interlocutory and final judgment stages, thereby increasing the procedural difficulty and financial feasibility of the litigation. ${ }^{362}$

The above passage in Concepcion is potentially devastating for state rules on appeals from arbitration orders, where such rules are not consistent with the FAA. The Court essentially suggested that interlocutory appeals delaying arbitration, in and of themselves, may run afoul of the policies underpinning the FAA. If class actions contravene the goals of arbitration because they bog the parties down in time-sucking interlocutory appeals, then state rules permitting appeals of orders compelling arbitration necessarily would violate the same policies.

For that reason, the Georgia Supreme Court's post-Concepcion decision in American General Financial Services v. Jape, ${ }^{363}$ rests on shaky footing. That case concerned Georgia laws that only permitted appeals from orders denying arbitration if they complied with state interlocutory appeal procedures. ${ }^{364}$ Those laws, the court held, were procedural rules that were not preempted by the FAA because they determined " only the efficient order of proceedings" and therefore did "not affect the enforceability of the . . . agreement itself." "365 But Jape ignores Concepcion's strong suggestion that the "efficient order of proceedings" "366 was relevant in deciding questions of preemption. Indeed, several judges who concurred in that decision on other grounds recognized "there is considerably more tension than the majority opinion admits between Georgia's interlocutory appeal statute... and the FAA's direct appeal provision . ....367 Therefore, while we are aware of no post-Concepcion holding that the FAA preempts state rules governing appeals of arbitration orders, ${ }^{368}$ it is well recognized that Concepcion has fundamentally

\footnotetext{
361. Id. at 1751 (quoting Stolt-Nielsen S.A. v. Animalfeeds Int'l Corp., 559 U.S. 662, 685 (2010)).

362. Id. at 1752 ("In litigation, a defendant may appeal a certification decision on an interlocutory basis and, if unsuccessful, may appeal from a final judgment as well.”).

363. 732 S.E.2d 746 (Ga. 2012).

364. See id. at 747.

365. Id. at 750 (quoting Doctor's Assocs., Inc. v. Casarotto, 517 U.S. 681, 688 (1996)).

366. See Concepcion, $131 \mathrm{~S}$. Ct. at 1749.

367. Jape, 732 S.E.2d at 751 (Nahmias, J., concurring specially).

368. See, e.g., Id. at 750 (majority opinion); Cnty. of Haw. v. Unidev, LLC, No. CAAP-110000019, 2011 WL 4998491 (Haw. Ct. App. Oct. 17, 2011) (holding post-Concepcion that "an order compelling arbitration is an appealable collateral order under Hawai'i state law"); Wis. Auto Title Loans v. Jones, No. 2011AP2482, 2013 WL 425449 (Wis. Ct. App. Feb. 5, 2013) (certifying to the Wisconsin Supreme Court the question of whether "an order denying a motion to compel arbitration
} 
changed the calculus of this issue.

\section{Discovery}

To illustrate the concept of FAA obstacle preemption, the Concepcion majority opined that a state rule requiring "judicially monitored discovery" would be self-evidently preempted under the FAA. ${ }^{369}$ That is because, "[i]n practice," such a rule "would have a disproportionate impact on arbitration agreements" even if "it would presumably apply to contracts purporting to restrict discovery in litigation as well." ${ }^{370}$ Even the dissent apparently agreed that the FAA preempted such a rule. ${ }^{371}$

Although the Supreme Court spoke of "judicially monitored discovery, ${ }^{, 372}$ the judicially monitored modifier is not necessary for the discovery example to pose preemption problems. After all, any discovery baselines imposed by state statute or common law rule, whether monitored by court or arbitrator, would disproportionately affect arbitration, because discovery in federal and state court is a process already governed by federal and state rules of civil procedure, respectively. Moreover, limited discovery indisputably furthers the aims of efficiency, informality, and lower costs. Therefore, it appears that all discovery limitations are vulnerable-including Armendariz's requirement of "adequate discovery" ${ }^{\prime 37}$ — under the reasoning offered by the Concepcion majority, as suggested in a number of post-Concepcion cases. ${ }^{374}$ Those cases, however, upheld either institutional arbitration rules or ad hoc rules that permitted limited discovery.

The only remaining question then is whether a defendant may cate-

[is] immediately appealable as a 'final' order under [Wisconsin law] or the Federal Arbitration Act").

369. Concepcion, 131 S. Ct. at 1747.

370. Id.

371. See id. at 1758 (Breyer, J., dissenting) (arguing that "class arbitration is consistent with the use of arbitration," in contrast to "the majority's examples," including "judicially monitored discovery").

372. Id. at 1747 (majority opinion) (emphasis added).

373. Armendariz v. Found. Health Psychcare Servs., Inc., 6 P.3d 669, 683 (Cal. 2000).

374. See, e.g., Lucas v. Hertz Corp., No. C 11-01581 LB, 2012 WL 5199384, at *2 (N.D. Cal. Oct. 22, 2012) ("Concepcion ... suggests that limitations on arbitral discovery no longer support a finding of substantive unconscionability.”); Simmons v. Morgan Stanley Smith Barney, LLC, 872 F. Supp. 2d 1002, 1015-16 (S.D. Cal. 2012) (FINRA discovery rule applied); Valle v. Lowe's HIW, Inc., No. 11-1489 SC, 2011 WL 3667441, at *8 (N.D. Cal. Aug. 22, 2011) (AAA discovery rule applied); Pilitz v. Bluegreen Corp., No. 6:11-cv-388-Orl-19KRS, 2011 WL 3359641, at *5 (M.D. Fla. Aug. 4, 2011) (applying rules that limit the discovery period to sixty days and allow only three depositions, twenty interrogatories, and fifteen requests for documents per side); Hopkins v. World Acceptance Corp., 798 F. Supp. 2d 1339, 1349-50 (N.D. Ga. 2011) (AAA). 
gorically insulate itself by barring all discovery in the arbitration agreement in the name of efficiency and arbitration autonomy. At least one court has indicated that such blanket prohibitions are permissible. ${ }^{375}$ But another court has held that the same arbitration agreement was substantively unconscionable, because one party would have been required to "articulate its arguments with a clarity bordering on prescience, for it has no right to discovery and will have no opportunity to rebut the [other] party's response ...., 376

The Tierra court, which upheld a categorical ban on discovery, may have over-read existing FAA preemption jurisprudence. There is a key difference between limiting discovery and eliminating it, and the benefits of limiting discovery do not necessarily lead to the conclusion that eliminating discovery altogether also serves the aims of arbitration. And Concepcion might be read to permit some discovery. Although institutional arbitration rules impose limits on discovery, we are not aware of any that categorically ban discovery. In light of Concepcion's reliance on institutional rules to divine the "fundamental nature" of arbitration, agreements that prohibit discovery altogether may themselves be considered inconsistent with the nature of arbitration.

\section{Confidentiality}

State decisions, which have invalidated confidentiality provisions in arbitration clauses as unconscionable, are also suddenly vulnerable in light of Concepcion. The Court described confidentiality as a featurenot a bug — of the arbitration process. ${ }^{377}$ Indeed, class-wide procedures are purportedly incompatible with arbitration "as a structural matter," in part, because "[c]onfidentiality becomes more difficult.",378 One might conclude from this passage that the Court deemed confidentiality as an essential feature of arbitration. Elsewhere, however, the Court appears to use more modest language, touting confidentiality as a benefit that parties could choose for themselves. ${ }^{379}$

375. See Tierra Right of Way Servs., Ltd. v. Abengoa Solar Inc., No. CV-11-00323-PHXGMS, 2011 WL 2292007, at *5 (D. Ariz. June 9, 2011) (enforcing prohibition on discovery or document production).

376. Unimax Express, Inc. v. Cosco N. Am., Inc., No. CV 11-02947 DDP (PLAx), 2011 WL 5909881, at *4 (C.D. Cal. Nov. 28, 2011).

377. Concepcion, 131 S. Ct. at 1749-50.

378. Id. at 1750 .

379. See id. at 1749 ("The point of affording parties discretion in designing arbitration processes is to allow for efficient, streamlined procedures tailored to the type of dispute. It can be specified, 
Assume that a contract includes an arbitration clause, which requires that "neither party may disclose the existence, content, or results of any arbitration or award." If the contract is one of adhesion between a large corporate entity and its customers, the Ninth Circuit and several other jurisdictions have held that such a confidentiality provision necessarily results in unfairness to the customer, even though it is facially neutral. ${ }^{380}$

This argument, where it has found traction, is based on the following rationale: a company will tend to be a repeat player in arbitration arising out of disputes under the contract - for example, with its customerswhereas each customer will likely only be a one-time participant in arbitration, if he or she becomes a participant at all. As a repeat player, the company will be able to "accumulate a wealth of knowledge about arbitrators, legal issues, and tactics,"381 including which arguments were held to be meritorious before certain arbitrators. While the Ninth Circuit in Ting originally found that the advantages of AT\&T's repeat player-status were "particularly harmful" where its contract affected seven million Californians, ${ }^{382}$ subsequently, that court also held that a company could garner such an unfair advantage even where the company contracted with hundreds or thousands of potential claimants. ${ }^{383}$

The concern over confidentiality provisions in arbitrations, however, is not uniformly shared. The Third Circuit challenged the premise that any individual plaintiff has been treated unfairly as a result of such a confidentiality provision. ${ }^{384}$ That court concluded that confidentiality provisions in arbitration agreements could not result in unfairness between the contracting parties, but instead could only make it more difficult for potential plaintiffs in future cases to be successful in arbitration. ${ }^{385}$ Accordingly, because the unconscionability doctrine "seeks to

for example, that the decisionmaker be a specialist in the relevant field, or that proceedings be kept confidential to protect trade secrets.").

380. See, e.g., Ting v. AT\&T, 319 F.3d 1126, 1151 (9th Cir. 2003); see also Pokorny v. Quixtar, Inc., 601 F.3d 987, 1002 (9th Cir. 2010) (characterizing a confidentiality provision as one that "unfairly favors Quixtar because it prevents Plaintiffs from discussing their claims with other potential plaintiffs and from discovering relevant precedent to support their claims").

381. McKee v. AT\&T Corp., 191 P.3d 845, 858 (Wash. 2008) (en banc) (internal grammatical marks omitted).

382. Ting, 319 F.3d at $1151-52$.

383. See Davis v. O'Melveny \& Myers, 485 F.3d 1066, 1078 (9th Cir. 2007) (noting that "Ting's concern was not limited strictly to potential claims by millions of "repeat players" because "[the employer] ha[d] placed itself in a far superior legal posture ... while, at the same time, [the employer] accumulate[d] a wealth of knowledge on how to negotiate the terms of its own unilaterally crafted contract").

384. See, e.g., Parilla v. IAP Worldwide Servs., Inc., 368 F.3d 269, 280 (3d Cir. 2004).

385. Id. 
prevent substantial unfairness between contracting parties having grossly unequal bargaining power," the court held that confidentiality provisions that impose the same rights and restraints on each of the contracting parties are enforceable. ${ }^{386}$ Some state courts have agreed that, so long as the confidentiality provision itself is "even-handed," a confidentiality provision in an arbitration agreement does not weigh in favor of finding the agreement unconscionable. ${ }^{387}$ And still other courts, such as the D.C. Circuit, have acknowledged the potential for unfairness due to a company's repeat player status, but found that it would be offset because arbitrations are also subject to scrutiny from lawyers and arbitration agencies like the AAA. ${ }^{388}$

One case in particular epitomizes the vulnerability of the state laws that hold that confidentiality provisions in arbitration agreements are unconscionable after Concepcion. The Supreme Court of Kentucky in Schnuerle v. Insight Communications Company considered whether a class action ban, a class arbitration ban, and a confidentiality provision, all contained in an arbitration agreement, were enforceable. ${ }^{389}$ The court first concluded, relying on Concepcion, that the class action and class arbitration ban contained in the arbitration agreement were not unconscionable, and must be given effect. ${ }^{390}$ Next, the court considered whether "Concepcion prevents state courts from disturbing confidentiality agreements included within arbitration agreements." 391 This court rejected this application of Concepcion. ${ }^{392}$

Although the Schnuerle court noted Concepcion's dicta that "[c]onfidentiality becomes more difficult" under class-wide arbitration, it was not convinced that the Court affirmatively indicated "that confidentiality agreements are likewise protected under [Concepcion's] holding." 393 Rather, relying on the Ninth Circuit's decision in Ting and other cases, the Schneurle court concluded that the arbitration agreement's confidentiality provision was unconscionable, "although facially neutral," because it "in effect" favored the defendant corporation. ${ }^{394}$

In our view, the Kentucky court's decision does not fully appreciate

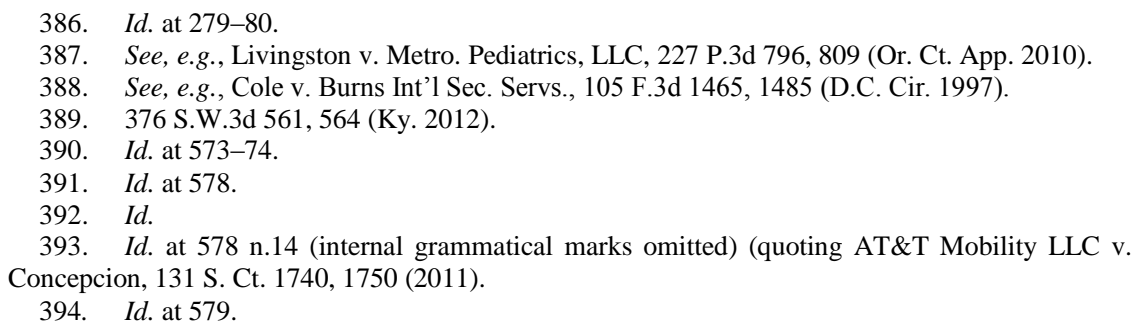


Concepcion's preemption analysis. It is well recognized that confidentiality is a principal advantage of arbitration. ${ }^{395}$ Invalidating confidentiality provisions through state unconscionability law effectively rewrites terms that contracting parties have agreed to and undermines the benefit of the bargain they have struck.

Similarly, procedural informality of arbitration is widely viewed as a principal advantage of arbitration, ${ }^{396}$ and the Court in Concepcion agreed. ${ }^{397}$ However, by holding that class action waivers were unconscionable, the Discover Bank rule invalidated terms in which the customer had agreed not to join his claims with those of others. ${ }^{398}$ Class arbitrations clearly do require a greater degree of procedural formality and also are less efficient in resolving disputes than a bilateral arbitration. The Supreme Court held that the Discover Bank rule thus interfered with arbitration by causing it to "sacrifice[] the principal advantage of arbitration - its informality - and make[] the process slower, more costly, and more likely to generate procedural morass than final judgment." 399

The Court could just as easily have held that state laws barring confidentiality agreements interfere with one of the principal advantages of arbitration, and that such laws unfairly target arbitration. It is no secret that the Court considered confidentiality to be one of the principal advantages of arbitration, alongside the parties' discretion to design their own efficient and streamlined procedures. ${ }^{400}$ In Concepcion, the Court stated approvingly, albeit in dicta, that in an arbitration agreement, "[i]t can be specified ... that the decisionmaker be a specialist in the relevant field, or that the proceedings be kept confidential to protect trade se-

395. See, e.g., Shelley McGill, Consumer Arbitration Clause Enforcement: A Balanced Legislative Response, 47 AM. BUS. L.J. 361, 364 (2010) (noting that "[r]ecognized benefits of arbitration include confidentiality, speed, and party autonomy"); Christopher R. Drahozal, Business Courts and the Future of Arbitration, 10 CARDOZO J. CONFLICT RESOL. 491, 507 (2009) (“[A]rbitration retains some of its advantages over litigation (such as choice of decision maker and confidentiality)."); S.I. Strong, Enforcing Class Arbitration in the International Sphere: Due Process and Public Policy Concerns, 30 U. PA. J. INT'L L. 1, 45 (2008) (writing that confidentiality "is one of the longenunciated benefits of arbitration").

396. See, e.g., Maureen A. Weston, Checks on Participant Conduct in Compulsory ADR: Reconciling the Tension in the Need for Good-Faith Participation, Autonomy, and Confidentiality, 76 IND. L.J. 591, 597 (2001) (writing that "[c]laimed benefits of arbitration are that it offers a more informal, less expensive, and efficient forum for resolving disputes"); Bruce L. Benson, An Exploration of the Impact of Modern Arbitration Statutes on the Development of Arbitration in the United States, 11 J.L. ECON. \& ORG. 479, 482 (1995) (noting that "the benefits of arbitration are widely recognized to include ... fast, informal, and inexpensive dispute resolution").

397. AT\&T Mobility LLC v. Concepcion, 131 S. Ct. 1740, 1748-49 (2011).

398. Id. at 1746 .

399. Id. at $1750-51$.

400. Id. at 1749 
crets." ${ }^{401}$ Moreover, given the presumption that court proceedings are open to the public, rules barring such confidentiality agreements will disproportionately affect arbitration. It therefore appears that the continued applicability of state rules finding confidentiality provisions unconscionable-such as those in Ting and Schnuerle-is suspect after Concepcion. $^{402}$

\section{Cost Splitting}

Courts frequently address the unconscionability of cost-splitting provisions, which may shift prohibitive costs onto the more vulnerable party. While in the past courts were given a wide berth to find arbitration agreements unenforceable on such grounds, Concepcion appears to marshal in a new era which would place significantly greater restraints on courts' ability to consider allegedly prohibitive arbitration costs unconscionable.

Courts frequently rely on Randolph in determining whether an arbitration agreement is unenforceable for imposing prohibitive arbitration costs or including other suspect cost-shifting provisions. ${ }^{403}$ In Randolph, the consumer argued that "the arbitration agreement's silence with respect to costs and fees creates a 'risk' that she will be required to bear prohibitive arbitration costs if she pursues her claims in an arbitral forum, and thereby forces her to forego any claims she may have against [the company]. ${ }^{\circ 04}$ The Court was not sympathetic to her argument because she had not met her burden of showing that the arbitration agreement should be invalidated due to prohibitive arbitration costs. ${ }^{405}$ However, the Court also wrote that "[i]t may well be that the existence of large arbitration costs could preclude a litigant ... from effectively vindicating her federal statutory rights in the arbitral forum."

The Court's concern about the potentially excessive costs of arbitration may appear at odds with the congressionally-declared "national policy favoring arbitration, ${ }^{, 407}$ a point not lost on commentators. After all,

\footnotetext{
401. Id. (emphasis added).

402. But see Kanbar v. O’Melveny \& Myers, 849 F. Supp. 2d 902, 909 (N.D. Cal. 2011) (finding that confidentiality provisions in "arbitration agreements are still subject to unconscionablility analysis," even following Concepcion and thus implying that they can still be unconscionable).

403. See Green Tree Fin. Corp. v. Randolph, 531 U.S. 79, 89-92 (2000).

404. Id. at 90 .

405. Id. at $91-92$.

406. Id. at 90

407. Southland Corp. v. Keating, 465 U.S. 1, 10 (1984).
} 
the Court has recognized that arbitration is a private means of dispute resolution. $^{408}$ And, the funding required to resolve disputes with a private third-party neutral, instead of a judge, will almost invariably come from the parties themselves. ${ }^{409}$ While litigants are not responsible for the expenses of the judge, they are generally responsible for covering court costs (i.e., attorney fees, filing fees, transcript costs, etc.), ${ }^{410}$ and the high costs of litigation often discourage aggrieved parties from seeking to vindicate their rights.

To the extent that a court is protective of a party's ability to pursue his claims in arbitration without financial hardship, even though a similarly-situated individual would not receive such protections in litigation, the court risks discriminating against arbitration in a manner contrary to the purposes underlying the FAA. According to one commentator, "the costs rationale for finding unconscionability may be based upon on false premises. In any event, this rationale fails to distinguish arbitration from litigation while preferring litigation as a standard for judging arbitration agreements. Consequently, it is incompatible with the policy favoring arbitration." ${ }^{411}$

After Randolph, courts "generally adopted a case-by-case determination" of whether an arbitration agreement imposes excessive costs, considering factors such as "the claimant's ability to pay, the difference between costs of litigation and arbitration, and the likelihood that the cost of arbitration will deter the bringing of claims." ${ }^{412}$ Two general approaches developed. The Fourth Circuit, which was the first circuit to consider the issue of prohibitive arbitration costs after Randolph, undertook "a costs comparison between arbitration and litigation as a whole, ${ }^{, 413}$ which could be analyzed with reference to these factors. ${ }^{414}$ However, the Sixth Circuit considered that the issue should not be so focused on the individual claimant, but upon whether the difference in the

\footnotetext{
408. See AT\&T Mobility LLC v. Concepcion, 131 S. Ct. 1740, 1748 (2011) ("The 'principal purpose' of the FAA is to 'ensur[e] that private arbitration agreements are enforced according to their terms." (emphasis added) (internal citations omitted)).

409. See, e.g., Burton, supra note 295, at 493 (noting that the costs of dispute resolution "generally are cheaper in arbitration [than litigation] though the parties must pay filing fees and the arbitrator's fee"); see also id. at 494 (writing that "the costs of litigation discourage plaintiffs, too").

410. E.g., Fleischmann Distilling Corp. v. Maier Brewing Co., 386 U.S. 714, 717-18 (1967) (recognizing the American rule that each side bears their costs in litigation).

411. Burton, supra note 295, at 493.

412. Randall, supra note 295 , at 200.

413. Dan O'Hearn, Beyond "Let Them Eat Cake": An Argument for the Armendariz Method of Cost Allocation in Mandatory Employment and Consumer Arbitration, 2007 J. DISP. RESOL. 541, 549 (2007).

414. Bradford v. Rockwell Semiconductor Sys., Inc., 238 F.3d 549, 556 (4th Cir. 2001).
} 
cost of arbitration and litigation was so substantial as to deter the bringing of comparable claims. ${ }^{415}$ With this end in mind, the Sixth Circuit also considered "the likelihood that similarly situated plaintiffs would be deterred from bringing a claim due to prohibitive costs." fore have not developed a consistent approach to considering whether the costs of arbitration are excessive.

In the aftermath of Concepcion, judicial attempts to strike down arbitration agreements on the basis of allegedly excessive arbitration costs will likely be reined in. Concepcion emphasized that a state law rule that in theory is based on "the general principle of unconscionability or public-policy disapproval of exculpatory agreements" cannot "have a disproportionate impact on arbitration agreements."417 The manner in which several courts have reasoned that allegedly excessive arbitration costs are unconscionable appears to do just that.

A brief discussion of two decisions illuminates the potential ways in which courts could consider arbitration costs. First, based on a California state law rule, the Ninth Circuit held that an arbitration clause was unconscionable where (a) the employee was responsible for paying the $\$ 125$ initial filing fee; (b) the employer was responsible for paying the first day of hearing costs; and (c) the parties otherwise shared all arbitration costs. ${ }^{418}$ In that case, the Ninth Circuit stated in dicta that "the only valid fee provision is one in which an employee is not required to bear any expense beyond what would be required to bring the action in court." 419 This statement may appear to be facially neutral, in that it requires the costs to the claimant to be equal, whether the claim is pursued in arbitration or litigation.

That being so, this rule is not on firm footing following Concepcion. First and foremost, state courts likely cannot use Randolph offensively to strike down arbitration clauses under state law. ${ }^{420}$ Moreover, such a rule could never be generally applicable. The fact that the parties have agreed to arbitration presupposes that the costs of the arbitrator must be borne, in some division, by the parties. California therefore has adopted a per se rule that an arbitration agreement will only pass the unconscionability test where the costs to the claimant are not greater than would be

415. Morrison v. Circuit City Stores, Inc., 317 F.3d 646, 658 (6th Cir. 2003) (citing Bradford, 238 F.3d at 556).

416. O'Hearn, supra note 413, at 550 (citing Morrison, 317 F.3d at 663-65) (emphasis added).

417. AT\&T Mobility LLC v. Concepcion, 131 S. Ct., 1740, 1747 (2011).

418. Ferguson v. Countrywide Credit Indus., Inc., 298 F.3d 778, 781-82 (9th Cir. 2002).

419. Id. at 786 .

420. See supra notes 314-27 and accompanying text. 
incurred in litigation, even though, by virtue of the fact that the parties agreed to arbitration, additional costs (i.e., those of the arbitrator) must be incurred. ${ }^{421}$ Thus, an arbitration agreement would be unconscionable if the claimant would be required to shoulder some portion of these additional, necessarily incurred costs.

The California rule specifically conditions the enforceability of an arbitration agreement on whether one party to that agreement (i.e., the employer) agrees to certain costs that would only be incurred in arbitration. Although this state law contract defense is an application of unconscionability that is facially neutral by requiring the costs of arbitration and litigation to the claimant to be equal, such a rule would have a disproportionate impact upon arbitration agreements. Therefore, the FAA likely preempts this California unconscionability rule, as well as similar state law rules. ${ }^{422}$

Another approach to determining whether an arbitration agreement is not enforceable on the basis of excessive arbitration costs was articulated by the Alaska Supreme Court in Gibson. ${ }^{423}$ In that case, an employee argued that an arbitration agreement was unconscionable because he was expected to be apportioned fifty percent of the arbitration costs for his claim under the Alaska Wage and Hour Act (AWHA). ${ }^{424}$ While the arbitration agreement itself was silent on the issue of costs, the court took notice of the parties' expectation of a "fifty/fifty split," and the fact that arbitration costs in such a case could easily exceed $\$ 6,000 .{ }^{425}$

The court found that a "wage and hour" claimant, such as the employee in Gibson, who was seeking unpaid overtime compensation for work performed over the course of several years, would only be required to pay $\$ 150$ in "forum costs" to have his or her claim adjudicated in court. ${ }^{426}$ This figure stood in stark contrast to the "uncertain but much greater forum costs for which Gibson would be liable in arbitration." 427 Because the AWHA contained provisions "designed to deter employers from violating the act and to encourage employees to take action to rem-

421. Armendariz v. Found. Health Psychcare Servs, Inc., 6 P.3d 669, 687. See also supra notes 416-17 and accompanying text.

422. See also Randall, supra note 295, at 209 (arguing that the California state-law rule that employers must be required to pay all costs unique to arbitration, is a "per se approach ... [that] conflicts with the basic purpose of the Federal Arbitration Act, to place arbitration agreements on the same footing as other contracts" (internal quotation marks omitted)).

423. Gibson v. Nye Frontier Ford, Inc., 205 P.3d 1091 (Alaska 2009).

424. Id. at 1099

425. Id.

426. Id. at 1099

427. Id. 
edy violations," the Gibson court held that "[i]mposing substantial forum costs would run counter to" that purpose. ${ }^{428}$

The inquiry in Gibson, much like the California rule, considers the comparative costs of filing the claim in arbitration and litigation. Both tests find the arbitration agreements at issue to be unconscionable based on potentially excessive costs to the claimant, and both tests use a comparative costs approach to reach that conclusion. The difference is that Gibson also considered the potential total costs to the claimant, the type of claim, and the potential recovery. ${ }^{429}$ By addressing the issue of excessive costs by looking at the totality of circumstances (including the claimant's ability to pay) rather than dictating at the outset the division of costs for parties who agreed to resolve their disputes in arbitration, the totality-of-the-circumstances approach appears to be a sounder basis upon which courts can determine whether the costs of arbitration are excessive, under the Court's reasoning in Randolph. However, courts could also find this approach to be preempted by the FAA as well. After all, Concepcion, as interpreted in American Express, unequivocally held that the FAA's "command to enforce arbitration agreements trumps any interest in ensuring the prosecution of low-value claims." ${ }^{\text {"30 }}$ That admonition is equally relevant to the argument that a party is prevented from vindicating his or her rights as a result of high arbitration costs, as in Randolph, and based on the high cost of obtaining an expert witness, as in American Express.

\section{Forum Selection Clauses}

Another well-trod question is whether forum selection clauses are unenforceable under state law and if so, whether the FAA preempts the state rule. The Supreme Court has long held that forum selection clauses are generally enforceable under federal common law unless, among other things, "enforcement would contravene a strong public policy of the forum in which suit is brought, whether declared by statute or by judicial decision."

\footnotetext{
428. Id.

429. Id. at $1098-99$

430. Am. Express Co. v. Italian Colors Rest., 133 S. Ct. 2401, 2312 n.5 (2010) (citing AT\&T Mobility v. Concepcion, 131 S. Ct. 1740, 1752-53 (2011)).

431. M/S Bremen v. Zapata Off-Shore Co., 407 U.S. 1, 15 (1972), superseded by statute, 28 U.S.C.A. \$ 1404 (West 2013), as recognized in Outokumpu Eng'g Enters., Inc. v. Kvaerner EnviroPower, Inc., 685 A.2d 724, 734 n.6 (Del. Super. Ct. 1996); see also Carnival Cruise Lines, Inc. v. Shute, 499 U.S. 585, 596 (1991).
} 
cion argued that preemption of the Discover Bank rule would topple the Court's well-settled jurisprudence regarding forum selection clauses. ${ }^{432}$ This argument is an overstatement. As it stands, the majority of cases addressing the issue have held that the FAA preempts state laws restricting forum selection clauses in arbitration agreements. Concepcion does not alter, but in fact, reinforces, the majority rule.

Generally speaking, there are two primary ways to invalidate a forum selection clause: state franchise statutes and common law unconscionability. Several decisions predating Concepcion invalidated arbitration agreements for including clauses that required arbitration in distant jurisdictions. ${ }^{433}$ State franchise statutes, many of which are modeled after the Uniform Securities Act, sometimes include anti-waiver provisions that bar forum selection clauses. For example, California, ${ }^{434}$ Rhode Island, ${ }^{435}$ Montana ${ }^{436}$ and South Carolina, ${ }^{437}$ have general statutes making all forum selection clauses against the state's public policy. ${ }^{438}$ State courts interpreting these statutes often have invalidated forum selection clauses.

Consider South Carolina's statute, which shows the attention that arbitration agreements receive under these statutes. The South Carolina statute generally prohibits forum selection clauses in one section, and specifically addresses arbitration forum-selection clauses in another. Courts have held that the FAA preempts the first but not the second. ${ }^{439}$

432. See Brief for Respondents at 28, AT\&T Mobility LLC v. Concepcion, 131 S.Ct. 1740, No. 09-893 (2011), 2010 WL 4411292 ("The principle that "[f]orum selection clauses contained in form ... contracts are subject to judicial scrutiny for fundamental fairness' and may be 'condemn[ed] ... as against public policy,' applies equally to arbitration clauses." (quoting Carnival Cruise Lines, 499 U.S. at 595) (citing Vimar Seguros y Reaseguros, S.A. v. M/V Sky Reefer, 515 U.S. 528, $539(1995)))$.

433. See, e.g., Nagrampa v. MailCoups, Inc., 469 F.3d 1257, 1287-92 (9th Cir. 2006) (en banc).

434. CAL. Bus. \& PROF. Code $\S 20040.5$ (West 1994), preempted by Bradley v. Harris Research, Inc., 275 F.3d 884, 886 (9th Cir. 2001) (holding that the FAA preempted $\S 20040.5$ ).

435. R.I. GEN. LAWS ANN. § 19-28.1-14 (West 2013).

436. Mont. Code ANN. § 28-2-708 (West 2009), preempted by Chambers v. Montana Contractors Ass'n Health Care Trust, 797 F. Supp. 2d 1050, 1057 (D. Mont. 2009) (holding that ERISA preempted § 28-2-708).

437. S.C. CODE ANN. § 15-7-120 (1990), preempted by Tritech Elec., Inc. v. Frank M. Hall \& Co., 540 S.E.2d 864, 866 (S.C. Ct. App. 2000) (holding that the FAA preempted § 15-7-120).

438. See, e.g., Spinks v. Krystal Co., No. 6:07-2619-HMH, 2007 WL 2822788, at *3 (D. S.C. Sept. 26, 2007) (stating that $\$ 15-7-120$ provided "evidence of a strong public policy in South Carolina of non-enforcement of a forum selection clause that would deprive a South Carolina litigant of his choice of forum"); Montana ex rel. Polaris Indus., Inc. v. Dist. Court of the Thirteenth Judicial Dist., 695 P.2d 471, 473 (Mont. 1985) (Sheehy, J., specially concurring) (noting that $§ 28-2-708$ "states a public policy ... [that] makes forum-selection clauses in contracts in our state void").

439. Consol. Insured Benefits, Inc. v. Conseco Med. Ins., Co., 370 F. Supp. 2d 397, 402 (D. S.C. 2004); see also Tritech Elec., Inc. v. Frank M. Hall \& Co., 540 S.E.2d 864, 866 (S.C. Ct. App. 
Although the South Carolina statute itself is silent on the issue, courts have ruled that forum selection clauses violating the statute also offend public policy. ${ }^{40}$

In addition to state franchise statutes, the common law of unconscionability provides another avenue to invalidate forum selection clauses. The majority of courts have held that such decisions are preempted by the FAA. ${ }^{441}$ Nonetheless, federal and state courts in California, ${ }^{442}$ Hawaii, ${ }^{443}$ Illinois, ${ }^{44}$ Ohio, ${ }^{45}$ Kentucky, ${ }^{446}$ Missouri, ${ }^{447}$ and Montana ${ }^{448}$ have ruled that forum selection clauses in arbitration agreements are unenforceable under the FAA because they are unconscionable.

Keystone is the leading example of the minority rule. At issue were two Montana statutes voiding ${ }^{449}$ out-of-state forum-selection clauses. ${ }^{450}$ The Montana Supreme Court reasoned that the statutes did "not conflict with the FAA" because they did not single out arbitration clauses. ${ }^{451}$ As they were written in arbitration-neutral terms, they applied to both arbi-

2000) (holding that FAA preempted South Carolina statute precluding enforcement of arbitration agreements that provided for arbitration proceedings outside of South Carolina).

440. Ins. Prods. Mktg., Inc. v. Indianapolis Life Ins. Co., 176 F. Supp. 2d 544, 550 (D. S.C. 2001).

441. See, e.g., Bradley v. Harris Research, Inc., 275 F.3d 884, 892 (9th Cir. 2001); Gill v. World Inspection Network Int'l, Inc., No. 06CV3187(JFB)(MLO), 2006 WL 2166821 (E.D.N.Y. July 31, 2006); Doctor's Assocs., Inc. v. Hamilton, 150 F.3d 157, 163-64 (2d Cir. 1998) (enforcing arbitral forum selection clause after concluding that unconscionability defense did not overcome presumptive enforceability under the FAA), cert. denied, 525 U.S. 1103 (1999); see also Mgmt. Recruiters Int'1 v. Bloor, 129 F.3d 851, 856 (6th Cir. 1997); Snyder v. Smith, 736 F.2d 409, 418 (7th Cir. 1984), overruled on other grounds by Felzen v. Andreas, 134 F.3d 873 (7th Cir. 1998).

442. See, e.g., Wilmot v. McNabb, 269 F. Supp. 2d 1203, 1209 (N.D. Cal. 2003); see also Comb v. PayPal, Inc., 218 F. Supp. 2d 1165, 1170 (N.D. Cal. 2002).

443. See, e.g., Domingo v. Ameriquest Mortg. Co., 70 F. App'x 919 n.1 (9th Cir. 2003).

444. See, e.g., Plattner v. Edge Solutions Inc., No. 03-CV-2646, 2004 WL 1575557, at*1 (N.D. Ill. Apr. 1, 2004).

445. See, e.g., Hagedorn v. Veritas Software Corp., 250 F. Supp. 2d 857, 862 (S.D. Ohio 2002); but see Lindsey v. Sinclair Broad. Grp., Inc., No. 19903, 2003 WL 22972357 (Ohio Ct. App. Dec. 19, 2003) (holding that a forum selection clause in an arbitration agreement was not unconscionable where plaintiff failed to demonstrate financial inability to travel to the designated forum).

446. See, e.g., Wilder v. Absorption Corp., 107 S.W.3d 181, 185 (Ky. 2003).

447. See, e.g., Swain v. Auto Servs., Inc., 128 S.W.3d 103, 108 (Mo. Ct. App. 2003) (holding that even though the FAA governs arbitration agreements, "[Missouri] courts will not enforce clauses selecting a forum outside Missouri that are unfair or unreasonable"); but see High Life Sales Co. v. Brown-Forman Corp., 823 S.W.2d 493, 497 (Mo. 1992) (joining "the better-reasoned majority rule" and enforcing forum selection clauses, "so long as doing so is neither unfair nor unreasonable").

448. See Keystone, Inc. v. Triad Sys. Corp., 971 P.2d 1240, 1245-46 (Mont. 1998).

449. MonT. CODE ANN. \$§ 28-2-708, 27-5-323 (2013).

450. Keystone, 971 P.2d at 1245-46.

451. Id. at 1245 . 
tration clauses and forum-selection clauses in contracts generally. ${ }^{452}$

Following Concepcion, some courts have continued to invalidate forum selection clauses requiring the plaintiff to arbitrate in far-flung jurisdictions. For instance, in Willis v. Nationwide Debt Settlement Group ${ }^{453}$ the court refused to enforce a forum-selection clause in an arbitration agreement on the following basis:

It is fair to conclude on this record that Plaintiffs are not capable of paying for and participating in arbitration in San Joaquin County, California, and, therefore, that enforcement of the forum-selection provision would effectively deny Plaintiffs of a meaningful day in court. In addition, the Court finds this forumselection provision was against the strong public policy in Oregon against enforcement of forum-selection provisions requiring consumers to assert claims relating to consumer contracts in another forum.

Cases like Willis and Keystone are likely not on firm footing after Concepcion because they do not acknowledge that forum selection clauses serve many pro-arbitration ends. Most notably, these clauses may drive down total costs and ensure the greatest expertise among those involved in the arbitration proceedings. It is well known that certain major cities are financial hubs and therefore centers of arbitration. Industryrelated expertise may be considered by the parties to be a requirement in many arbitrations; a forum selection clause can have the benefit of designating a forum home to arbitrators experienced in the relevant field. Indeed, the Court in Concepcion noted this advantage, stating that " $[t]$ he point of affording parties discretion in designing arbitration processes is to allow for efficient, streamlined procedures tailored to the type of dispute. It can be specified, for example, that the decisionmaker be a specialist in the relevant field...."455 It takes no great leap, for example, to presume that the parties in Keystone would have had many more arbitrators from which to choose in California, the forum specified by contract, than Montana, to resolve their breach of contract dispute.

Another benefit of forum selection clauses, as the Supreme Court recognized in Carnival Cruise Lines, is that they may allow the draftera repeat player - to focus its legal expertise to a single forum, thereby

452. See id. ("Montana law, therefore, does not distinguish between forum selection clauses which are part of contracts generally and forum selection clauses found in agreements to arbitrate. Such a distinction, if one existed, would certainly manifest the kind of unequal treatment that Casarotto prohibits. The lack of such a distinction is evidence that the statute does not conflict with the FAA.").

453. 878 F. Supp. 2d 1208 (D. Or. 2012).

454. Id. at 1221 (citing OR. REV. STAT. § 81.150(2) (2008)).

455. AT\&T Mobility LLC v. Concepcion, 131 S. Ct. 1740, 1749 (2011) (emphasis added). 
enabling it to offer better contractual terms overall. ${ }^{456}$ Delaware, for instance, has a highly-developed corporate law regime that offers a business-drafter more predictability, and thus allows it to economize on other costs, such as consumer services. This concern is especially heightened where the drafter has contracted with counterparties that reside in many different jurisdictions. Even the most salient cost of forum selection clauses - the cost and time of traveling to the distant and unfamiliar home court of the drafter-may have efficiency benefits. The forum selection clause may prescribe a far-flung forum "in order to avoid formal dispute resolution altogether, and the avoidance is valuable to the parties in some way." 457 Thus, by raising the costs of arbitration, the clause may in fact provide an incentive for pre-arbitration dispute resolution, thereby lowering costs overall.

\section{THE CONSEQUENCES OF CONCEPCION: FEDERAL LAW}

Following Concepcion, courts are suddenly faced with two seemingly conflicting bodies of law. The first is Concepcion and its progeny, which invalidate rules that conflict with "the fundamental attributes of arbitration," 458 even if such rules are necessary to ensure that small dollar claims are pursued. The second is Mitsubishi and Randolph, which have been broadly construed to establish a federal common law prohibiting arbitration where so doing would thwart the "vindication of federal statutory rights." 459 The Supreme Court's recent decision in American Express heavily tips the scales in favor of Concepcion, loosening another check on the ability of repeat institutional players to draft supposedly one-sided arbitration agreements. ${ }^{460}$

At first blush, one might think that Concepcion has little to say about conflicts among federal laws. After all, Concepcion was rooted in a conflict between the FAA and state law, and was decided on obstacle

\footnotetext{
456. See Carnival Cruise Lines, Inc. v. Shute, 499 U.S. 585, 594 (1991) (“[P]assengers who purchase tickets containing a forum clause like that at issue in this case benefit in the form of reduced fares reflecting the savings that the cruise line enjoys by limiting the fora in which it may be sued.").

457. Erin Ann O'Hara, The Jurisprudence and Politics of Forum-Selection Clauses, 3 CHI. J. INT'L L. 301, 311 (2002).

458. Concepcion, 131 S. Ct. at 1748.

459. See Mitsubishi Motors Corp. v. Soler Chrysler-Plymouth, Inc., 473 U.S. 614, 637 (1985) ("[S]o long as the prospective litigant effectively may vindicate its statutory cause of action in the arbitral forum, the statute will continue to serve both its remedial and deterrent function.").

460. See supra notes 180-205 and accompanying text (discussing the interpretation of Concepcion in Am. Express).
} 
preemption principles. That distinction appears to be important. In the federal/state situation, the Supremacy Clause mandates that a court's task is to give effect to federal policy, assuming a conflict exists. In the federal/federal situation, a court has no such constitutional mandate. Moreover, obstacle preemption resolves the conflict determining whether state law impedes the purposes and objectives underlying federal law. Indeed, the obstacle preemption analysis is grounded on the premise that Congress sought to eliminate states' discrimination against arbitration. Why should obstacle preemption principles prevent Congress from discriminating against arbitration if Congress seeks to do so?

Despite the dissimilar analytical framework in which Concepcion was decided, courts have been grappling with difficult questions about Concepcion's spillover effect on federal statutory and common law restrictions on arbitration. While some courts have held that Concepcion has nothing to say about federal common law, ${ }^{461}$ many more concluded that Concepcion applied with almost equal force in a federal/federal situation to displace rules interfering with the informality, efficiency, reduced costs, and speed of arbitration. ${ }^{462}$ The Supreme Court's decision in American Express came out decidedly in favor of a broad reading of Concepcion, to the point of saying that Concepcion was almost dispositive in a case that had nothing to do with state law preemption. ${ }^{463}$ While it may be too soon to say that the federal vindication of rights doctrine is dead, courts will struggle to apply the cabined vindication of rights analysis in an effective manner in the post-Concepcion, post-American Express world.

461. See, e.g., Raniere v. Citigroup Inc., 827 F. Supp. 2d 294, 310 (S.D.N.Y. 2011) (holding that Concepcion "addressed only whether a state law rule ... was preempted by the FAA," which "in no way alters" decisions based on "federal arbitral law"), rev'd on different grounds, $2013 \mathrm{WL}$ 4046278 (2d Cir. Aug. 12, 2013).

462. See, e.g., Coneff v. AT \& T Corp., 673 F.3d 1155, 1158-59 (9th Cir. 2012) (“Although Plaintiffs argue that the claims at issue in this case cannot be vindicated effectively because they are worth much less than the cost of litigating them, the Concepcion majority rejected that premise."); Knutson v. Sirius XM Radio Inc., No. 12CV418 AJB (NLS), 2012 WL 1965337, at *5 (S.D. Cal. May 31, 2012) (citing Concepcion's finding that unrelated policy concerns such as lack of incentive for customers to vindicate their rights "cannot undermine the FAA" while rejecting plaintiff"s argument that courts may only require the arbitration of statutory rights if litigants have the financial means to effectively vindicate those rights); Jasso v. Money Mart Express, Inc., 879 F. Supp. 2d 1038, 1045 (N.D. Cal. 2012) ("[T] based upon state law versus federal 'substantive law of arbitrability' was not viable." (quoting In re Am. Express Merchants' Litig., 667 F.3d 204, 212 (2d Cir. 2012))).

463. See Am. Express Co. v. Italian Colors Rest., 133 S. Ct. 2304, 2312 (2013) (“Truth to tell, our decision in [Concepcion] all but resolves this case."). 


\section{A. Consequences for Federal Law Hostile to Arbitration}

Concepcion largely has undermined the vindication of statutory rights rationale as it relates to state law claims, because a state law may "conflict with the FAA even if it is desirable for unrelated purposes." The Court in American Express showed its distaste for this federal common law principle that "originated as dictum" and which, on several previous occasions, the Court "declined to apply ... to invalidate the arbitration agreement at issue." 465 More significant than this rhetoric, however, American Express appears to have substantially limited this principle's application in the federal context as well.

The plaintiff in American Express had argued that an arbitration clause was not enforceable because the cost of pursuing its federal antitrust claim without a class action would indisputably cost more than any potential recovery, and thus, under Mitsubishi and Randolph, the plaintiff could not vindicate its federal statutory rights in the arbitral forum. ${ }^{466}$ The Court soundly rejected the argument, reasoning that "the fact that it is not worth the expense involved in proving a statutory remedy does not constitute the elimination of the right to pursue that remedy." for federal claims, then, "the FAA's command to enforce arbitration agreements trumps any interest in ensuring the prosecution of low-value claims." 468

The Court thus appears to have limited the effective vindication principle to the facts of Mitsubishi and Randolph. Mitsubishi only addressed the specific situation when "choice-of-forum and choice-of-law clauses operate[] in tandem as a prospective waiver of a party's right to pursue statutory remedies for antitrust violations ...."469 And, in Randolph, the Court merely addressed the issue whether a claimant could "effectively vindicat[e] her federal statutory rights" given her allegation that she risked "large arbitration costs," i.e., a filing fee, arbitrator fee, and other administrative fees, by bringing a claim in arbitration. ${ }^{470}$ While American Express reiterated the federal vindication of rights principle, the Court extrapolated from Mitsubishi only that an arbitration

\footnotetext{
464. See supra notes 298-456 and accompanying text (discussing the impact of Concepcion on state law).

465. Am. Express, 133 S. Ct. at 2310.

466. Id.

467. Id. at 2311 .

468. Id. at 2312 n.5.

469. Mitsubishi Motors Corp. v. Soler Chrysler-Plymouth, Inc., 473 U.S. 614, 637 n.19 (1985).

470. Green Tree Fin. Corp.-Ala. v. Randolph, 531 U.S. 79, 90 \& n.6 (2000).
} 
agreement could not expressly "forbid" or "eliminate" a party's right to pursue a federal statutory remedy. ${ }^{471}$ The Court even left open the question of whether Randolph had continuing validity by noting that "perhaps" the filing and administrative fees of arbitration could be "so high as to make access to the forum impracticable." 472 In other words, the effective vindication doctrine as articulated in American Express protects the right to pursue a federal claim, but not to ensure that pursuing the claim is "worth the expense." 473

In deciding whether these federal common law principles remain viable post-Concepcion, one must remember that Concepcion is part of a larger trend under which contrary federal laws trump the FAA only if those laws present an "irreconcilable conflict" with the purposes of the FAA. ${ }^{474}$ Thus, at the same time that the Court increasingly requires express contractual or statutory authority to deviate from the ideals of the FAA, the Court has been marginalizing the force of the common law effective vindication of rights doctrine.

Just a year before Concepcion, the Court in Stolt-Nielsen vacated an arbitration award because the arbitrator "manifestly disregarded" the law by allowing class actions when the agreement was "silent" on that issue, i.e., in the absence of express contractual authority. ${ }^{475}$ Echoing the subsequent discussion in Concepcion, the Court held that because class action procedures fundamentally "change[] the nature of arbitration," they could not have been implicit in the parties' agreement to arbitrate. ${ }^{476}$ In other words, Stolt-Nielsen appears to have expanded the meaning of "manifest disregard of the law" even to preclude arbitral decisions that conflict with what the Court considers the fundamental attributes of arbitration (and thus conflict with the FAA), absent unmistakably clear intent of the parties.

Just as the FAA's policies control if the parties have not clearly spoken on an issue, so too do the FAA's policies control absent unmistakably clear congressional intent. In January 2012, in CompuCredit Corporation v. Greenwood, ${ }^{477}$ the Court held that the Credit Repair

471. See Am. Express, 133 S. Ct. at 2310-11 ("[T]he fact that it is not worth the expense involved in proving a statutory remedy does not constitute the elimination of the right to pursue that remedy.").

472. Id. (citing Randolph, 531 U.S. at 90).

473. Id. at 2311 .

474. Shearson/Am. Express, Inc. v. McMahon, 482 U.S. 220, 239 (1987); see also Randolph v. Green Tree Fin. Corp.-Ala., 244 F.3d 814, 818 (11th Cir. 2001).

475. Stolt-Nielsen S.A. v. AnimalFeeds Int'l Corp., 559 U.S. 662, 686 (2010).

476. Id. at 685 .

477. 132 S. Ct. 665 (2012). 
Organizations Act (CROA) does not preclude arbitration because "the CROA is silent on whether claims under the Act can proceed in an arbitrable forum ...."478 This, in spite of the CROA's mandate that a credit repair organization disclose the following: "You have a right to sue a credit repair organization that violates the Credit Repair Organization Act." $" 479$ Thus, CompuCredit and Stolt-Nielsen provide clear support for one court's recent holding that the CROA does not authorize class arbitrations, despite certain provisions in the CROA such as right to punitive damages in class actions and the CROA's non-waiver provision which states that "'any waiver' of 'any protection provided by' the Act is void . ..."480 The Supreme Court did suggest in dicta, however, that express statutory authority could override the FAA's presumption in favor of arbitration. ${ }^{481}$

American Express took another clear step in this direction. Citing CompuCredit, the Court stated that the FAA compelled the enforcement of arbitration agreements for disputes that raise federal claims, "unless the FAA's mandate has been 'overridden by a contrary congressional command." "482 In other words, the Court requires Congress to clearly evince its intent to deviate from the FAA's policies or the fundamental attributes of arbitration, even in passing other federal statutes in the pursuit of other federal policies. The Court first considered whether Congress had clearly spoken on the issue in American Express, i.e., whether the antitrust laws showed Congress's intention to preclude a waiver of a class action procedure in antitrust claims; but as is often the case (especially with statutes passed well before the modern age of consumer arbitration), no Congressional language on point was found. ${ }^{483}$ Admittedly, the Court stated that its "finding of no 'contrary congressional command'

478. Id. at 673.

479. 15 U.S.C. $\$ 1679$ c(a) (2012).

480. King v. Capital One Bank (USA), N.A., No. 3:11-CV-00068, 2012 WL 5570624, at *9 (W.D. Va. Nov. 15, 2012).

481. See CompuCredit Corp. v. Greenwood, 132 S. Ct. 665, 672 (2012) (noting federal statutes that expressly override the FAA's presumption in favor of arbitration); see, e.g., 7 U.S.C. § $26(\mathrm{n})(2)$ (2012) ("No predispute arbitration agreement shall be valid or enforceable, if the agreement requires arbitration of a dispute arising under this section."); 15 U.S.C. § 1226(a)(2) (2012) ("Notwithstanding any other provision of law, whenever a motor vehicle franchise contract provides for the use of arbitration to resolve a controversy arising out of or relating to such contract, arbitration may be used to settle such controversy only if after such controversy arises all parties to such controversy consent in writing to use arbitration to settle such controversy."); cf. 12 U.S.C. § 5518(b) (2012) (granting authority to the newly created Consumer Financial Protection Bureau to regulate predispute arbitration agreements in contracts for consumer financial products or services).

482. Am. Express Co. v. Italian Colors Rest., 133 S. Ct. 2304, 2309 (2013) (quoting CompuCredit, 132 S. Ct. at 668-69).

483. Id. at $2309-10$ 
does not end the case." ${ }^{484}$ But by so narrowly construing the effective vindication principle as to prevent an arbitration agreement that flatly "forbids" or "eliminates" the assertion of a federal statutory right, but not the myriad other devices that could have the same effect, ${ }^{485}$ for all intents and purposes the Court ended its analysis when it found no "contrary congressional command." 486

Considering the Court's push to permit deviation from the FAA's purposes in the federal context only when there is clear contractual or statutory authority to support it, it is no wonder that the American Express majority was loath to apply the "judge-made" effective vindication principle to deviate from the "fundamental attributes of arbitration." 487 Given the level of statutory specificity required to deviate from such ideals under CompuCredit and the minimal protections afforded by the effective vindication principle under American Express, courts facing a potential conflict among federal laws will, as a default, pursue the purposes of the FAA to the detriment of other federal goals in the absence of congressional action.

\section{B. Recurring Federal Conflicts Issues}

\section{Class-Wide Arbitration}

Consistent with Randolph and Mitsubishi, a number of federal circuits have held that class action waivers could be invalidated if they prevented a prospective litigant from vindicating his or her federal cause of action. ${ }^{488}$ However, after Concepcion and more clearly in American Express, class arbitration cannot be required in the absence of express congressional authorization. ${ }^{489}$ One might argue that class arbitration could

\footnotetext{
484. Id. at 2310 .

485. See id. at 2314 (Kagan, J., dissenting) (citing various examples of "alternatives" to "baldly exculpatory provisions" that "would have the identical effect").

486. Id. at $2310-11$.

487. Id. at 2310, 2312.

488. See, e.g., In re Cotton Yarn Antitrust Litig., 505 F.3d 274, 285 (4th Cir. 2007) (“[I]f a party could demonstrate that the prohibition on class actions likely would make arbitration prohibitively expensive, such a showing could invalidate an agreement." (citation omitted)); Livingston v. Assocs. Fin., Inc., 339 F.3d 553, 557 (7th Cir. 2003) ("In the present case, the [plaintiffs] have not offered any specific evidence of arbitration costs that they may face in this litigation, prohibitive or otherwise, and have failed to provide any evidence of their inability to pay such costs ...."); Adkins v. Labor Ready, Inc., 303 F.3d 496, 503 (4th Cir. 2002) ("[Lead plaintiff] makes no showing of the specific financial status of any of the plaintiffs at the time this action was brought. He provides no basis for a serious estimation of how much money is at stake for each individual plaintiff.").

489. Am. Express, $133 \mathrm{~S}$. Ct. at 2309 ("No contrary congressional command requires us to reject the waiver of class arbitration here.").
} 
be required in certain circumstances under the effective vindication principle, even after American Express. We address this argument in the next section.

\section{Prohibitive Arbitration Costs}

Outside the class action context, courts have held under Mitsubishi and Randolph that prohibitive arbitration costs may prevent a party from effectively vindicating his federal statutory rights in arbitration, thereby rendering an arbitration agreement or some part thereof unenforceable. ${ }^{490}$ On the "costs" side of the ledger, courts have considered whether filing fees, arbitrator fees, and other administrative fees, as well as attorneys' fee splitting clauses, result in prohibitive costs. ${ }^{491}$ On the income side of the ledger, courts would consider evidence of the party's salary or other assets. Similarly, a party seeking to bring a claim as a member of a class could argue that the costs of bringing bilateral arbitration are so high as to also have the effect of preventing the vindication of the party's federal statutory rights.

American Express left open the question whether a Randolph-type claim that prohibitive arbitration costs, like "filing and administrative fees," continue to serve as a basis for invalidating an arbitration agreement under the effective vindication principle. ${ }^{492}$ However, the Court rejected the plaintiff's claim that it could not vindicate its federal rights because the cost of pursuing an antitrust claim in bilateral arbitration exceeded any potential recovery, on the grounds that "the fact that it is not worth the expense involved in proving a statutory remedy does not constitute the elimination of the right to pursue that remedy."493 This reasoning just as readily would appear to undermine a claim that the filing and other administrative fees of arbitration exceed the cost of recovery. One must bear certain administrative costs to file suit in court as in arbitration, and small value claims may not be worth the expense of pur-

490. See, e.g., Faber v. Menard, Inc., 367 F.3d 1048, 1054 (8th Cir. 2004) (requiring party seeking to avoid arbitration in ADEA case to present "specific evidence of likely arbitrators' fees," as defined by contract or estimated by reference to the issues in the case and arbitrator costs); Spinetti v. Serv. Corp. Int'1, 324 F.3d 212, 217 (3d Cir. 2003) (considering filing fees, other administrative fees, and arbitrator fees in determining whether arbitration costs would be prohibitively expensive); see also Green Tree Fin. Corp.-Ala. v. Randolph, 531 U.S. 79, 90-92 (2000).

491. Id. at 90 n.6.

492. See Am. Express Co. v. Italian Colors Rest., 133 S. Ct. 2304, 2310-11 (2013) (citing Randolph, 531 U.S. at 90) (writing that "perhaps" the effective vindication principle would cover such fees when they are "so high as to make access to the forum impracticable").

493. Id. at 2311 (citation omitted). 
suing the remedy. In any event, American Express, citing Concepcion, held that "the FAA's command to enforce arbitration agreements trumps any interest in ensuring the prosecution of low-value claims," whether grounded in state or federal law. ${ }^{494}$ Therefore, irrespective whether a party seeks to bring a claim as a member of a class, we do not expect a Randolph-type prohibitive arbitration costs argument to succeed to either prevent the enforcement of a class action waiver, or the arbitration clause as a whole.

\section{Limits on Statutory Damages}

Judicial decisions invalidating agreements to limit a claimant's rights to damages under its federal statutory cause of action ${ }^{495}$ would likely remain valid after Concepcion. Of course, class action arbitrations and the availability of statutory damages are similar in a key way-both are frequently necessary to give claimants sufficient incentive to prosecute their claims. That being so, the availability of statutory damages remain within the core holding of Mitsubishi that restrictions on statutory damages under the Sherman Act would be invalid to the extent that they defeated the remedial purposes of that law.

Additionally, American Express framed the effective vindication principle in terms of whether the challenged contract language acts as a "prospective waiver of a party's right to pursue statutory remedies." 496 A clause attempting to limit federal statutory damages would, at a minimum, directly interfere with a party's statutory remedies, and depending on the contract language, could operate as a prospective waiver of such remedies in entirety. Any such contract language would almost certainly run squarely into a "contrary congressional command." Furthermore, it is not evident how limiting damages serves the procedural ends of arbitration by lowering costs, decreasing formality, or increasing efficiency, which were touted as the fundamental attributes of arbitration under Concepcion's reasoning. Until the Court overrules Mitsubishi, the deci-

\footnotetext{
494. Id. at 2311.

495. Kristian v. Comcast Corp., 446 F.3d 25, 63 (1st Cir. 2006) (striking down arbitration clause that precluded award of attorney fees and costs to the prevailing party granted by federal and state statutes); Graham Oil Co. v. Arco Prods. Co., 43 F.3d 1244, 1248-49 (9th Cir. 1994) (holding arbitration agreement unenforceable where claimant forfeited (a) statutory rights to exemplary damages; (b) statutory rights to attorneys' fees; and (c) the more generous statute of limitations provided by law); Paladino v. Avnet Computer Techs., Inc., 134 F.3d 1054, 1062 (11th Cir. 1998) (holding an arbitration agreement unenforceable where it defeated the basic remedial purposes of Title VII).

496. Am. Express, 133 S. Ct. at 2310 (quoting Mitsubishi Motors Corp. v. Soler ChryslerPlymouth, Inc., 473 U.S. 614, 637 n.19 (1985) (emphasis added).
} 
sion still controls, ${ }^{497}$ and neither the language nor logic of Concepcion and American Express suggest that contractual limitations on federal statutory damages will be upheld.

\section{Restrictions on the Statute of Limitations}

By contrast, agreements providing for shorter statutes of limitations for federal claims may present a closer call. Many federal statutes expressly draft generous limitations periods for the benefit of civil plaintiffs. Limiting these periods may prevent the effective vindication of statutory rights. However, narrowing the statute of limitations promotes repose, reduces litigation costs, discourages evidence from becoming stale, reduces uncertainty, and improves the overall efficiency of dispute resolution. ${ }^{498}$ Moreover, invalidating agreements shortening limitations periods may disproportionately affect arbitration, thus presenting the biased application of generally applicable principles that the Concepcion majority mentioned. Thus, certain contractual restrictions on the statute of limitations may continue to be invalid, as some courts have held. ${ }^{499}$

\section{Impartiality and Lack of Mutuality}

Under pre-Concepcion federal common law, courts invalidated onesided arbitration agreements containing egregiously unfair rules or otherwise lacking mutuality, citing Randolph and Mitsubishi. ${ }^{500}$ As mentioned at the beginning of this Article, the Fourth Circuit's decision in Hooters is a particularly illustrative example of an arbitration agreement that was invalid under pre-Concepcion and pre-Randolph regimes due to the panoply of rules the Fourth Circuit considered one-sided.

In Hooters, the court invalidated an agreement between Hooters and

\footnotetext{
497. See Agostini v. Felton, 521 U.S. 203, 216 (1997).

498. See generally Tyler Ochoa \& Andrew Wistrich, The Puzzling Purposes of Statutes of Limitation, 28 PAC. L. J. 453 (1997) (exploring the policy considerations supporting statutes of limitation).

499. See Vicente v. Volkswagen of Tulsa, L.L.C., No. 12-CV-0318-CVE-TLW, 2012 WL 6115055 , at *3 (N.D. Okla. Dec. 10, 2012) ("Because the one-year limitation period contravenes the limitation of Title VII, the one-year limitation significantly diminishes a party's rights under Title VII. Defendant has agreed to waive the one-year limitation period. However, the Court finds that the one-year limitation period significantly diminishes plaintiff's statutory rights and is therefore unenforceable." (citations omitted)).

500. Murray v. United Food \& Commercial Workers Int'l Union, 289 F.3d 297, 303 (4th Cir. 2002) (holding that an arbitration agreement was unenforceable because the agreement drafted by the employer "placed control over the selection of the single arbitrator for employment disputes in the hands of [the] employer"); Hooters of Am., Inc. v. Phillips, 173 F.3d 933, 939 (4th Cir. 1999).
} 
its employee, which included the following provisions regarding arbitration: the employee was required to identify its legal and factual claims with specificity (including providing a list of its witnesses and testimony), but Hooters was free not to file any responsive pleadings, or provide notice of its defenses or witnesses; only Hooters could arbitrate matters not raised in the employee's claim; only Hooters could move for summary dismissal before a hearing; Hooters exercised complete control of creating the record of the proceedings; and finally, only Hooters could cancel the arbitration agreement with thirty days' notice, or seek vacatur of the award. The court concluded that " $[t]$ he Hooters rules when taken as a whole, however, are so one-sided that their only possible purpose is to undermine the neutrality of the proceeding." continuing viability of Hooters on the ground that the arbitration agreement at issue was so fundamentally unfair that it was incompatible with "fundamental attributes of arbitration."

Surprisingly, there is even a plausible case that Hooters may no longer be valid after Concepcion, despite its unusual facts. First, Hooters did not find that the arbitration agreement would undermine the plaintiff's federal statutory cause of action nor did the court apply the "effective vindication of statutory rights" test. Rather, the court pegged its analysis to Hooters' obligation to perform its contractual duty in "good faith," which purportedly entailed the "faithfulness to an agreed common purpose and consistency with the justified expectations of the other party." 502 To the extent that Randolph and Mitsubishi are the exclusive bases under federal common law to strike down arbitration agreements, and to the extent that those cases are limited to their facts, it arguably would be improper to rely on policy reasons grounded on the inchoate obligation to act in "good faith."

Second, it could be argued that striking down the agreement would impede the purposes underlying the FAA. Requiring the employee to set forth his or her claim with specificity allows the employer to assess whether it will be necessary to fight the claim or proceed to settlementrelieving one party of discovery and pleading obligations and reducing costs. Allowing one party to select the arbitrator improves efficiency by, for example, eliminating the possibility that both parties fight over arbitrator selection. Finally, invalidating agreements due to a lack of mutuality and "good faith" might be used disproportionately against arbitration

501. Hooters, 173 F.3d at 939.

502. Id. at 940 (citing RESTATEMENT (SECOND) OF CONTRACTS $§ 205 \mathrm{cmt}$ a (1981)). 
agreements, just as California courts have done in applying state unconscionability law. Should this happen, mutuality-based reasoning would likely become incompatible with the anti-discrimination prong of FAA preemption analysis. However, to the extent that such arguments might be made, at present, the courts are continuing to apply the principles set forth in Hooters and elsewhere to ensure access to a neutral arbitral forum. ${ }^{503}$

\section{CONCLUSION: CONCEPCION CONCEPTUALIZED}

This Article has systematically considered Concepcion's effect on state and federal restrictions on the arbitration process. Unlike several commentators, we conclude that Concepcion's effects are far-ranging in several dimensions.

First, under the most objective interpretation of Concepcion, the FAA preempts any state law that (1) prohibits outright the arbitration of a particular type of claim; (2) violates the FAA's anti-discrimination principle when the rule is more likely to be applied in a manner disfavoring arbitration; or (3) interferes with "fundamental attributes of arbitration"-informality, efficiency, reduced costs, and speed.

Second, Concepcion invalidates prior decisions that the FAA does not preempt certain state rules. In light of the three-prong test described in this Article, and taking Concepcion's reasoning at face value, the likely effect of Concepcion is as follows:

- The FAA may, as a general matter, preempt any type of state procedural law, and it is immaterial whether the law is classified as "procedural" or "substantive."

- The FAA preempts inconsistent state arbitration acts that regulate appeals from orders compelling or denying arbitration.

- The FAA preempts rules purporting to establish a discovery baseline, irrespective of whether the parties agreed to a different discovery baseline in arbitration.

- The FAA now preempts rules interfering with the confidentiality of arbitration proceedings.

503. See, e.g., Raglani v. Ripken Professional Baseball, No. CCB-12-3682, 2013 WL 1633053, at *6-7 (D. Md. Apr. 16, 2013) (invalidating arbitration agreement that "did not sufficiently guarantee a neutral forum" in arbitration). 
- The FAA preempts a greater number of rules that regulate the manner in which the parties may split costs.

- The FAA preempts a greater number of rules that regulate the forum in which arbitration may take place.

- Unconscionability as a defense still survives, but it is unclear what, if any, practical power it now has.

Third, Concepcion, as that decision was interpreted in American Express, pares back the federal policy grounds for refusing to arbitrate, including those rationales arising from the penumbras in Randolph and Mitsubishi. It is very likely that Randolph and Mitsubishi, while not overruled, are now greatly restricted in their application. And more than that, there is an exceedingly plausible case that state courts may not use Randolph and Mitsubishi to find arbitration agreements unconscionable under state law.

Finally, Concepcion may shift future litigation to a more fundamental - but to date unexplored-discussion of what arbitration "is" and whether our current understandings of arbitration are susceptible to evolution. As arbitration increasingly displaces litigation as the preferred method of dispute resolution, the "fundamental attributes of arbitration" will hopefully draw more careful attention from courts and commentators alike. Until that day arrives, the Supreme Court has spoken, and a tectonic shift in the law is now underway. 